\title{
Technical Evaluation of the Safe Transportation of
Waste Containers Coated Safe Transportation of
Waste Containers Coated With Polyurea
}

Prepared for the U.S. Department of Energy Assistant Secretary for Environmental Management

Project Hanford Management Contractor for the

U.S. Department of Energy under Contract DE-AC06-96RL13200

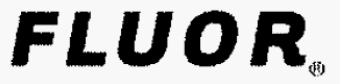

P.O. Box 1000

Richland, Washington 
HNF-32146

Revision 0

EDC \#: HNF-EDC-07-33242

\section{Technical Evaluation of the Safe Transportation of Waste Containers Coated With Polyurea}

Document Type: TR

Program/Project: WSD

T. S. Vail

Fluor Hanford, Inc.

Date Published

March 2007

Prepared for the U.S. Department of Energy

Assistant Secretary for Environmental Management

Project Hanford Management Contractor for the

U.S. Department of Energy under Contract DE-AC06-96RL13200

\section{FLUOR.}

P.O. Box 1000

Richland, Washington

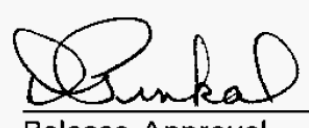

Release Approval

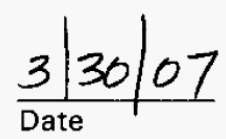

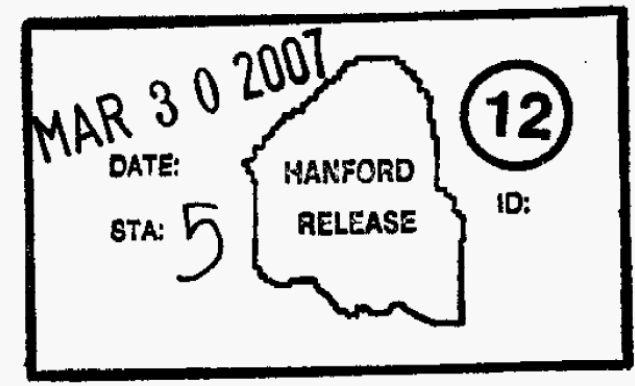

Release Stamp

\section{Approved for Public Release;}

Further Dissemination Unlimited 
HNF-32146

Revision 0

TRADEMARK DISCLAIMER

Reference herein to any specific commercial product, process,

or service by trade name, trademark, manufacturer, or

otherwise, does not necessarily constitute or imply its

endorsement, recommendation, or favoring by the United

States Government or any agency thereof or its contractors or subcontractors.

This report has been reproduced from the best available copy.

Printed in the United States of America

Total Pages: $\quad 66$ 


\section{TABLE OF CONTENTS}

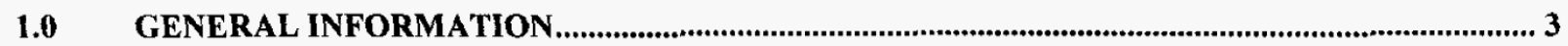

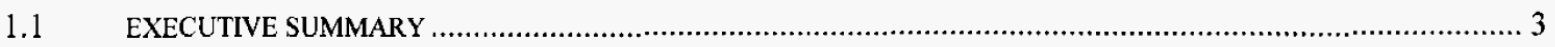

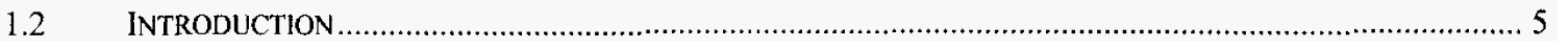

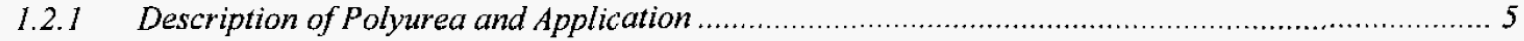

1.2.2 Other information Including Materials Specifications and Product Data ......................................... 6

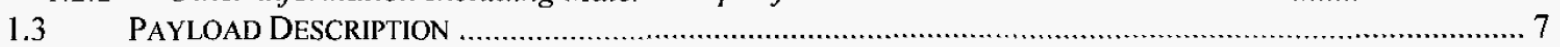

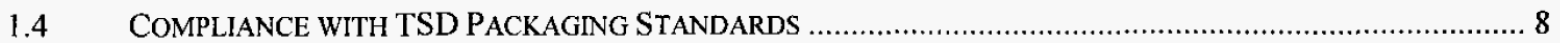

1.4.1 Statement of Compliance to TSD Packaging Standards ................................................................ 8

2.0 SUMMARY OF EVALUATION ............................................................................................................ 9

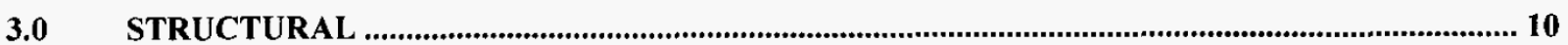

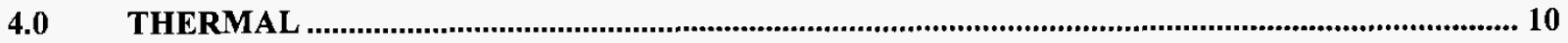

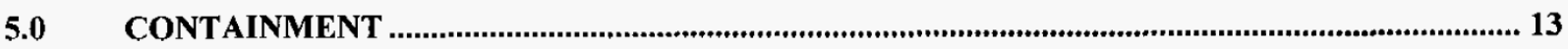

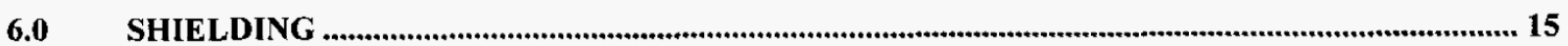

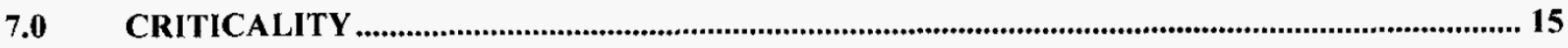

8.0 GAS GENERATION........................................................................................................................... 16

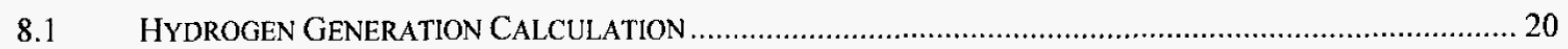

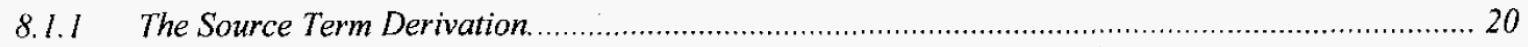

8.1.2 Volume (external) of 55-gal drum (from Myers Container Corporation) ........................................ 21

8.1.3 Volume (external) of 55-gal drum with polyurea coating (from Myers Container Corporation)....... 22

8.1.4 Density of Polyurea: ............................................................................................................ 22

8.1.5 Volume and mass of polyurea after it is applied to the drum: ...................................................... 23

8.1.6 Volume of 85-gal drum (Myers Container Corporation).............................................................. 23

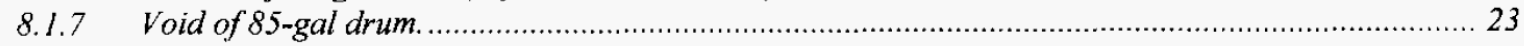

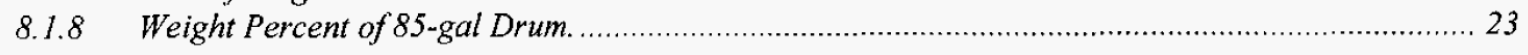

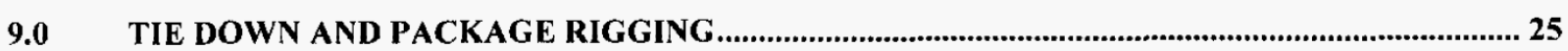

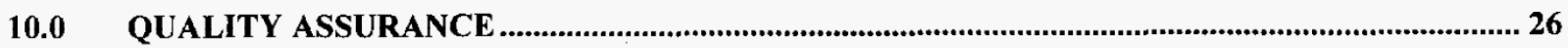

11.0 ACCEPTANCE TESTS AND MAINTENANCE PROGRAM REVIEW .......................................... 26

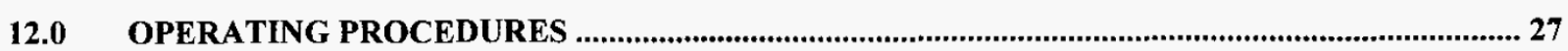

$13.0 \quad$ REFERENCES ...................................................................................................................................... 28

APPENDIX A ENVIROLASTIC AR425 DATA SHEET AND INSTACOTE INFORMATION DATA ..... A-1

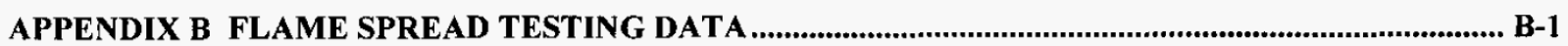

APPENDIX C HYDROGEN GAS GENERATION CALCULATIONS ........................................................... C-1 
HNF-32146, Revision 0

\section{List of Tables}

Table 4.1. Results of the Thermal Evaluations in HNF-2209 and HNF-SD-TD-SARP-004 ..... 12

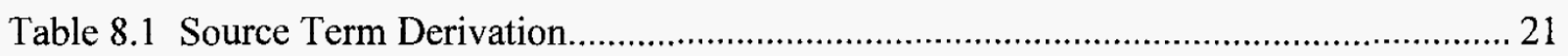

Table 8.2. Weight Fraction of the 85 gal Overpack for Input to Radcalc................................... 24

Table 8.3. Weight Fraction of the 85 gal Overpack w/o Polyurea for Input to Radcalc ............. 25

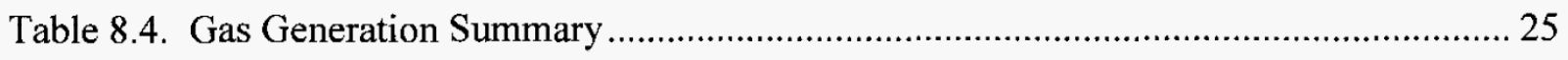


HNF-32146, Revision 0

\subsection{GENERAL INFORMATION}

\subsection{EXECUTIVE SUMMARY}

This technical report is to evaluate and establish that the transportation of waste containers (e.g. drums, wooden boxes, fiberglass-reinforced plywood (FRP) or metal boxes, tanks, casks, or other containers) that have an external application of polyurea coating between facilities on the Hanford Site can be achieved with a level of onsite safety equivalent to that achieved offsite. Utilizing the parameters, requirements, limitations, and controls described in the DOE/RL-200136, Hanford Sitewide Transportation Safety Document (TSD) and the Department of Energy Richland Operations (DOE-RL) approved package specific authorizations (e.g. Package Specific Safety Documents (PSSDs), One-Time Requests for Shipment (OTRSs), and Special Packaging Authorizations (SPAs) this evaluation concludes that polyurea coatings on packages does not impose an undue hazard for normal and accident conditions

The transportation of all packages on the Hanford Site must comply with the transportation safety basis documents for that packaging system. Compliance with the requirements, limitations, or controls described in the safety basis for a package system will not be relaxed or modified because of the application of polyurea. The inspection criteria described in facility/projects procedures and work packages that ensure compliance with Container Management Programs and transportation safety basis documentation dictate the need to overpack a package without consideration for polyurea.

This technical report reviews the transportation of waste packages coated with polyurea and does not credit the polyurea with enhancing the structural, thermal, containment, shielding, criticality, or gas generating posture of a package. Facilities/Projects Container Management Programs must determine if a container requires an overpack prior to the polyurea application recognizing that circumstances newly discovered surface contamination or loss of integrity may require a previously un-overpacked package to subsequently require overpacking. Therefore, the polyurea coating can not be credited to avoid the need to overpack a package or enhance the transportation safety of a structurally sound package that has polyurea on the exterior.

Polyurea is a 2-part, spray-applied, aromatic coating system that will provide a barrier against environmental conditions and function as a fixative or prevention for surface contamination. An application of the polyurea compound will protect containers from further degradation by inhibiting corrosion. It is resistant to moisture intrusion, provides environmental protection, etc, and thereby helping to minimize the potential for the spread of radioactive contamination. Cured polyurea is $100 \%$ solids, i.e. no volatile organic compounds (VOCs) are given off. The propensity for isocyanate sensitivity requires special exposure controls and personal protective equipment (PPE) during the application; however, these considerations do not extend to the handling of cured polyurea during transportation operations.

The transportation safety basis documents that describe the requirements, limitations, and controls for the transportation of packages address the frequency and radiological dose consequences of postulated accidents that include collision, collision with fire, and hydrogen deflagration. Containers with polyurea on the exterior surface or packages coated with polyurea 


\section{HNF-32146, Revision 0}

that are in an overpack do not alter the frequency of transportation accidents. Polyurea does not contribute to the radiological source term in a package so the radiological dose consequence of accidents as analyzed in the transportation safety basis documents can not be impacted by the presence of polyurea on or in a package.

The performance of polyurea coatings during a fire was investigated. The Manufacture's Data Sheet, for a polyurea coating marketed by The Sherwin Williams Co. under the name of Envirolastic ${ }^{(B)}$ AR425 is presented in Appendix A. The Surface Burning Characteristics (ASTM E84) testing that was performed at a 20-mil thickness measured a flame spread rating of 10 and smoke density of 35 for the polyurea material. Even though the Envirolastic AR425 polyurea coating material may be applied at a nominal 30-250 mil thickness the expected thickness used at Hanford is 50-150 mils. ASTM E84 flame spread testing done at a 500-mil thickness for a similar coating material (Instacote SE FR®) resulted in a flame spread rating of 20 and smoke density of 115 (Appendix B). These flame spread ratings are low such that they are considered a Class A building material by the National Fire Protection Association (NFPA) and according to the Solid Waste Operations Complex (SWOC) Fire Hazards Analysis (FHA) Attachment 6, do not drip or fall off when exposed to flames.

The collision with fire accident scenario for transportation is evaluated with the containers, payload, and material at risk (MAR) fully engulfed in the fire. The damage ratio (DR), Airborne Release Fraction (ARF), and Respirable Fraction (RF) are consistent with the definition of "packaged waste" in the Hanford Safety Analysis and Risk Assessment Handbook (SARAH), HNF-8739, Table 3.5. SARAH describes this material as generally combustible contaminated waste in plastic bags or taped plastic bags or in pails, drums, and waste boxes. The propagation of the fire will be caused primarily by the combustible waste materials and will not be augmented by the polyurea. Also, the polyurea is judged to provide a negligible contribution to the smoke density caused by the burning plastics, tape, wood, and other cellulosic and synthetic materials. A flame spread rating of 25 is equivalent to a Class A building material, so for comparison, regular lumber ranges from Western Larch with a flame spread of 45 to yellow poplar with a flame spread between 170-185 and hardwood plywood like $3 / 4$ " birch with High Density Veneer Core has a flame spread of 114 (source American Forest \& Paper Association, Inc.). The examples of polyurea discussed in this report, i.e. Envirolastic ${ }^{\circledR}$ AR425, Appendix A and Instacote SE FR(B), Appendix B are both Class A building materials. A fire involving polyurea can be extinguished utilizing standard fire suppression materials, methods, and practices, such as full face shield and self contained breathing apparatus, water, foam, dry chemicals or $\mathrm{CO}_{2}$ (MSDS \#063396). The fire hazard associated with polyurea is about the same as fiberglass (MSDS \#13659) and cellulosic materials.

Hydrogen generated by polyurea applied to the exterior of a retrieved or newly filled waste package can not contribute to or impact the hydrogen content inside the package unless that package is placed into an overpack. The calculations determined that the unvented void of the

\footnotetext{
${ }^{8}$ Envirolastic is a registered trademark of the Sherwin-Williams Company

(B) Instacote SE FR is a registered trademark of Instacote, Inc. 
85 -gal drum containing a 55-gal drum with $500 \mathrm{~g}$ of TRU with $12 \%{ }^{240} \mathrm{Pu}$ contains $1.9 \% \mathrm{H}_{2}$ and without polyurea $0.026 \% \mathrm{H}_{2}$. For comparison purposes the hydrogen gas calculations for an 85 gal drum containing a 55-gal container with $200 \mathrm{~g}$ of TRU with $12 \%{ }^{240} \mathrm{Pu}$ contains $0.78 \% \mathrm{H}_{2}$ and without polyurea $0.01 \% \mathrm{H}_{2}$. These Radcalc, Section 8.0 and Appendix C calculations indicate the hydrogen gas concentration in the void space of an 85 gallon overpack containing a 55 gallon drum that has an exterior fully coated with polyurea modeled as High Density Polyethylene (HDPE) enclosed for 5 years does not reach the lower flammable limit for hydrogen.

\subsection{INTRODUCTION}

Waste processing activities require the storage and ultimately the movement of packages that are structurally sound, but have potentially degraded confinement layers or surface contamination that could have come from a different container. To mitigate the prospect of spreading contamination during storage, handling, processing, or transportation these packages are currently inserted into an overpack. The overpack provides a confinement barrier to the spread of radioactive contamination, but the supplemental structural strength is unnecessary for containers that satisfy the containment and structural requirements established in the DOE/RL2001-36, Hanford Sitewide Transportation Safety Document (TSD) and its packaging authorizations.

The application of polyurea, when applied properly, does not prohibit a package from being inserted into an overpack for shipping, so it can be used on drums, wooden boxes, fiberglassreinforced plywood (FRP) or metal boxes, tanks, casks, or other containers. Polyurea does not contain radioactive isotopes so does not contribute to the radiological source term confined in the package. The polyurea coating is not credited with providing additional structural strength so the original container or its overpack must meet the conditions of the transportation safety basis documents for sound integrity. The application of polyurea is not credited with reducing the radiological dose consequences from postulated accident scenarios as analyzed in the TSD. Therefore, source term limits consistent with the (DOE-RL) approved package specific authorizations shall be implemented without change.

\subsubsection{Description of Polyurea and Application}

Polyurea is a 2-part, spray-applied, aromatic coating system that will provide a confinement barrier against environmental conditions for penetrations that are not readily visible and function as a fixative for surface contamination. This type of product is marketed by several companies with multiple formulations; however the selected product must have a flame spread of less than or equal to 25 according to HNF-21239, SWOC Fire Hazards Analysis.

Application of the polyurea compound will provide weatherization of boxes for outside storage, or to protect containers from further degradation, thereby helping to minimize the potential for the spread of radioactive contamination. Packages may or may not be sprayed with polyurea, but the Facilities/Projects Container Management Programs must determine if a container needs to be overpacked prior to the polyurea application. Therefore, the polyurea coating can not change the decision to place a package into an overpack. 
The transportation of all packages on the Hanford Site must comply with the Transportation Safety Basis Documents for that package. Compliance with the requirements, limitations, or controls described in the safety basis for a packaging system will not be relaxed or modified because of the application of polyurea. The coating may be used on waste drums, or other waste container types, such as metal boxes, plywood boxes, or fiberglass reinforced plywood (FRP) boxes.

Wood or FRP boxes coated with a polyurea spray will be treated the same as uncoated wood or FRP boxes. Special treatment like spacing or additional fire suppression is not warranted or required. Areas requiring patching shall use materials similar to those used in the original construction of the box. Wood or FRP boxes that are coated with a polyurea can be treated the same as those that are not coated from a fire hazard perspective (HNF-21239, Attachment 6).

Metal boxes that are coated with polyurea in accordance with ASTM E84 flame spread test that demonstrates a flame spread less than or equal to 25 can be treated the same as uncoated metal boxes. (HNF-21239, Attachment 6). The metal boxes are robust and a coating of polyurea will not significantly change their performance in a fire. Boxes shall be considered structurally sound prior to the application of a polyurea coating. The use of polyurea with a flame spread of less than or equal to 25 may be a facility requirement, however the postulated transportation fire accident scenario assumes a complete failure of all packages exposed to the fire accident.

\subsubsection{Other information Including Materials Specifications and Product Data}

Polyurea is a spray-applied, aromatic coating system. It is composed of a part A material (isophorone diisocyanate and polyoxypropyleneamine) and a part B material (diethyltoluendiamine, proprietary light stabilizer, proprietary polyetheramine, proprietary polyoxypropyleneamine, and carbon black). This material exhibits extreme toughness and elastomeric performance characteristics. The material can be applied to a variety of surfaces that are clean, dry, and in sound condition. It has the ability to encapsulate small or large areas of corrosion on a container, allowing normal handling while dramatically increasing its weather resistance for outside storage or reducing the risk of contamination spread. Also, after the polyurea application has cured it is $100 \%$ solid, i.e. no volatile organic compounds (VOCs) are given off (Appendix A). The drying schedule of polyurea to the touch and tack free is about 45 seconds, light traffic is 2 hours, and full cure, to achieve the maximum rated physical properties, is expected in 24 hours.

Polymer systems referred to as polyureas have certain characteristics suitable for rapid process applications. The major application is the Reaction Injection Molding (RIM) for automotive body panel part production. Certain characteristics of this technology that have proven useful for coating applications, include in part (Appendix A):

$>$ Fast, consistent reactivity and cure, reducing the likelihood for pockets of unreacted material.

$>$ Moisture and temperature insensitivity during processing, ambient air and surface temperatures are to be between $-28.9^{\circ} \mathrm{C}$ to $48.9^{\circ} \mathrm{C}\left(-20^{\circ} \mathrm{F}\right.$ and $\left.120{ }^{\circ} \mathrm{F}\right)$ with the maximum relative humidity of $80 \%$, so the range of ambient humidity and temperatures are favorable for use at Hanford.

$>$ Excellent physical properties / elastomeric qualities so will be extremely tough to 


\section{HNF-32146, Revision 0}

reasonable impacts and will generally return to its original shape upon low impact.;

$>$ Very low water absorption qualities, hydrolytically stable, so provides good separation of environmental moisture from the applied substrate, and extremely high waterproofing quality.

$>$ High thermal stability, maintains good physical properties over a wide temperature range $-40^{\circ} \mathrm{C}$ to $177^{\circ} \mathrm{C}\left(-40^{\circ} \mathrm{F}\right.$ to $\left.350^{\circ} \mathrm{F}\right)$ data for InstaCote.

$>$ Auto-catalytic, no solvents, the curing of polyurea does not require the evaporation of organic solvents.

$>$ High crack bridging so polyurea is able to cover small cracks and effectively maintains surface integrity over moving cracks up to $0.318 \mathrm{~cm}(0.125 \mathrm{in}$.$) .$

$>$ Very hard surface and high impact resistance.

$>$ Strong adhesion to a variety of surfaces provided the surface preparation complies with the manufactures recommendations.

$>$ High tear strength.

The Manufacture's Data Sheet, for a polyurea coating marketed by The Sherwin Williams Co. under the name of Envirolastic AR425 and informal communication from the manufacture of InstaCote is presented in Appendix A. The Surface Burning Characteristics (ASTM E84) testing that was performed at a 20 -mil thickness measured a flame spread rating of 10 and smoke density of 35 for the polyurea material. Even though the polyurea coating material will typically be applied at a nominal 50-150 mil thickness, ASTM E84 flame spread testing done at a 500-mil thickness for a similar coating material (Instacote SE FR) resulted in a flame spread rating of 20 and smoke density of 115 (Appendix B). These flame spread ratings are relatively low and while technically combustible, does not propagate flames, is self extinguishing, and does not drip or fall off when exposed to flames (HNF-21239, Attachment 6).

\subsection{PAYLOAD DESCRIPTION}

Polyurea is a coating sprayed on the outside of a container to enhance the contamination control of degraded or corroded containers. The transportation of all containers on the Hanford Site must comply with the Transportation Safety Basis Documents for those containers. Compliance with the requirements, limitations, or controls described in the safety basis for a packaging system will not be relaxed or modified because of the application of polyurea. It is expected that the benefits of the coating will be realized primarily for packages that are being retrieved from the LLBG; however, the scope of this report includes any packages located on the Hanford site that require transportation to or from any facility on the Hanford Site.

Polyurea can not add to, subtract from, or by its use redistribute the radioactive waste material that is placed inside a container. A consideration for the use of polyurea would be gross weight limits for both the container and conveyance. Even though an intended use of the polyurea coating provide environmental protection and function as a fixative of surface contamination, An additional objective is to minimize the need to overpack containers. However, the possibility that a coated package will require overpacking subsequent to the application of polyurea can not be ignored. Facility Container Management Programs that evaluate a package and conclude the container must be overpacked must not reverse the overpack decision based solely on the application of polyurea. 
The flame spread and smoke density testing is evaluated with respect to the transportation accident analysis in the TSD. The collision with fire accident scenario for transportation assumes the containers, payload, and material at risk (MAR) is fully engulfed in the fire. The damage ratio (DR), Airborne Release Fraction (ARF), and Respirable Fraction (RF) identified in the TSD Appendix G, Tables $2 \mathrm{a}$ and $2 \mathrm{~b}$ are consistent with the definition of "packaged waste" in the Hanford Safety Analysis and Risk Assessment Handbook (SARAH), HNF-8739, Table 3.5. SARAH describes this material as generally combustible contaminated waste in plastic bags or taped plastic bags or in pails, drums, and waste boxes. The propagation of the fire will be caused primarily by the combustible waste materials because the flame spread test data described in Appendix B supports conclusions that the polyurea is considered a Class A building material by the NFPA and according to the SWOC FHA Attachment 6, does not drip or fall off when exposed to flames. Also, the smoke density caused by the burning plastics, tape, wood, and other cellulosic and synthetic materials will not be significantly increased by the presence of polyurea which is conservatively determined to be about $9 \%$ of the mass (see Section 8.0 ). A fire involving polyurea can be extinguished utilizing standard fire suppression materials, methods, and practices, such as full face shield and self contained breathing apparatus, water, foam, dry chemicals or $\mathrm{CO}_{2}$. The fire hazard associated with polyurea is about the same as fiberglass (MSDS \#13659) and cellulosic materials. The inhalation of smoke and dust particles is a standard hazard associated with extinguishing fires.

\subsection{COMPLIANCE WITH TSD PACKAGING STANDARDS}

The transportation of all containers on the Hanford Site must comply with the transportation safety basis documents for that packaging system. Compliance with the requirements, limitations, or controls described in the safety basis for a package must not be relaxed or modified because of the application of polyurea. The inspection criteria described in facility/projects procedures and work packages that ensure compliance with Container Management Programs and transportation safety basis documentation will dictate the need to overpack a package. The addition of polyurea does not impact the compliance with normal transportation conditions (NTC) under DOE approved authorizations.

\subsubsection{Statement of Compliance to TSD Packaging Standards}

This technical report is to evaluate and establish that the transportation of waste containers (e.g. drums, wooden boxes, fiberglass-reinforced plywood (FRP) or metal boxes, tanks, casks, or other containers) that have an external application of polyurea coating between facilities on the Hanford Site can be achieved with a level of onsite safety equivalent to that achieved offsite. The use of polyurea does not compromise the parameters, requirements, limitations, and controls described in the TSD and the DOE-RL approved package specific authorizations (e.g. Package Specific Safety Documents (PSSDs), One-Time Requests for Shipment (OTRSs), etc.). The TSD Section 6.1.1.3, provides that when full compliance with U.S. Department of Transportation (DOT) regulations or DOT-equivalent packaging for radioactive materials cannot be achieved for onsite shipments because of technical or economic conditions, a risk-based method for demonstrating an acceptable "equivalent" level of safety will be implemented, i.e. "risk based". Requirements for risk based packages are developed to result in a package that under Site conditions will produce radiological and toxicological risk equivalent to an offsite package subjected to regulatory-established tests and conditions. 
Polyurea applied to a package is not credited with enhancing the structural, thermal, containment, shielding, criticality, or gas generating posture of a package. Compliance with the requirements, limitations, or controls described in the safety basis for a package must not be relaxed or modified because of the application of polyurea. The inspection criteria that ensure compliance with Container Management Programs and transportation safety basis documentation are described in facility/project procedures and work packages.

\subsection{SUMMARY OF EVALUATION}

Utilizing the parameters, requirements, limitations, and controls described in the TSD and the DOE-RL approved package specific authorizations (e.g. Package Specific Safety Documents (PSSDs), One-Time Requests for Shipment (OTRSs), and Special Packaging Authorizations (SPAs) this evaluation concludes that polyurea coatings on containers does not impose an undue hazard for normal- and accident conditions. The Hanford Site Solid Waste Acceptance Criteria, HNF-EP-0063, Section 2.13.2 states that "Outer containers shall be in good condition, with no visible cracks, holes, dents, bulges, pit or scale corrosion, or other damage that could compromise container integrity (WAC 173-303-630). Minor external surface rust that can be sanded or brushed off will be acceptable. Containers having some pit or scale corrosion could be acceptable for storage provided the integrity of the container is confirmed. Polyurea coated containers must have a Flame Spread rating of 25 or less for acceptance into CWC." The WRAP and T Plant have similar requirements for exterior coatings. Facility operating procedures are required to identify criteria by which the "good condition" of containers are determined and, if not in "good condition" are overpacked in order to ensure the outer container is in "good condition".

The application of polyurea to the exterior of a package that is to be overpacked or a piece of equipment that must be overpacked can not change the decision to overpack the waste material. The polyurea application to a package is expected to mitigate the possibility of spreading contamination during storage, handling, or processing. Containment/confinement requirements applicable under the TSD/PSSDs must be met as specified and in a manner which is completely independent of the presence of the polyurea.

The coating may be used on waste packages such as waste drums, metal boxes, plywood boxes, or fiberglass reinforced plywood (FRP) boxes. Polyurea applied to a package is not credited with enhancing the structural, thermal, containment/confinement, shielding, criticality, or gas generating posture of a package. Packages that have a polyurea coating on the exterior can be placed into an overpack or other package and will not affect the safe transportation of that package, provided all limits and controls established for that package in the DOE-RL approved authorizations are complied with.

Polyurea can not add to, subtract from, or by its use redistribute the radioactive waste material that is placed inside a package. A consideration for the use of polyurea would be gross weight limits for both the container and conveyance, but the gross weight limits are not derived from, modified, or revised because of the polyurea coating. Even though the intended use of the polyurea coating is to minimize the spread of radioactive contamination, this evaluation can not ignore the possibility that a coated package will require overpacking subsequent to the

application of polyurea. For example, surface contamination from a source external to the coated package can not be ruled out. Facility/Project Container Management Programs must determine 
if a container needs to be overpacked prior to the polyurea application and the polyurea coating must not affect the ability to place a package or piece of equipment into an overpack.

The collision with fire accident scenario for transportation assumes the containers, payload, and MAR is fully engulfed in the fire. The packaged waste material described in SARAH is generally combustible contaminated waste in plastic bags or taped plastic bags or in pails, drums, and waste boxes. The propagation of the fire will be caused primarily by the combustible waste materials because the flame spread described in Appendix B supports conclusions that the polyurea is a Class A building material with relatively low fire propagation potential. Also, the smoke density of the fire is primarily caused by the burning plastics, tape, wood, and other cellulosic materials and will not be significantly increased by the presence of polyurea, (Appendix B).

The only control derived from this evaluation specific and unique to the polyurea coating is that it must be fully cured prior to transportation activities. The cure time is generally 24 hours according to the Instacote SE FR and Envirolastic AR 425 information; , however, the appropriate cure time for other polyurea formulations must be determined prior to acceptance for transportation activities. All other requirements, limitations, and controls described in the DOERL approved package specific authorizations (e.g. PSSDs, OTRSs, etc.) are not impacted in anyway by the application of polyurea.

\subsection{STRUCTURAL}

Acceptable performance of waste packages containing radioactive waste to maintain containment and structural integrity under normal transportation conditions (NTC) in accordance with DOE/RL-2001-36, Section 6.1.1.3 are demonstrated by a combination of physical testing and engineering analysis. As stated in the TSD, when DOT-equivalent packaging for radioactive materials cannot be achieved for onsite Hanford shipments a risk-based method, i.e. engineering analysis, may be implemented.

The authorization to transport a package on the Hanford Site is established with the approval of safety basis documentation for the specific package. The safety basis documentation includes the analysis of the structural integrity imposed stresses during normal- and accident-conditions for each package. This evaluation does not credit the polyurea coating with contributing to the integrity of any container. The performance of risk based packages is not credited so the application of polyurea does not affect the failure, even though the physical properties of polyurea might provide some low impact protection. The weight of the package due to the polyurea coating shall not exceed the limitation for the package or conveyance as defined in the safety basis documentation for that package since the gross weight limits are not derived from, modified, or revised because of the polyurea coating.

\subsection{THERMAL}

The purpose of the thermal evaluation is to determine the performance of packages under normal- and accident- conditions of transportation. The contents of the package are various radioactive materials with a total decay heat load that varies with the source term and package as evaluated in the DOE-RL authorizations for the specific package. 


\title{
HNF-32146, Revision 0
}

The TSD Section 6.5.2.4.4 "Thermal Limitations" states that "(a) Heat generated within the package by the radioactive contents will not, during conditions normally incident to transport, affect the integrity of the package; and (b) Temperature of the accessible external surfaces of the loaded package will not, assuming still air in the shade at an ambient temperature of $38^{\circ} \mathrm{C}$ $\left(100^{\circ} \mathrm{F}\right)$, exceed:

(1) $50^{\circ} \mathrm{C}\left(122^{\circ} \mathrm{F}\right)$ in other than an exclusive-use shipment; or

(2) $85^{\circ} \mathrm{C}\left(185^{\circ} \mathrm{F}\right)$ in an exclusive-use shipment.

\section{The TSD Section B.3.8.1 states}

\begin{abstract}
"Based on climatological data reported from 1912 to 1980 in WHC-SD-TP-RPT-004, Environmental Conditions for On-Site Hazardous Materials Packages, the highest recorded temperature on the Hanford Site is $46^{\circ} \mathrm{C}\left(115^{\circ} \mathrm{F}\right)$. Consequently, site-specific determination of maximum allowable package external temperature is based on a more severe condition than for the regulations."
\end{abstract}

The polyurea spray systems must be processed through high pressure, high temperature impingement mix type equipment in order to achieve the optimum atomization and qualities for a coating. The polyurea material needs to be between $66^{\circ} \mathrm{C}\left(150^{\circ} \mathrm{F}\right)$ and $77^{\circ} \mathrm{C}\left(170^{\circ} \mathrm{F}\right)$ (Appendix A) during the application. The actual spraying of polyurea and transportation activities is not conducted simultaneously so the application is not a condition "normally incident to transport". However, the affect of the application temperature on the "integrity of the package" with regard to the common gasket materials warrants consideration. Gasket materials are generally synthetic rubbers that have an operating range between $-40^{\circ} \mathrm{C}$ to $125^{\circ} \mathrm{C}\left(-40^{\circ} \mathrm{F}\right.$ to $257^{\circ} \mathrm{F}$ ) and are used in the various Hanford containers, e.g. drums, plywood boxes, fiberglass reinforced plywood (FRP) boxes, concrete and metal boxes. A common gasket material used at Hanford is the nitrile (Buna $\mathrm{N}$ ) rubber that has an operating service temperature range of $-54^{\circ} \mathrm{C}$ to $135^{\circ} \mathrm{C}\left(-65^{\circ} \mathrm{F}\right.$ to $\left.275^{\circ} \mathrm{F}\right)$ (Catalog ORD 5700A/US). Plywood and FRP boxes are nailed or screwed together and their joints and tops may be glued. The top-to-body joints of concrete boxes are caulked. Caulking is typically polymerized siloxanes more commonly known as silicone which is stable at high temperatures, is used as a basic sealant against water and air penetration; however it is not credited with providing containment, confinement, or structural integrity. The polyurea application temperatures are not judged to negatively impact the functionality of these sealants. Therefore, the effectiveness of the common gasket material or Buna $\mathrm{N}$ is not impacted by the actual application of polyurea.

The polyurea applied to the exterior of a structurally sound container that will not be overpacked is the accessible external surface and must not exceed the temperatures stated above. The heat balance for thermal evaluations of packages is the heat generated by the radioactive decay plus the heat from the surroundings minus the heat lost due to convection and radiation. The DOE$\mathrm{RL}$ approved authorizations complete the thermal evaluation of packages with various radioactive decay heat loads, i.e. $12 \mathrm{~W}$ for steel drums, $40 \mathrm{~W}$ for standard waste boxes, and $<50$ W under the Contaminated Equipment Special Package Authorization (SPA) identified in the TSD Appendix I, Section I.3. The solar insolation of $838.3 \mathrm{~W} / \mathrm{m}^{2}\left(265.8 \mathrm{BTU} / \mathrm{h}-\mathrm{ft}^{2}\right)$ represents worst-case values for the Hanford Site during normal conditions for the SWB, HNF-SD-TPSARP-004. The TSD, Table 6-4 reports 12-hour solar insolation as $647 \mathrm{~g}-\mathrm{cal}^{2} / \mathrm{cm}^{2}\left(2,386 \mathrm{Btu} / \mathrm{ft}^{2}\right)$ for flat horizontal surfaces and $324 \mathrm{~g}-\mathrm{cal} / \mathrm{cm}^{2}\left(1,193 \mathrm{Btu} / \mathrm{ft}^{2}\right)$ for curved surfaces. 
HNF-32146, Revision 0

HNF-2209, Part B describes the thermal evaluation for 55 and 85 gallon drums. The thermal evaluation for Standard Waste Boxes (SWB) made from carbon steel is described in HNF-SDTP-SARP-004. The following Table 1 presents the results of these evaluations.

\begin{tabular}{|l|l|l|}
\hline \multicolumn{1}{|c|}{ Table 4.1. Results of the Thermal Evaluations in HNF-2209 and HNF-SD-TD-SARP-004. } \\
\hline Package & $\begin{array}{c}\text { External Temperature in } \\
\text { the Shade }\end{array}$ & \multicolumn{1}{|c|}{$\begin{array}{c}\text { External Temperature Under Worst Case } \\
\text { solar insolation }\end{array}$} \\
\hline 55 Gallon $(12 \mathrm{~W})$ & $47{ }^{\circ} \mathrm{C}\left(116^{\circ} \mathrm{F}\right)$ & $63^{\circ} \mathrm{C}\left(145^{\circ} \mathrm{F}\right)$ \\
\hline 85 Gallon $(12 \mathrm{~W})$ & $46.8^{\circ} \mathrm{C}\left(116.2^{\circ} \mathrm{F}\right)$ & $\begin{array}{l}\text { Average surface } 80.5{ }^{\circ} \mathrm{C}\left(177^{\circ} \mathrm{F}\right) \\
\text { Peak temperature on the lid } 120^{\circ} \mathrm{C}\left(248^{\circ} \mathrm{F}\right)\end{array}$ \\
\hline $\begin{array}{l}\text { Standard Waste Box } \\
(40 \mathrm{~W})\end{array}$ & $63{ }^{\circ} \mathrm{C}\left(145^{\circ} \mathrm{F}\right)$ & $63^{\circ} \mathrm{C}\left(145^{\circ} \mathrm{F}\right)$ \\
\hline
\end{tabular}

The thermal evaluations are evaluated at stead-state thermal conditions so all of the heat generated or absorbed by the drum or box is lost to the environment. The heat balance can be described as:

$$
Q_{\text {decay }}+Q_{\text {solar }}-Q_{\text {convection }}-Q_{\text {radiation }}=0
$$

The heat generation terms are the $Q_{\text {decay }}+Q_{\text {solar }}$. The 12-hour solar insolation is given as 0 for packages located in the shade and the TSD Table 6-4 reports 12-hour solar insolation for horizontal and curved surfaces. Neither of these heat generating terms will be affected by the application of polyurea. The heat rejected from the packages will be via convection and radiation only. Heat transfer by natural convection can be described by the following equation:

$$
Q_{\text {convection }}=h_{c} A_{s}\left(T_{s}-T_{\infty}\right)
$$

Where:

$h_{c}=$ Convection heat transfer coefficient, $\mathrm{W} / \mathrm{m}^{2}-\mathrm{K}$

$A_{s}=$ Surface area, $\mathrm{m}^{2}$,

$T_{s}=$ Surface Temperature, $\mathrm{K}$

$T_{\infty}=$ Ambient temperature, $\mathrm{K}$

Heat transfer by radiation can be described by the following equation:

$$
Q_{\text {radiation }}=\sigma \varepsilon F_{12} A_{r}\left(T_{s}^{4}-T_{\infty}^{4}\right)
$$

Where:

$\sigma=$ Stefan-Boltzmann constant, $5.67 \times 10^{-8} \mathrm{~W} / \mathrm{m}^{2}-\mathrm{K}^{4}$

$\varepsilon=$ Thermal emissivity of the surface, dimensionless, (Irwin 2000)

$F_{12}=$ Gray body view factor, dimensionless, 1 for large surroundings (Irwin 2000)

$A_{r}=$ Effective radiative surface area, $\mathrm{m}^{2}$.

The Stefan-Boltzmann constant is a physical constant of proportionality in the Stefan-Boltzmann law which is defined as the total energy radiated per unit surface area of a black body in unit 


\section{HNF-32146, Revision 0}

time is proportional to the fourth power of the thermodynamic temperature. The emissivity of a material is the ratio of energy radiated by the material to energy radiated by a black body at the same temperature. It is a measure of a material's ability to absorb and radiate energy. A true black body would have an $\varepsilon=1$ while any real object would have $\varepsilon<1$. The application of polyurea to the drums and boxes does not affect the temperatures, convection heat transfer coefficient, Stefan-Boltzmann constant, or the Gray body view factor. Therefore, the three heat transfer terms, assuming all the heat generated and absorbed is lost to the environment, that are affected by an application of polyurea that fully coats the package are as follows:

$A_{s}=$ Surface area, $\mathrm{m}^{2}$,

$A_{\mathrm{r}}=$ effective radiative surface area

$\varepsilon=$ Thermal emissivity of the surface, dimensionless (Irwin 2000).

For packages that are fully coated with a 500 mils $(0.5 \mathrm{inch})$ of polyurea the surface area available for convective heat transfer is larger than the original calculation. The thermal emissivity used in HNF-2209 for the drums is 0.85 for enameled paints on steel at $37.8{ }^{\circ} \mathrm{C}(100$ ${ }^{\circ} \mathrm{F}$ ) and the emissivity used in HNF-SD-TD-SARP-004 for the SWB is 0.9 which is referenced to WHC-SD-WM-SARP-006 which is for zinc based paint. The physical properties of polyurea are very similar to high density polyethylene (HDPE), so the emissivity of HDPE is 0.90 at $37.8^{\circ} \mathrm{C}$ $\left(100^{\circ} \mathrm{F}\right)$ (Irwin 2000) and is judged to be representative of polyurea. Since the heat generated is equal to the heat transmitted to the environment, as the surface area and emissivity of a package are increased the surface temperature is decreased. The larger surface area, created by the application of polyurea, increases the natural convection at steady state conditions and ultimately decreases the surface temperature. The conclusion of this thermal evaluation is that the surface temperature of any package previously determined in DOE approved transportation safety basis documents will bound the surface temperature of packages that are fully coated with polyurea. If follows, that packages with only partially covered surface areas will experience a surface temperature similar to the previously evaluated DOE approved safety basis documents.

The TSD Section B.3.3 Brittle Fracture Acceptable Performance Criteria states "For package containment boundaries and critical components that are constructed from ferritic steels, low temperature brittle fracture of the materials needs to be addressed in a manner similar to certified Type B packages." The polyurea provides some environmental protection. It should help reduce the potential for contamination spread and because it is not ferritic steel, it is not credited with being a critical component, therefore brittle fracture is not evaluated further.

\subsection{CONTAINMENT}

The transportation safety basis that documents the requirements, limits, and controls of riskbased packages used on the Hanford Site address the frequencies and radiological dose consequences of analyzed accidents to establish the risk of using a packaging system. The accident rate used for the Hanford Site in DOE/RL-2001-36 is $2.2 \times 10^{-7}$ accidents per vehicle$\mathrm{km}\left(3.5 \times 10^{-7}\right.$ accidents/vehicle-mi). Reasons for the conservative estimate of frequency include;

- Hanford roadways are relatively flat and straight,

- Hanford Site roadways do not include bridges, tunnels, cliffs, major drops, or similar features, 
- shipments of radioactive materials are limited to $56 \mathrm{~km} / \mathrm{hr}(35 \mathrm{mi} / \mathrm{h})$ or less,

- shipments of radioactive materials are generally made during off-peak traffic hours,

- and shipment of radioactive materials is limited to good weather conditions.

Polyurea coating on a package being transported can not impact any of the above reasons for the accident rate. Therefore, the accident frequency used in the transportation safety basis documents for packaging systems used on the Hanford Site is not changed by the use of polyurea.

The radiological dose consequences of postulated accident scenarios are described in the TSD Appendix G, Section G.1.5 "Dose Consequence Evaluation". The TSD, Appendix G, Section G.2 describes the analysis of three accident types; collision, collision with fire, and hydrogen deflagration. The derivation of dose consequences for these accidents depends largely on the source term of the payload which is not changed by polyurea. Appendix G, Tables $2 a$ and $2 b$ list the specific dose consequences of the above mentioned accidents in the 100/200 Area and the $300 / 400$ Area. Because the polyurea coating is not credited with any structural integrity all the release fractions and damage ratios will remain unchanged. Also, as noted in Section 1.2 of this report, polyurea can not add to, subtract from, or by its use redistribute the radioactive waste material that is placed inside a package. Therefore, the dose consequence analysis that assumes the entire quantity of material at risk (MAR) is exposed to the accident conditions is not challenged by the use of polyurea.

The surface burning characteristics of InstaCote SE FR is described in Appendix B and report describes the results of the ASTM E84 Standard Test Method for SURFACE BURNING CHARACTERISTICS OF BUILDING MATERIALS. The surface flame spread and smoke measurements of the polyurea were compared to mineral fiber cement and select grade red oak. The mineral fiber cement board formed the zero point for both flame spread and smoke developed indexes, while the red oak flooring smoke developed index was set as 100 . The results of the surface burning test indicate the flame spread index is 20 and the smoke developed index is 115 at a thickness of 0.516 in. The Envirolastic AR425, Appendix A, has a flame spread index of 10 and smoke density of 35 at a thickness of 0.020 in, therefore both these products are considered Class A building material by the NFPA. The Solid Waste Operations Complex (SWOC) Fire Hazards Analysis, HNF-21239, Revision 1, Attachment 6, "Analysis Of Polyurea Elastomer Sprayed On Coatings For Various Waste Containers" concludes;

"The fire hazard presented by wood or FRP boxes coated with a polyurea spray on coating is not much different from uncoated wood or FRP boxes. Special treatment is not warranted or required. Wood or FRP boxes that are coated with a polyurea coating can be treated the same as those that are not coated from a fire hazard perspective".

"Metal boxes that are coated with polyurea in accordance with ASTM E84 flame spread test that demonstrates a flame spread of 25 or less can be treated the same as uncoated metal boxes. The metal boxes are robust and a coating of polyurea will not significantly change their performance in a fire." 
The SWOC FHA, HNF-21239, Attachment 6, describes 5 properties and restrictions of sprayed on coatings for drums that are acceptable for storage and handling in SWOC facilities. The sprayed on coatings with low flame spread, lack of dripping and fire spread, good adherence to drums make them acceptable for use on drums in SWOC facilities, however the credit given to these physical properties are not identified in the FHA. Also, the MDSA does not apply Technical Safety Requirement (TSR) level safety class, safety significant, or administrative control status to any of these listed properties.

\subsection{SHIELDING}

The radioactive constituents of packages include a wide variety of radionuclides, but the limiting quantity is dictated by the radiological dose rate to the exterior of a package. The polyurea on the exterior of a package may provide some shielding, however this report does not credit the coating for its shielding qualities. Envirolastic AR 425, Appendix A, can be applied at thicknesses of $30-250$ mils $(0.03-0.25$ inches $)$ or greater. InstaCote SE FR surface burning characteristics, Appendix B, was tested at a thickness of 516 mils (0.516 in) and the MSDS for the cured product does not identify a minimum or maximum thickness.. Alternate thicknesses may be used provided an E84 flame spread test for the specific material and application is performed and the resultant flame spread rating is 25 or less. Due to the variability of the payload, the shielding evaluation estimates the maximum quantity of certain nuclides that may be transported in a single package based on a surface dose rate. Accordingly, the shipper must verify that the dose rate limits are met prior to transport. Because, the application of polyurea does not add to, subtract from, or redistribute the radioactive payload, and the coating of polyurea is not credited with reducing the dose rate, the surface dose rate limits established in the DOE-RL approved safety basis documentation for each package will be applied in accordance with the TSD.

\subsection{CRITICALITY}

Safety basis documentation that establishes the approval for the transportation of packages includes a criticality analysis for NTC, as well as accident conditions. The TSD Appendix D, Administrative Control D.5.3. "Nuclear Criticality Safety" requires that the maximum $\mathrm{K}_{\mathrm{eff}}$ for all packages subject to the TSD is 0.95 , including allowances for bias and uncertainty to provide an adequate margin of safety for transportation activities on site.

The criticality evaluation documented in HNF-2209 indicates that since the isotopic distribution of the fissile material or the $\mathrm{H} / \mathrm{X}$ ratio is not defined, the worst case is assumed $\left({ }^{239} \mathrm{Pu}\right.$ in polyethylene). The conservative assumptions include drum contents of 50 -vol\% polyethylene with an optimum $\mathrm{H} / \mathrm{Pu}$ ratio and full water reflection or infinite arrays. During normal transfer conditions under multiple variations of assumptions the highest $\mathrm{K}_{\text {eff }}$ is calculated to be 0.6091 , HNF-2209, Table B11-8. The accident condition calculations, HNF-2209, Table B11-9 describe $\mathrm{K}_{\mathrm{cff}}$ that approach or exceeds the limits for the infinite arrays. The finite arrays calculations of 19 drums 3 tiers during accident conditions under multiple assumptions of configuration results in $\mathrm{K}_{\text {eff }}$ that does not exceed 0.824 . 


\section{HNF-32146, Revision 0}

The criticality evaluation documented in HNF-SD-TP-004 for the SWB is completed with various densities of polyethylene water mixtures. Four cases in Table B6-4 of HNF-SD-TPSARP-004 compare the $K_{\text {eff }}$ with varying densities for the 60 -vol $\%$ polyethylene $/ 40$-vol $\%$ water mixture outside the sphere, modeled inside the SWB that is reflected, and inside the SWB. The $\mathrm{K}_{\mathrm{eff}}$ of 0.9331 is within the statistical uncertainties as the single package. This demonstrates that the SWBs in the array are neutronically isolated from one another with very little neutron communication between the boxes even with the maximum density polyethylene/water mixture. The analysis of the single-package SWB under accident conditions is identical to the normal conditions i.e. the moderator was assumed to be even more effective than water with the combination of polyethylene and water in the spherical mix with plutonium oxide. The spherical assumption is the most reactive possible. The conservative accident conditions assume the packages are stacked together in an arrangement with close full reflection on all sides of the array by water and with optimum interspersed hydrogenous moderation. These conditions are the same as those for the array calculations under normal conditions. Hence, an additional accident-condition array analysis is not needed. The normal condition calculations were made under the constraint that the SWB shipment can only be one tier high.

The amount of fissile material in the shipment available for release must remain subcritical under the worst conditions. The fissile material quantity or distribution within a package is not changed with an application of polyurea to the outside of a package. The addition of polyurea to the exterior of drums and boxes is bounded by the assumptions of fully reflected and reactive moderator configurations outside the package during normal and accident conditions. The polyurea can not adversely affect the already most reactive conditions of moderation and reflection of neutrons assumed in the analysis. Therefore, the affect of polyurea on criticality safety is judged to be bounded by the existing analysis because the calculations are performed with conservative assumptions.

\subsection{GAS GENERATION}

The accumulation of flammable gas (e.g., hydrogen, low flashpoint hydrocarbons, VOCs) in containers has the potential to occur from radiolytic decomposition of hydrogenous waste, organic waste, or low flashpoint mixed waste or from chemical reaction of incompatible waste forms in conjunction with the failure or absence of vents in the containers. Radiolytic decomposition occurs due to the interaction of the radioactive material (e.g., alpha emitters) with water or organic material in the containers and generates hydrogen. In the absence or failure of vents in the containers, the flammable gases accumulate to the point where a deflagration potential exists (i.e., the lower flammability limit is exceeded). The rate of gas generation depends on several factors, including radionuclide type and radioactivity, organic or hydrogenous material matrix, distribution of radionuclides in the matrix and within the container, and container corrosion. Because much of the waste at Hanford involves organic material contaminated with alpha emitters (TRU waste) inside the container and potentially as surface contamination fixed in place with the polyurea, the bounding scenario assumes hydrogen resulting from radiolytic decomposition of the polyurea caused by gamma radiation is the flammable gas of concern.

The TSD Section 6.5.2.6.15 "Flammable Gas Generation" states 


\section{HNF-32146, Revision 0}

"This section defines the requirements to demonstrate acceptable performance for onsite packaging in which the concentration of flammable gases within the package void volume has the potential to exceed one -half the Lower Explosive Limit (LEL). For Hydrogen gas, the value is $5 \mathrm{vol} \%$. The requirements of this section do not apply to packages that have no flammable gas generation potential."

Transportation packages used on the Hanford Site are used to ship a wide variety of materials that can generate flammable gases from radiolysis, chemical or biological reactions, or the evaporation of organic compounds. HNF-EP-0063, Section 2.11.4 "Gas Generation" states

"When low-level waste is packaged, vents or other measures shall be provided if the potential exists for pressurizing or generating flammable or explosive concentrations of gases within the waste container (DOE M 435.1-1, Chapter IV, L.1.b). Unless otherwise specified by the WSD Project acceptance organization, a minimum five-year time value shall be used to demonstrate compliance when performing gas generation calculations for low-level waste going directly to disposal.

When a container of newly generated transuranic waste is packaged, vents or other mechanisms shall be provided at the time the waste is packaged to prevent pressurization of the container or generation of flammable or explosive concentrations of gases. Containers of currently stored waste shall meet this requirement as soon as practical unless analyses demonstrate that the waste can otherwise be managed safely (DOE M 435.1-1, Chapter III, L.1.b)."

Therefore, recently filled waste packages of either low level or TRU waste will have a vent or other mechanisms to prevent pressurization or the accumulation of flammable or explosive gases. When vents are installed, HNF-EP-0063 Section 2.11.4, requires;

“...a certificate of conformance shall be provided stating the vent model number that has been installed on the waste container and that the waste packaging meets the requirements..."

The installed vent for the control of hydrogen from radiolytic or biological decomposition must be approved and listed in HNF-EP-0063, Appendix H or an approved alternative. The generators of packaged waste are responsible for demonstrating that there is no potential to generate a flammable gas or that the vent mechanism is adequate to ensure that any combination of flammable gases generated since the package was sealed will remain below the flammable atmosphere.

Polyurea applied to the exterior of a retrieved or recently filled waste package does not impact the contents inside the package with regards to the coatings' contribution to the generation of flammable gases. Any container that is vented must not have the vent path blocked after a polyurea coating is applied, so vented status of a container can not be impacted by a coating of polyurea. The SWOC MDSA, HNF-14741, requires that;

"Any container that is considered vented shall have a vent path ensured after it is coated."

The SWOC TSR, HNF-15280, Specific Administrative Control (SAC) 5.6.1, requires; 
"The abatement period ends when the flammable gas hazard is abated (hydrogen concentration is determined to be less than $5 \%$ and other headspace gases are determined to be non-flammable)."

Also the SAC 5.6.1 requires;

"Newly vented containers cannot be moved, other than to a staging area or for resampling, or processed until the flammable gas hazard(s) has been determined to be abated (less than 5\% hydrogen and less than flammable levels for other flammable gases)."

Some waste packages currently being stored or retrieved may not have a vent mechanism installed by the waste generator. The need to sample, process, or vent some of these containers may require the movement of the unvented package. The OTRS, HNF-20961 and HNF-22145 describe administrative and engineered controls to be used to help mitigate the hazards of shipping unvented and vented drums having the potential for greater than $15 \%$ hydrogen.

The autoignition temperature is the minimum temperature required to initiate self-sustained combustion in a combustible fuel mixture in the absence of a source of ignition. In other words, the fuel is heated until it bursts into flame.

Each fuel has a unique auto-ignition temperature. For hydrogen, the auto-ignition temperature is at $585^{\circ} \mathrm{C}\left(1085^{\circ} \mathrm{F}\right)$. HNF-25634, Table 13 provides a list of the minimum auto-ignition temperatures of all the volatile organic compounds of concern. The lowest auto-ignition temperature is for carbon disulfide at $90^{\circ} \mathrm{C}\left(194^{\circ} \mathrm{F}\right)$ with most of the VOCs in the 427 to $482^{\circ} \mathrm{C}$ $\left(800\right.$ to $\left.900^{\circ} \mathrm{F}\right)$ range. This makes it difficult to ignite a hydrogen/VOC/air mixture on the basis of heat alone without some additional ignition source. Since polyurea is applied at $77^{\circ} \mathrm{C}$ $\left(170^{\circ} \mathrm{F}\right)$, the auto-ignition temperature for hydrogen or the VOCs is not reached.

Polyurea, after application and cured, is $100 \%$ solid, i.e. no volatile organic compounds (VOCs) are given off (Appendix A). The elastomeric polyurea chemistry is based on reactive amine terminated resins and high performance isocyanate prepolymers which are known as polyureas. The drying schedule of polyurea to the touch and tack free is about 45 seconds, light traffic is 2 hours, and full cure, to achieve the maximum rated physical properties, is expected in 24 hours, depending on environmental temperatures and moisture, per the MSDS for Envirolastic AR425. The InstaCote SE FR is unaffected by ambient humidity at the time of application and totally impervious to moisture immediately following application.

A review of drum fire/deflagration events throughout the DOE complex has raised concerns that flammable gases other than hydrogen in waste containers could present a hazard. Subsequent analysis and review (HNF-25634, Potential for a Volatile Organic Compound (VOC)

Deflagration in a TRU Drum) determined that quantifiable data was not available to prove concentrations of flammable gases, other than hydrogen, are below their lower flammability limits during and immediately following venting operations. Even though the hydrogen deflagration event is considered to be bounding for the flammable gas deflagration event due to frequency, low ignition energies, and energy generated upon ignition; the potential presence of volatile organic compounds in the waste containers requires controls that have been incorporated into the SWOC TSR and Justification for Continued Operation Involving Transportation Safety Operations Shipment of Drums with Evidence of Prohibited Items, HNF-31228, to confirm that the headspace gases other than hydrogen are nonflammable either by sampling or monitoring. 


\section{HNF-32146, Revision 0}

Analysis of SWOC waste (HNF-9411) indicates that hydrogen accumulation is not expected to be a concern in $95 \%$ of the drums handled. For drums where hydrogen accumulation may be a concern (estimated to be fewer than 900 drums), some retrieval and processing operations are expected to have a higher likelihood of creating the conditions necessary for container deflagration.

It is also possible that flammable gases could accumulate if the vent should fail; the most likely failure mechanism would be plugging. DOE complex experience shows a relatively low rate of vent failure. For example, Rocky Flats found that of the 1,300 drum vents that have been flow tested since $2000,1.8 \%$ had either high or low flow-through and $0.08 \%$ was plugged due to either corrosion or vent surface coating (DNFSB Letter, D.F. Owen to J.K. Fortenberry, "RFETS Activity Report for the Week Ending April 12, 2002"). No plugged vents have been found at the SWOC. However, some waste stored at LLBG may contain chemical constituents (primarily limited quantities of chloride salts and organics) that could cause corrosion of vents since waste acceptance criteria at the time of burial were not as mature as they are today. Available data indicate the presence of such chemicals is possible in up to $5 \%$ of the containers. Therefore, a low percentage of the drums managed at SWOC are expected to show some evidence of vent plugging or failure.

In addition to the drummed waste, there are boxes that may also be used to transport waste materials that could be coated with polyurea to fix surface contamination. However, radioactive surface contamination on the plywood, FRP, or metal box will likely be discovered in proximity of a leak path. This is where the polyurea coating will be applied. It follows that any package fully coated with polyurea will diffuse flammable gases consistent with the physical properties of the polyurea not the original package building materials. The DOE approved transportation safety documents require that flammable gas accumulation inside a package be determined prior to being offered for transportation. HNF-30657, (Draft) One-time Request For Shipment Prohibited Conditions, states;

"Prohibited-condition containers for which there is evidence that they exceed the DOE/RL-2001-36, Appendix G, Table 3, hydrogen concentration limits will be overpacked in vented containers meeting DOT 7A Type A requirements and placed inside an IP-2 container. All overpack and IP-2 containers shall be vented. It is judged to be extremely unlikely that a deflagration accident within the inner container (drum or box) will result in a failure of the entire packaging system and release radioactive material to the environment."

Therefore, fully sealed packages that have an accumulation of flammable gases will be either vented, such that the concentrations are less than Table 3 in the TSD or the specified controls from DOE approved transportation safety documents will be implemented. The mechanism for sealing the exterior of these packages will not impact the transportation activities or operations. 
The area of interest to this technical report is the package that is fully encapsulated with polyurea then placed into an overpack for any reason. The polyurea coating on the exterior of a container that is placed inside of another package becomes part of the payload. According to HNF-EP0063, the generators of packaged waste are responsible for demonstrating that there is no potential to generate a flammable gas or that the vent mechanism is adequate to ensure that any combination of flammable gases generated since the package was sealed will remain below the flammable atmosphere. A 55 gallon drum fully encapsulated with polyurea and placed into an unvented 85-gallon overpack is judged to provide a reasonable assessment of the flammable gas accumulation in the void space of the 85-gallon overpack specifically from the gamma radiolysis of polyurea. An analysis of placing a polyurea coated box into a larger box will include more polyurea, but will also have a larger void space and a larger surface area for diffusion of the flammable gas. Therefore, without quantitative analysis the overpacked 55 gallon package is judged to be reasonable. The Cured polyurea is composed primarily of solid organic compounds, so estimations of the polyurea contribution to hydrogen generation inside an overpack are presented in the next section.

\subsection{HYDROGEN GENERATION CALCULATION}

This section investigates the gas generated in a $500 \mathrm{~g}$ and $200 \mathrm{~g}$ TRU matrix using 20 year aged $12 \%{ }^{240} \mathrm{Pu}$ with ${ }^{241} \mathrm{Am}$ included source term distributed in a matrix of 34 vol\% cellulose, 31 vol\% plastics, and $35 \mathrm{vol} \%$ noncombustible waste in a 55 -gal drum with an exterior coating of polyurea (SARAH). Cellulose is the major constituent of paper and textiles made of cotton, linen and other plant fibers. The polyurea is modeled as High Density Polyethylene (HDPE) Marlex-50 in the hydrogen calculations. The $500 \mathrm{~g}$ is based on the inventory of a single container Material At Risk (MAR) for Waste Management Accidents. Decay of the source will begin in January 1, 1979 with closure of the 55-gal drum on December 31, 1980. The drum is coated with a 500 mil layer of polyurea over its entire surface. The drum exterior, before coating with polyurea is not contaminated. After coating, the drum is placed into an 85 -gal drum with a NucFil-19DS installed and then has a NucFil-007LS inserted through the lid of the 85-gal drum into the 55-gal drum. This calculation will determine the impact of the source term on the waste and polyurea over a 5 year period and the resultant gas generation. The 5 year analysis is conservative, because the TSD, Section 7.3.1.2.7(c)(2) describes a package gas generation potential under $\mathrm{NC}$ for a one-year period beginning when the package is prepared for transport.

The calculations determined that the unvented void of the 85-gal drum containing a 55-gal drum with $500 \mathrm{~g}$ of TRU with $12 \%{ }^{240} \mathrm{Pu}$ contains $1.9 \% \mathrm{H}_{2}$ and without polyurea $0.026 \% \mathrm{H}_{2}$. For comparison purposes the hydrogen gas calculations for an 85 -gal drum containing a 55 -gal container with $200 \mathrm{~g}$ of TRU with $12 \%{ }^{240} \mathrm{Pu}$ contains $0.78 \% \mathrm{H}_{2}$ and without polyurea $0.01 \% \mathrm{H}_{2}$. The Radcalc runs are presented in Appendix C.

\subsubsection{The Source Term Derivation.}

According to the SARAH model, 500 and 200 g of equivalent plutonium at $12 \%{ }^{240} \mathrm{Pu}$ and ${ }^{241} \mathrm{Am}$ based on 20 year aged has a composition according to the following table. 
HNF-32146, Revision 0

\section{Table 8.1 Source Term Derivation}

\begin{tabular}{|c|c|c|c|c|c|c|}
\hline Isotope & Wt\% & $\begin{array}{c}\text { Specific } \\
\text { Activity } \\
(\mathrm{Ci} / \mathrm{g})\end{array}$ & $\begin{array}{c}500 \mathrm{~g} \text { TRU } \\
\text { Source Term } \\
\text { Mass } \\
(\mathrm{g})\end{array}$ & $\begin{array}{c}500 \mathrm{~g} \text { TRU } \\
\text { Source Term } \\
(\mathrm{Ci})\end{array}$ & $\begin{array}{c}200 \mathrm{~g} \text { TRU } \\
\text { Source Term } \\
\text { Mass } \\
(\mathrm{g})\end{array}$ & $\begin{array}{c}200 \mathrm{~g} \text { TRU } \\
\text { Source Term } \\
(\mathrm{Ci})\end{array}$ \\
\hline${ }^{238} \mathrm{Pu}$ & 0.08 & $1.71 \mathrm{E}+01$ & $4.00 \mathrm{E}-01$ & $6.84 \mathrm{E}+00$ & $1.60 \mathrm{E}-01$ & $2.74 \mathrm{E}+00$ \\
\hline${ }^{239} \mathrm{Pu}$ & 83.95 & $6.20 \mathrm{E}-02$ & $4.20 \mathrm{E}+02$ & $2.60 \mathrm{E}+01$ & $1.68 \mathrm{E}+02$ & $1.04 \mathrm{E}+01$ \\
\hline${ }^{240} \mathrm{Pu}$ & 12.97 & $2.27 \mathrm{E}-01$ & $6.49 \mathrm{E}+01$ & $1.47 \mathrm{E}+01$ & $2.59 \mathrm{E}+01$ & $5.89 \mathrm{E}+00$ \\
\hline${ }^{241} \mathrm{Pu}$ & 1.1 & $1.03 \mathrm{E}+02$ & $5.50 \mathrm{E}+00$ & $5.67 \mathrm{E}+02$ & $2.20 \mathrm{E}+00$ & $2.27 \mathrm{E}+02$ \\
\hline${ }^{242} \mathrm{Pu}$ & 0.03 & $3.95 \mathrm{E}-03$ & $1.50 \mathrm{E}-01$ & $5.93 \mathrm{E}-04$ & $6.00 \mathrm{E}-02$ & $2.37 \mathrm{E}-04$ \\
\hline${ }^{241} \mathrm{Am}$ & 1.75 & $3.43 \mathrm{E}+00$ & $8.75 \mathrm{E}+00$ & $3.00 \mathrm{E}+01$ & $3.50 \mathrm{E}+00$ & $1.20 \mathrm{E}+01$ \\
\hline Total & 100 & & $5.00 \mathrm{E}+02$ & $6.44 \mathrm{E}+02$ & $2.00 \mathrm{E}+02$ & $2.58 \mathrm{E}+02$ \\
\hline
\end{tabular}

\subsubsection{Volume (external) of 55-gal drum (from Myers Container ${ }^{\circledR}$ Corporation).}

The volume of polyurea is determined by subtracting the volume of the 55 gallon drum from the volume of the same drum with the polyurea coating. A 500 mil layer of polyurea is equivalent to 0.5 in.

Height, $\mathrm{h}=33.75$ inches

Diameter, $\mathrm{d}=24$ inches

$$
\begin{aligned}
& V_{55-g a l}=\left(\pi \frac{d^{2}}{4}\right) \times h \\
& V_{55-g a l}=\left(\pi \frac{[24]^{2}}{4}\right) \times 33.75 \\
& V_{55-g a l}=15,268 \mathrm{in}^{3} \\
& V_{55-g a l}=0.250 \mathrm{~m}^{3}
\end{aligned}
$$

\footnotetext{
(B) Myers Container is a registered trademark of Myers Container Corporation.
} 
HNF-32146, Revision 0

\subsubsection{Volume (external) of 55-gal drum with polyurea coating (from Myers Container Corporation).}

The polyurea coating is assumed to 0.5 inch thick, fully covering the entire drum.

$$
\begin{aligned}
& \mathrm{h}=34.75 \text { inches } \\
& \mathrm{d}=25 \text { inches } \\
& V_{55-\text { gal-coat }}=\left(\pi \frac{d^{2}}{4}\right) \times h \\
& V_{55-\text { gal-cout }}=\left(\pi \frac{[25]^{2}}{4}\right) \times 34.75 \\
& V_{55-\text { gal-coat }}=17,057.9 \mathrm{in}^{3} \\
& V_{55-\text { gal-coat }}=0.280 \mathrm{~m}^{3}
\end{aligned}
$$

\subsubsection{Density of Polyurea:}

Polyurea can be applied at multiple formulations so the density used for these calculations is approximated according to the data presented on the test sample of material in InstaCote SE FR tests (Appendix B) and the density of the Envirolast AR425 is $1102 \mathrm{~kg} / \mathrm{m}^{3}$ (Appendix A) so using the InstaCote is conservative.

Width of sample $=24$ inches

Length of sample $=24$ feet $=288$ inches

Thickness of sample $=0.516$ inches

Mass of sample $=155.5 \mathrm{lbs}$

$$
\begin{aligned}
& \text { density }_{\text {polyurea }}=M_{\text {polyurea }} \div V_{\text {polyurea }} \\
& V_{\text {polyurea }}=l \times w \times h \\
& V_{\text {polyurea }}=288 \text { inches } \times 24 \text { inches } \times 0.516 \text { inches } \\
& V_{\text {pelyurea }}=3566.6 \mathrm{in}^{3} \\
& \text { density }_{\text {polyurea }}=155.5 \mathrm{lbs} \div 3566.6 \mathrm{in}^{3} \\
& \text { density }_{\text {polyurea }}=0.044 \mathrm{lbs} / \mathrm{in}^{3} \\
& \text { density }_{\text {polyurea }}=1218 \mathrm{~kg} / \mathrm{m}^{3}
\end{aligned}
$$


HNF-32146, Revision 0

\subsubsection{Volume and mass of polyurea after it is applied to the drum:}

$$
\begin{aligned}
& V_{\text {pollyurea }}=V_{55-\text { gal-coat }}-V_{55-\text { gal }} \\
& V_{\text {pollyurea }}=0.280 \mathrm{~m}^{3}-0.250 \mathrm{~m}^{3} \\
& V_{\text {pollyurea }}=0.030 \mathrm{~m}^{3} \\
& M_{\text {pollyurea }}=V_{\text {polyurea }} \times \text { density }_{\text {polyurea }} \\
& M_{\text {polyurea }}=0.030 \mathrm{~m}^{3} \times 1218 \mathrm{~kg} / \mathrm{m}^{3} \\
& M_{\text {polyurea }}=36.54 \mathrm{~kg}
\end{aligned}
$$

\subsubsection{Volume of 85-gal drum (Myers Container Corporation).}

The scenario for these calculations assumes the polyurea coated 55 gallon drum is placed in an 85 gallon overpack. The reason or need to overpack the 55 gallon drum is a facility operations decision and does not impact these calculations.

$$
V_{85}=0.322 \mathrm{~m}^{3}
$$

\subsubsection{Void of 85-gal drum.}

The 55-gallon drum is centered in the 85-gallon drum with wooden wedges located at the top of the drum. These wedges are assumed to be made of Douglas Fir and weigh $1 \mathrm{~kg}$.

$$
\begin{aligned}
& M_{\text {wedgex }}=1 \mathrm{~kg} \\
& \text { density }_{\text {douglasfir }}=560.6 \mathrm{~kg} / \mathrm{m}^{3} \text { (Douglas fir : Pocket Reference, } 3 \text { rd Edition) } \\
& V_{\text {wedges }}=M_{\text {wedges }} \div \text { density donglasifir } \\
& V_{\text {wedges }}=1 \mathrm{~kg} \div 560.6 \mathrm{~kg} / \mathrm{m}^{3} \\
& V_{\text {wedges }}=.0018 \mathrm{~m}^{3} \\
& V_{\text {void-85 }}=V_{85}-V_{55-\text { yal-cout }}-V_{\text {wedges }} \\
& V_{\text {void }-85}=0.322 m^{3}-0.280 m^{3}-0.0018 m^{3} \\
& V_{\text {void }-85}=0.0402 \mathrm{~m}^{3}
\end{aligned}
$$

\subsubsection{Weight Percent of 85-gal Drum.}

The recommended payload weight limit for an 85 gallon drum is:

$$
(435 \mathrm{~kg}-35.4 \mathrm{~kg})=399.6 \mathrm{~kg}(881 \mathrm{lb}),
$$

where,

85 gallon gross weight is $435 \mathrm{~kg}$ (959.0 lb),

85 gallon tare weight is $35.4 \mathrm{~kg}(78.0 \mathrm{lb})$. 
The wood wedges are $1 \mathrm{~kg}$ and the polyurea is estimated to weigh $36.54 \mathrm{~kg}(80.6 \mathrm{lb})$. Therefore, the contents of the 55 gallon drum can not weigh more than:

$$
\begin{gathered}
399.6 \mathrm{~kg}-1 \mathrm{~kg}-36.54 \mathrm{~kg}=362.06 \mathrm{~kg}, \text { or } \\
881 \mathrm{lb}-2.2 \mathrm{lb}-80.6 \mathrm{lb}=798.2 \mathrm{lb}
\end{gathered}
$$

The weight fractions are described in Table 8.2.

\begin{tabular}{|l|c|c|c|}
\hline \multicolumn{4}{|c|}{ Table 8.2. Weight Fraction of the 85 gal Overpack for Input to Radcalc } \\
\hline & $\begin{array}{c}\text { Weight } \\
(\mathrm{kg})\end{array}$ & $\begin{array}{c}\text { Weight } \\
(\%)\end{array}$ & $\begin{array}{c}\text { Weight \% } \\
\text { Composition }\end{array}$ \\
\hline$M_{55 \text {-gal }}$ & 362.06 & 90.6 & USER \\
\hline$M_{\text {wood }}$ & 1.0 & 0.25 & $\begin{array}{c}\text { Wooden Shims } \\
\text { (cellulose) }\end{array}$ \\
\hline$M_{\text {polyurea }}$ & 36.54 & 9.14 & $\begin{array}{c}\text { Polyethylene (HDPE } \\
\text { Marlex-50) }\end{array}$ \\
\hline$M_{\text {waste }}$ & 399.6 & & \\
\hline
\end{tabular}

\subsubsection{Waste Percent, Waste Volume, and Void Volume without Polyurea}

$$
\begin{aligned}
& V_{55-\text { gal }}=0.250 \mathrm{~m}^{3} \\
& V_{\text {wood }}=0.0018 \mathrm{~m}^{3} \\
& V_{85}=0.322 \mathrm{~m}^{3} \\
& V_{\text {waste }}=V_{55-\text { gal }}+V_{\text {wood }} \\
& V_{\text {waste }}=0.250 \mathrm{~m}^{3}+0.0018 \mathrm{~m}^{3} \\
& V_{\text {waste }}=0.252 \mathrm{~m}^{3} \\
& V_{\text {void }}=V_{85}-V_{\text {woodd }}-V_{55-\text { gal }} \\
& V_{\text {void }}=0.322 \mathrm{~m}^{3}-0.0018 \mathrm{~m}^{3}-0.250 \mathrm{~m}^{3} \\
& V_{\text {void }}=0.0702 \mathrm{~m}^{3}
\end{aligned}
$$


HNF-32146, Revision 0

\begin{tabular}{|l|c|c|c|}
\hline $\begin{array}{l}\text { Table 8.3. Weight Fraction of the 85 gal Overpack w/o Polyurea for Input } \\
\text { to Radcalc }\end{array}$ & $\begin{array}{c}\text { Weight } \\
(\mathrm{kg})\end{array}$ & $\begin{array}{c}\text { Weight } \\
(\%)\end{array}$ & $\begin{array}{c}\text { Weight \% } \\
\text { Composition }\end{array}$ \\
\hline$M_{55 \text {-gal }}$ & 362.06 & 99.7 & USER \\
\hline$M_{\text {wood }}$ & 1.0 & 0.3 & $\begin{array}{c}\text { Wooden Shims } \\
\text { (cellulose) }\end{array}$ \\
\hline$M_{\text {polyurea }}$ & 0 & 0 & $\begin{array}{c}\text { Polyethylene (HDPE } \\
\text { Marlex-50) }\end{array}$ \\
\hline$M_{\text {waste }}$ & 363.06 & & \\
\hline
\end{tabular}

The Radcalc runs are located in Appendix C and Table 8.4 summarizes results.

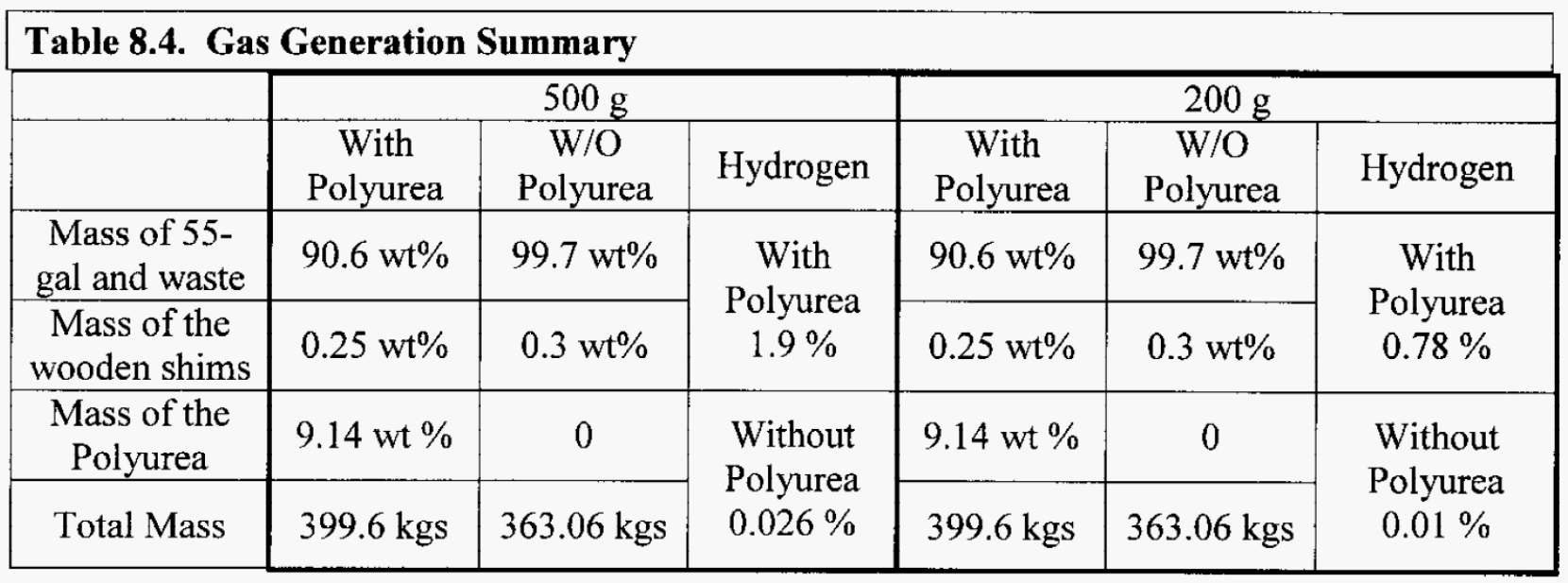

\subsection{TIE DOWN AND PACKAGE RIGGING}

The tiedown systems required by safety basis documentation for packages and the TSD shall be implemented as described in the safety basis documents for each packaging system. Packages transported on an open or in a covered conveyance must comply with the tiedown system required for that package. No integral lifting or tiedown devices are provided on drums. Generally lifting and/or tiedown devices are not on other containers unless specifically designed and evaluated in the safety basis documentation for the special case. The general rules for protection against shifting or falling cargo applies to all packages and the application of polyurea coatings is not credited with adding to or subtracting from those protection rules. 
The primary requirement for the application of polyurea is that containers must be structurally sound according to the criteria for that package. The additional dimensions created by the polyurea thickness may result in mechanical considerations for a tiedown system but because the polyurea can not exceed the weight limits for any package, the use of and robustness of the system can not be impacted. Also, common methods used to achieve package damage control such as speed limits, the use of sandbags or dunnage containers, and tiedowns must not be affected by the application of polyurea.

Tiedown system designs are required to meet the applicable requirements of 49 CFR 393, Subpart I for the various types of packages and conveyances used on the Hanford site. Generally, the designs must address the static forces applied at the center gravity of the packages, the vertical and horizontal component both in the direction of the conveyance and the transverse direction all based on the gross weight of the package. Requirements from the tie down analysis include a rubber load mat with a minimum frictional coefficient of 0.8 be placed on a clean, dry, debris-free, and oil-free surface. However, the coefficient of friction between secured packages and the rubber mat is not a parameter of analysis. The designated chain binders, or straps with ratchets placed over the top of packages for upward restraint are derived from significantly conservative tie down analysis. For example, HNF-SD-TP-SARP-004 describes the inertial loading specified for the SWB enhanced tie down that is approximately 10 times greater than the DOT requirements. It is judged that the tie down analysis incorporates conservative parameters that compensate any reduction of friction caused by the surface texture of a polyurea coated bottom of a package versus the original package surface.

\subsection{QUALITY ASSURANCE}

Fluor Hanford (FH) implements a Quality Assurance (QA) Program as described in HNF-11724, Chapter 14.0, Fluor Hanford Safety Management Programs. The QA program described in HNF-1 1724 including applications of graded approach is applicable within the scope of the PHMC (DE-AC06-96RL13200) as required by the TSD Section 6.2. For design, fabrication, procurement, use, or maintenance of onsite fissile and Type B packagings, the requirements are as delineated in 10 CFR 71 Subpart H or Nuclear Quality Assurance (NQA-1) or demonstrated equivalent. A key element of HNF-11724, Chapter 14.0 is described as "FH implements a QA program meeting the requirements of 10 CFR 830, "Nuclear Safety Management," Subpart A, "Quality Assurance Requirements," in accordance with HNF-MP-599, Quality Assurance Program Description." The Quality Assurance Program Plan (QAPP), HNF-25689, defines the QA requirements that shall be implemented for the Transportation and Packaging activities. The QAPP applies to all FH T\&P activities across the Hanford Site, which supports multiple contractors, projects, and/or facilities. The application of polyurea does not affect or adversely impact the implementation of the QA program as described in the TSD, HNF-11724 or HNF-25689.

\subsection{ACCEPTANCE TESTS AND MAINTENANCE PROGRAM REVIEW}

The maintenance of packages for transportation shall be per the manufacture's recommendations, instructions, and or the packaging safety basis authorization. Whenever possible, empty and new packages shall be stored indoors or under protective cover to eliminate or minimize the effects of 
the sun, wind, rain, or other environmental conditions that could cause environmental degradation. Inspections of new and retrieved packages are required prior to transport. Because the intent of a polyurea coating is to enhance the weatherization or contamination control qualities of a package it will likely be used primarily for retrieved packages, however this OTRS does not restrict the transportation of new packages that have a polyurea coating.

The visual container inspections shall confirm that there is no container material degradation that could affect the structural integrity of the packaging. Inspections include external contaminations, external dose rates, package markings, package bottom, and closure features. The visual inspection of a package's external surface will not be possible when polyurea has been applied. However, the primary control delineated in this OTRS is that containers must be structurally sound prior to the polyurea application. Therefore, facility operations must confirm, document, and provide for review evidence that the structural integrity of packages is sound prior to the application of polyurea.

\subsection{OPERATING PROCEDURES}

This report does not identify controls or limitations placed on the transportation of packages specifically because of the application of polyurea, other than the requirement to ensure the polyurea is fully cured prior to acceptance for transportation activities. The packages may be stand alone structurally sound with a polyurea coating on the exterior or the package may be an overpack with a payload that includes polyurea. The facility operating procedures that implement TSD TSR controls derived from the transportation safety basis documentation for each package are not modified, revised, or in anyway changed by this report.

The TSD Appendix D Technical Safety Requirements (TSRs) are administrative limitations and controls that ensure the safe packaging and transportation of hazardous materials on the Hanford Site. These administrative controls address the provisions relating to organization and management, procedures, recordkeeping, audits, and specific program requirements for risk reduction necessary to ensure safe operation of the packaging system. The TSR requires a formal program that includes organization structure, nuclear criticality safety, gas accumulation minimization, package damage ratio minimization for risk-based packages, surveillance and maintenance, and configuration management. The key elements of required programs are implemented through facility operating procedures. This report does not change operating procedures that implement the transportation safety basis documents, other than the requirement to ensure the polyurea is fully cured prior to acceptance for transportation activities. .

Polyurea is not credited with any required mitigating feature that should be implemented with in facility operating procedures or controls. The packages with an external application of polyurea shall be structurally sound according to the criteria described in the facilities Container Management Program which generally includes the waste acceptance criteria. The utilization of polyurea as part of contamination control has no impact on the requirements for transportation of polyurea coated packages because the polyurea is not credited with any mitigating feature. 
HNF-32146, Revision 0

\subsection{REFERENCES}

DE-AC06-96RL13200, 1996, Contract Between the U.S. Department of Energy, Richland Operations Office, and Fluor Daniel Hanford, Inc., U.S. Department of Energy, Richland Operations Office, Richland, Washington, as amended.

DNFSB Letter, D.F. Owen to J.K. Fortenberry, "RFETS Activity Report for the Week Ending April 12, $2002 "$

10 CFR 830, Code of Federal Regulations, "Nuclear Safety Management," as amended.

10 CFR 71, Subpart H, Code of Federal Regulations, "Energy", "Packaging and Transportation of Radioactive Material", as amended.

49 CFR 393, Subpart I, Code of Federal Regulations, "Transportation", "Parts and Accessories Necessary for Safe Operation", "Protection Against Shifting and Falling Cargo",as amended

DOE/RL-2001-36, Hanford Sitewide Transportation Safety Document, U.S. Department of Energy, Richland Operations Office, Richland Washington.

DOE M 435.1-1, Radioactive Waste Management Manual, U. S. Department of Energy, Washington, D. C.

HNF-2209, Safety Analysis Report for Packaging (Onsite) Steel Drum, as amended, Fluor Hanford, Inc., Richland Washington.

HNF-8739, Hanford Safety Analysis and Risk Assessment Handbook (SARAH), as amended, Fluor Hanford Inc., Richland, Washington.

HNF-9411, Analysis of Available Hydrogen Data and Accumulation of Hydrogen in Unvented TRU Drums, Fluor Hanford Inc., Richland, Washington.

HNF-20961, Evaluation of Drums Suspected to Contain Greater Than 5\% Hydrogen, Fluor Hanford, Inc., Richland Washington.

HNF-22145, Request for the Approval to Transport Degraded or Suspect Packagings Onsite Within an Overpack Container Meeting United States (US) Department of Transportation (DOT) Industrial Package (IP) Type I Performance Requirements, Fluor Hanford Inc., Richland Washington.

HNF-14741, Master Documented Safety Analysis (MDSA) for the Solid Waste Operations Complex ( $S W O C$ ), as amended, Fluor Hanford, Inc., Richland, Washington.

HNF-15280, Technical Safety Requirements for the Solid Waste Operations Complex, as amended, Fluor Hanford, Inc., Richland, Washington.

HNF-23196, Process Description for Polyurea Coating of Retrieved Drums, Fluor Hanford Inc., Richland Washington.

HNF-21239, SWOC Fire Hazards Analysis, as amended, Fluor Hanford, Richland Washington.

HNF-22145, One-time Request for Shipment of Retrieval Packages in IP-1 Overpack, Fluor Hanford Inc., Richland Washington.

HNF-24886, Preliminary Hazards Analysis for Polyurea Application in the Low-Level Burial Grounds, Fluor Hanford Inc., Richland Washington.

HNF-25634, Potential for a Volatile Organic Compound (VOC) Deflagration in a TRU Drum, Fluor Hanford Inc., Richland, Washington.. 
HNF-32146, Revision 0

HNF-25689, Transportation and packaging Program Quality Assurance Program Plan, Fluor Hanford Inc., Richland Washington.WHC-SD-TP-SARP-018, Safety Analysis Report for Packaging (Onsite) for Type B Quantities of Radioactive Material in Type A Boxes, as amended, Fluor Hanford Inc., Richland Washington.

HNF-31228, Justification for Continued Operation Involving Transportation Safety Operations Shipment of Drums with Evidence of Prohibited Items, Fluor Hanford Inc., Richland, Wa.

HNF-31617, Package Specific Safety Document for Steel Drums, DRAFT.

HNF-1 1724, Fluor Hanford Safety Management Programs, as amended, Fluor Hanford Inc., Richland, Washington.

HNF-EP-0063, Hanford Site Solid Waste Acceptance Criteria, as amended, Fluor Hanford Inc., Richland, Washington.

HNF-MP-599, Quality Assurance Program Description, as amended, Fluor Hanford, Richland, Washington.

HNF-SD-TP-SARP-004, Safety Analysis Report for Packaging (Onsite) Standard Waste Box, Fluor Hanford Inc., Richland, Washington.

Catalog ORD 5700A/US, 2001, Parker O-Ring Handbook, Parker Hannifin Corporation, Cleveland, Ohio.

RPP-12710, Flammable Gas Diffusion From Waste Transfer Associated Structures.

WHC-SD-TP-RPT-004, Environmental Conditions for On-Site Hazardous Materials Packages, Westinghouse Hanford Company, Richland, Washington.

WHC-SD-WM-SARP-006, Safety Analysis Report for Packaging (Onsite) 85 Gallon Retrieval Drum, Westinghouse Hanford Company, Richland, Washington.

WAC 173-303, "Dangerous Waste Regulations," Washington Administrative Code, as amended. 
HNF-32146, Revision 0

Appendix A

APPENDIX A

ENVIROLASTIC AR425 DATA SHEET AND INSTACOTE INFORMATION DATA

Page A-1 
HNF-32146, Revision 0

Appendix A

Figure 1. Envirolastic AR425 - Manufacturer's Data Sheet

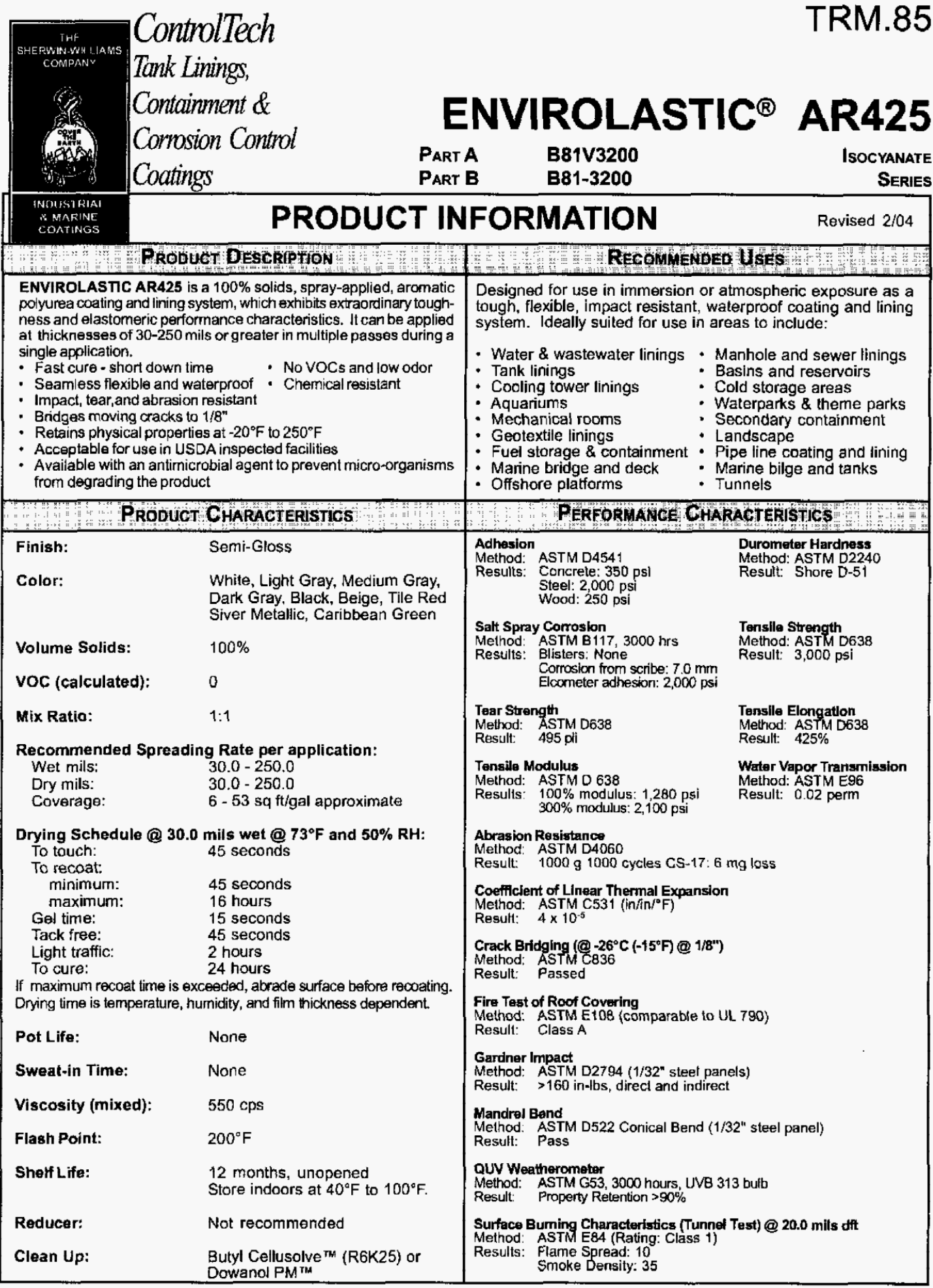




\section{Appendix A}

Figure 1. Envirolastic AR425 - Manufacturer's Data Sheet (cont'd)

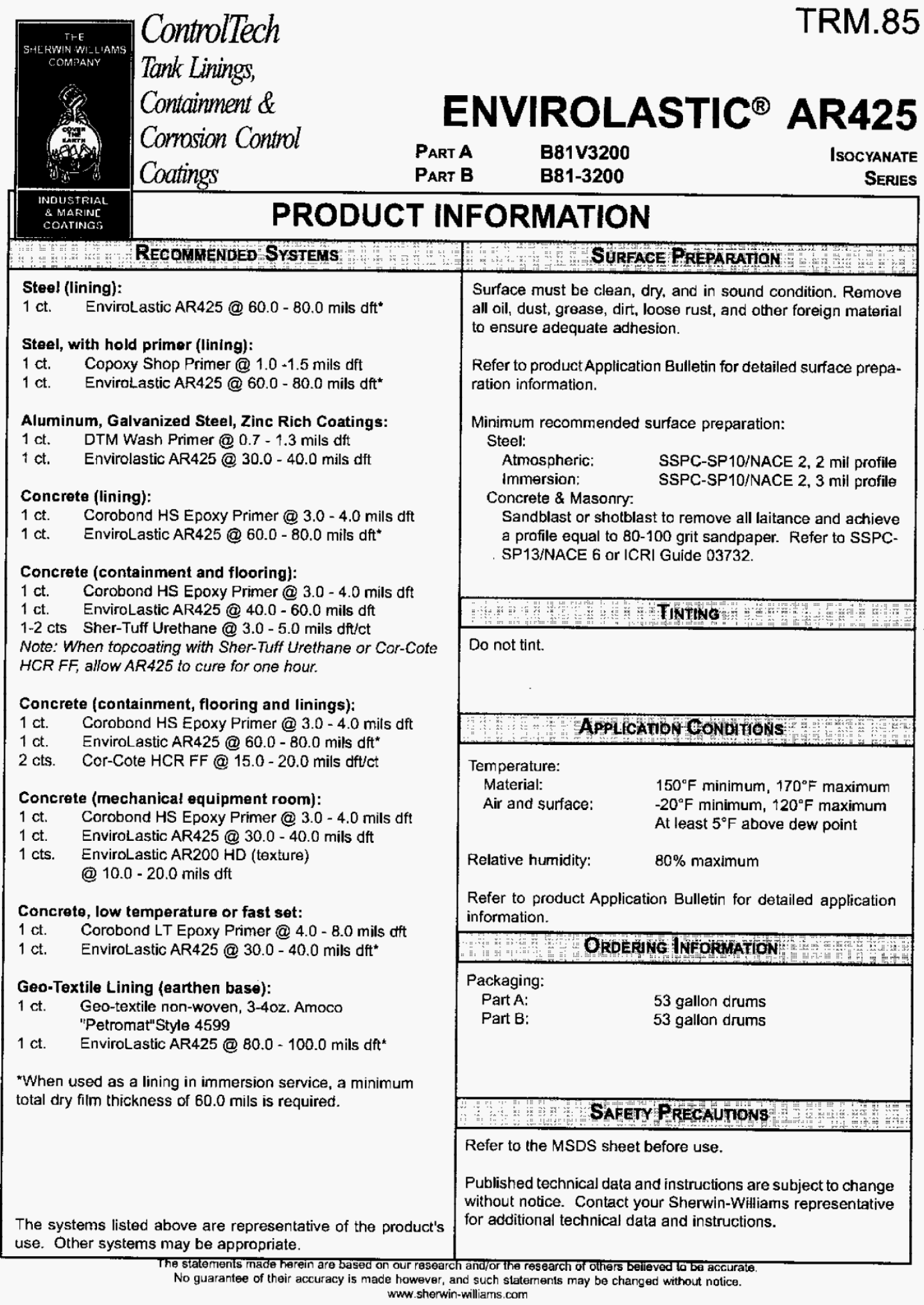

Tank Linings,

Containment \& Corrasion Control PRODUCT INFORMATION 
HNF-32146, Revision 0

\author{
Appendix A
}

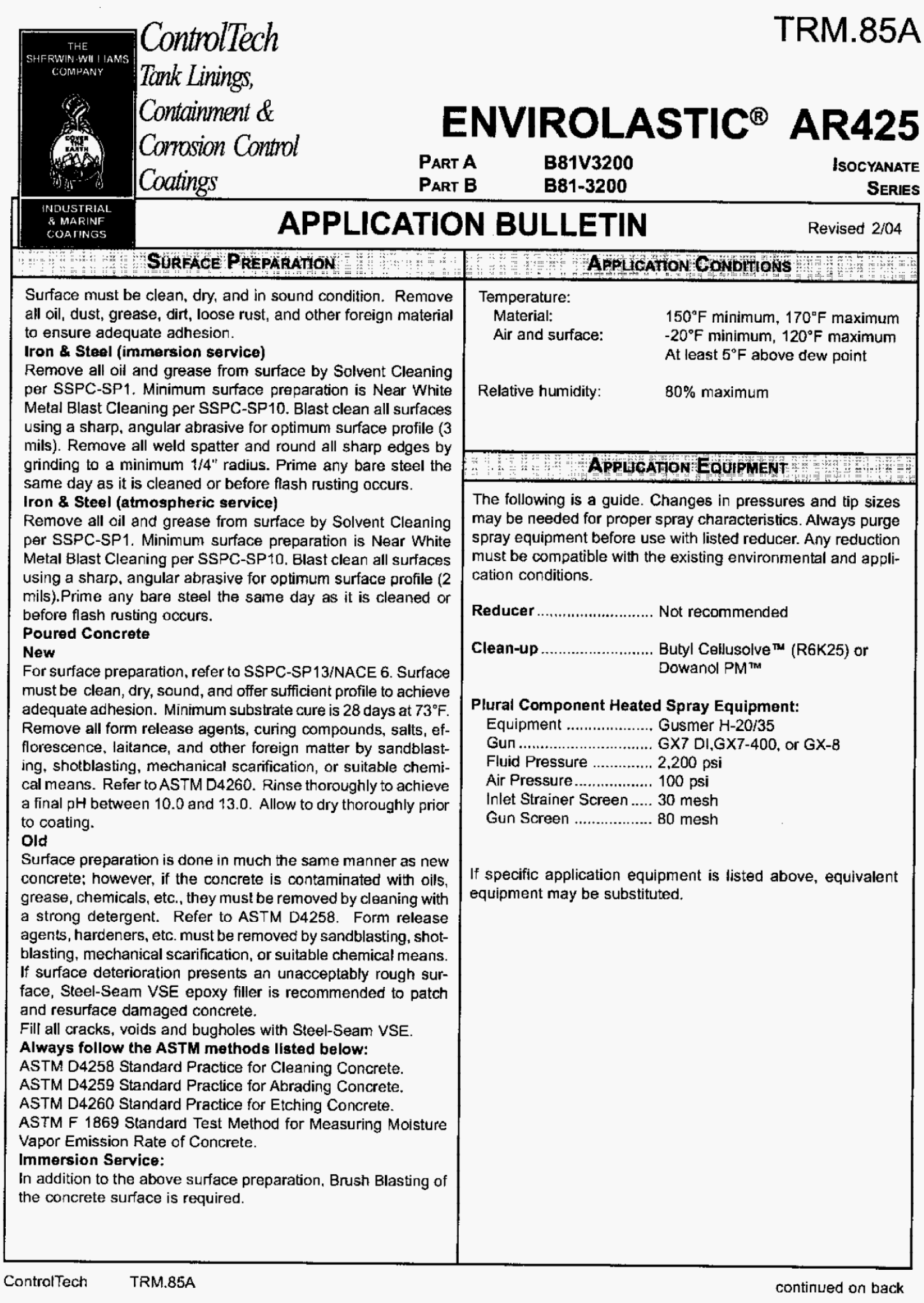

\title{
Figure 1. Envirolastic AR425 - Manufacturer's Data Sheet (cont'd)
}




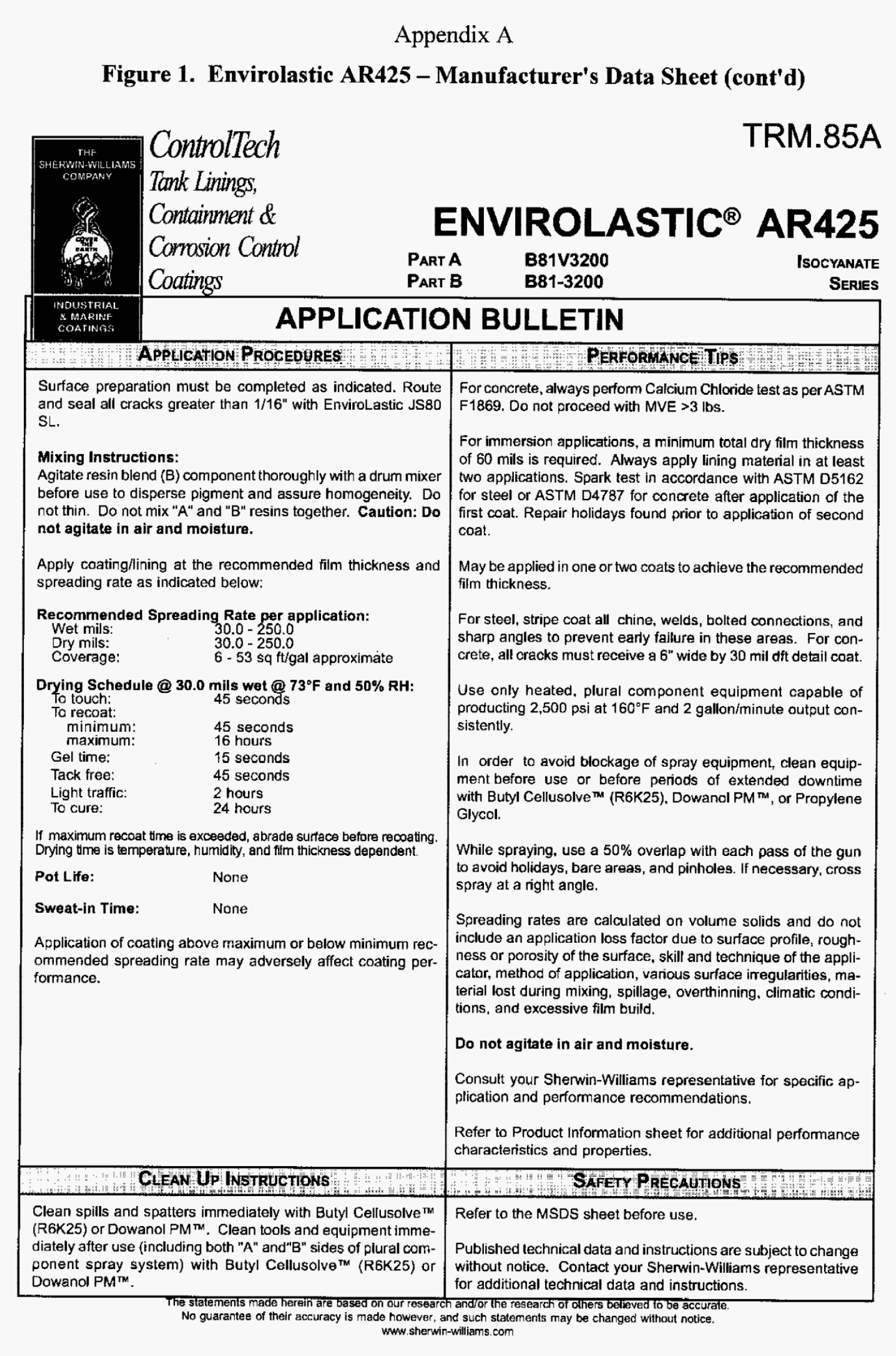

.

\author{
HNF-32146, Revision 0
}

.

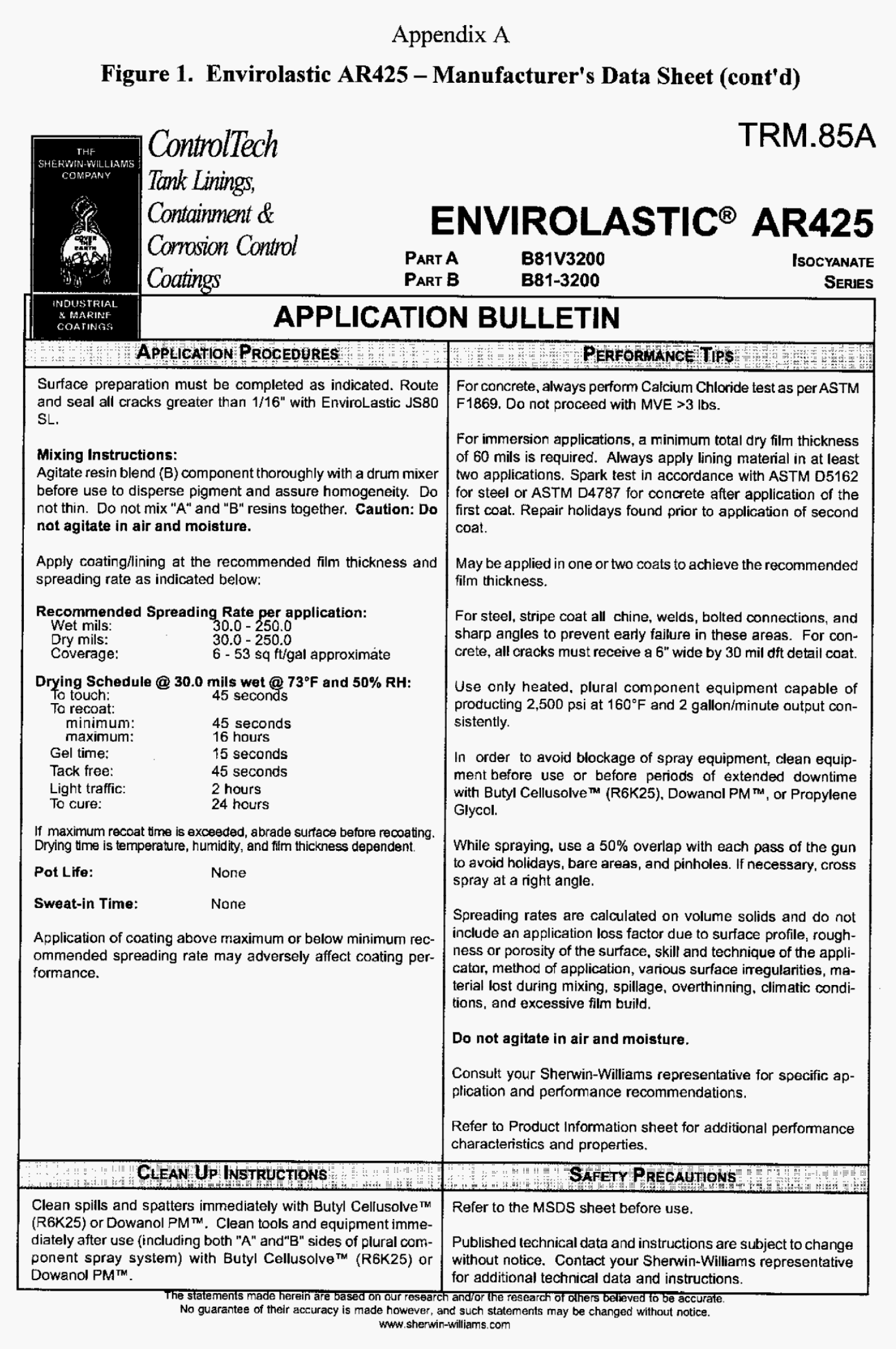

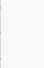

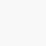
.

\author{
A-
}


HNF-32146, Revision 0

Appendix A

\section{INSTACOTE}

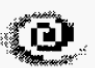

ENVIRONMENTAL COATINGS

To: Gary Dukelow

$3 / 23 / 07$

From: Tom Nachtman

Here is the consolidated list of questions that will be needed to answer DOE's concerns; all of them apply to the cured polyurea:

1. What happens when polyurea is cut with a rotary or reciprocating saw as far as hazardous vapors given off or any other effect? For example, when a coated wooden box has to have its top cut off.

We have a lot of experience using hole saws and saws-alls to cut cured polyurea. There are no hazardous vapors. The heat generated by the process of cutting does not gum up the blades.

2. What if a coated metal box is cut with an acetylene torch; are there any hazardous vapors or any other effect?

We strongly do not recommend using an acetylene torch, however if you use an acetylene torch it will burn in the area of the flame and will go out when flame is removed. Generally gases produced are carbon dioxide, carbon monoxide and nitrogen oxide. InstaCote does have customers that weld steel racks which are sprayed with polyurea. This is accomplished with removing the InstaCote and spot welding a bare area.

3. Information on the effects of radiation; Envirolastic was tested to $10^{7} \mathrm{Rad}$ with essentially no effects except for color modification.

InstaCote polyurea was tested to $10.010^{6} \mathrm{R}$ ? Gamma Dose with little effect to the properties. A discoloration is all one should expect to see. The University of Michigan Irradiation study is available upon request.

4. Effects of UV 


\section{HNF-32146, Revision 0}

\section{Appendix A}

UV degradation is not to be expected with Polyurea. InstaCote has had material outside for 15 years with minimal effect on the elastomer. Some slight graying and loss of gloss is to be expected. The elastomer will not lose its integrity due to UV exposure. Rocky Flats sprayed many large objects and staged them for up to a year outside with no visible effects seen to the Instacote SE FR.

5. Effects of thermal cycling from ambient weather conditions

Polyurea was originally developed for use in the automotive industry and is still used today because of the ability of the material to withstand thermal cycling and seasonal variations.

6. Basis or similarity with Envirolastic 425 MSDS part B statement (previously faxed) that "dust at sufficient concentrations can form explosive mixtures with air.

Instacote polyurea does not create explosive mixtures of dust during dispensing. Explosive mixtures would require combustible gases, vapors, mist, or combustible dust and fibers.

InstaCote polyurea system is never sprayed using a single component ie. Part B.

7. As many of the equivalent "Performance Characteristics" as you have compared to the attached Envirolastic 425 dato sheet

\section{S-W properties}

Tensile

Elongation

Hardness

Tack free

Gel time

Cure
$3000 \#$

$425 \%$

$51-D$

45 seconds

15 seconds
InstaCote SE FR- HCET (detailed report)

2500 to $2700 \#$

$350 \%$

54-D

25 - 30 seconds

$3-4$ seconds

\section{Temperature range that physical characteristics are retained}

InstaCote polyurea physical properties have serviceability from $-40^{\circ} \mathrm{F}$ to $350^{\circ} \mathrm{F}$. The Hemispheric Center for Environmental Technology final report is available upon request.

9. Moving crack bridging capability.

Bridging of cracks and filling voids areas is accomplished through craft technique during dispensing. This will be a part of the training.

10. Life expectancy of cured product

Based on the available information we have to date, it is felt that a properly formulated and prepared polyurea elastomer system, like that of the InstaCote product line, would survive a minimum of 100 years in your buried and above ground application areas, especially at the $\frac{1}{4}$ inch 
HNF-32146, Revision 0

Appendix A

applied thickness. This is based on the testing, flexibility of the system, chemical resistance and thermal properties.

11. Are there any conditions that might promote embrittlement or cracking?

No, the cured polyurea elastomer "InstaCote" is very stable and resistant to environmental conditions.

160 C. LAVOY RD. ERIE, MI 48133 - PHONE (734) 847-5260 - FAX (734) 847-9008 
HNF-32146, Revision 0

Appendix B

APPENDIX B

FLAME SPREAD TESTING DATA

Page B-1 
HNF-32146, Revision 0

Appendix B

\section{ASTM E84-00a \\ SURFACE BURNING CHARACTERISTICS}

InstaCote SE FR (Resin Test No: 2)

Report No. $15806-112542$

Novernber 7, 2002

Prepared For:

InstaCote, Inc.

$160 \mathrm{C}$ Lavoy Road

Erie, MI 48133, U.S.A.
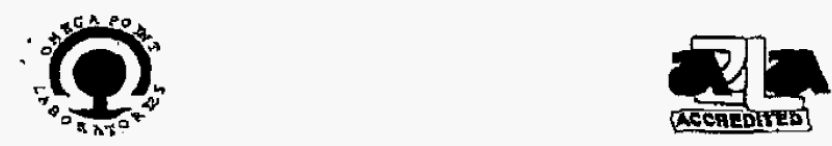

Page B-2 
HNF-32146, Revision 0

Appendix B

Report No. 1580 - 112542

InstáCote, Inc.

Pago ii of ii

November 7, 2002

\section{ABSTRACT}

Test Material: InstaCote SE FR (Resin Test No: 2)

Test Standard: ASTM E84-00a Standard Test Method for SURFACE BURNING CHARACTERISTICS OF BUILDING MATERIALS'(ANST 2.5, NFPA 255, UBC 8-1, UL 723)

Test Date:

November 7, 2002

Test Sponsor:

InstaCote, Inc.

Test Results:

FLAMIE SPREAD INDIEX SMOKE DEVELOPED INDEX

$$
=\quad 20
$$

The description of the test procedure and specimen evaluated, as well as the observations and results obtained, contained herein are true and acculate within the limits of sound ongimenring practice. These results are valid only for the specimen(s) tested and may not

represent the performanote of other specimens from the same or other production lots

Omega Point Iaboratories, Iac. authorizes the client named herein wo reproduce this repart only if repraduced in its extrirety.

The test specimen identification is as provided by the client and Omega Point Laboratories accepts no responsibility for any inaccuracies therein.

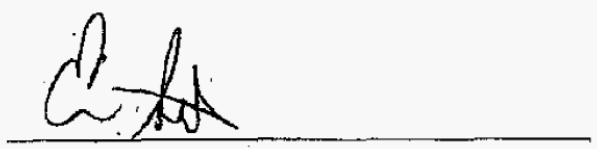

Errie Schroidt

Director, Flammability Testing

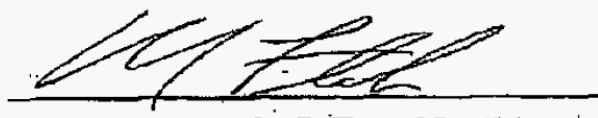

William E. Fitch, P.E. No. 55296

Executive Vice President
Date: November 7,2002

Date: November 7,2002 


\section{Appendix B}

\section{INTRODUCTION}

This report describes the results of the ASTM E84 Standard Test Method for SURFACE BURNING CHARACTERISTICS OF BUILDING MATERIALS (1), a method for determining the comparative surface burning behavior of building materials. This test is applicable to exposed surfaces, such as ceilings or walls, provided that the material or assembly of materials, by its own structural quality or the manner in which it is tested and intended for use, is capable of supporting itself in position or being supported during the test period.

The purpose of the method is ta determine the relative burning behavior of the material by observing the flame spread along the specimen. Flame spread and smolse density developed are reported, however, there is not necessarily a relationship between these two measuremonts.

"The use of supporting materials on the underside of the test specimen may lower the flame spread index from that which might be obtained if the specimen could be tested without such support... This method may nnt be appropriate for abtaining comparative surface burning behavior of some cellunlar plastic materials... Testing of materials that melt, drip, or delaminate to such a degree that the continuity of the flame front is destroyed, results iz low flame spread indices that da not relate directly to indices obtained by testing materials that remain in place."

This test Inethod is also published under the following designations:

\section{ANSI 2.5}

NFPA 255

UBC 8-1 (42-1)

UL 723

This standard should be used to measure and describe the properties of materials, products, or assemblies in response to heat and flame under controlled laboratory conditions and should that be used to describe or appraise the fire hazard or fine rish of materials, produets, or assemblies under actual fire canditions. However, results of this test may be used as elements of a fire rish assessmient which takes into account all of the factors which are pertinent to an assessment of the fine hazard of a particular end use.

(1) American Society for Testing and Materials (ASTM), Committee E-5 on Fire Standards

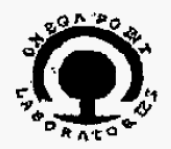


HNF-32146, Revision 0

\section{Appendix B}

Report Nu. 1580 - 112542

Page 2 of $\mathrm{G}$

lestacote. Irz.

Novernber 7, 2:002

\section{PURPOSE:}

The ASTM E84 (25 foot tunnel) test method is intended to compare the surface flame spread and smoke developed measuremerats to those obtained from tests of mineral fibor cement board and select grade red oak flooring. The test specimen surface ( 18 inches wide and 24 feet long) is exposed to a flaming fre exposure during the 10 minute test duxation, while flame spread over its surface and dersity of the resulting smoke are measured and recorded. Test results are presented as the computed comparisons to the standard calibration materials.

The furnace is considered under calibration when a 10 minute test of red oak decking will pass flame out the end of the tunnel in five minutes, 30 seconds, plus or minus 15 seconds. Mineral fiber cement board forms the zerc point for both flame spread and smoke developed indexes, while the red oak flooring smoke developed index is set as 100 .

\section{IM. DESCRIPIION OF TEST SFECIMENS}

Speciruer Identification; IrustaCote SD FR (Resin Test No: 2)

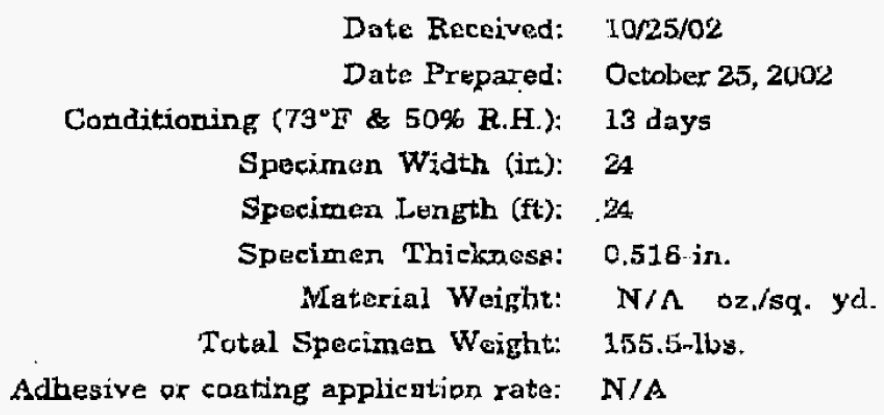

Mounting Method:

The specimen was self supporting and was placed directly on the inner ledges of the tunnel appuratius.

\section{Specimen Description:}

The specimen was described by the clierat as "InstaCoto SE FR (Resin Test \#2)". The specimen consisted of (5) 24 " wide $x 5 \mathrm{ft}$. lonp concrete paneis coated with a blue fire retarded polyurea coating. 


\section{HNF-32146, Revision 0}

Appendix B

Roport No, 15806 - 112542

Page 3 of 6

IristaCote, Inc.

November 7,2002

\section{TEST RESULTS}

The test results, computed on the basis of observed flame front advance and electronic smoke density measurements are presented in the following table. In recogoition of possible variations and limitations of the teat method, the results are computed to the nearest number divisible by five, as outhned in the test method.

While no longer a part of this standard test method, the. Fuel Contributed Value has been computed, and may be found on the computer printout sheet: in the Appendix.

\begin{tabular}{lcc|}
\hline Test Speciunen & $\begin{array}{c}\text { Flame Spread } \\
\text { Index }\end{array}$ & $\begin{array}{c}\text { Smoke Developed } \\
\text { Index }\end{array}$ \\
\hline Mineral Fiber Cement Board & 0 & 0 \\
Red Oak Flooring & $n / a$ & 100 \\
$\begin{array}{l}\text { InstaCote SE FR (Resin Test } \\
\text { No: 2) }\end{array}$ & 20 & 115
\end{tabular}

The data sheets are included in the Appendix. These sheots are actual print-outs of the computerized data system which monitors the ASTM E84 apparatus; and contain all calibration and specimen data needed to calculate the test results.

\section{OBSERVATIONS}

During the test, the specimen wasiobserved to behave in the following manner: Steady ignition began at 0:25 (minssec). The test continued for the 10:00 duration.

After the test, the specimen was observed to be damaged in the following manner: The coating was consumed from $0 \mathrm{ft}$. $10 \mathrm{ft}$. and there was a residual amount of black char. There was a light brown surface discoloration from $10 \mathrm{ft}$ - $24 \mathrm{ft}$. 
HNF-32146, Revision 0

Appendix B

$$
\text { InstaCote, Ine. }
$$

Page 4 of $G$

November 7, 2002

\section{APPENDIX}

\section{DATA SHEITS}

Page B-7 
HNF-32146, Revision 0

Appendix B

\title{
ASTM E84 DATASHEETS
}

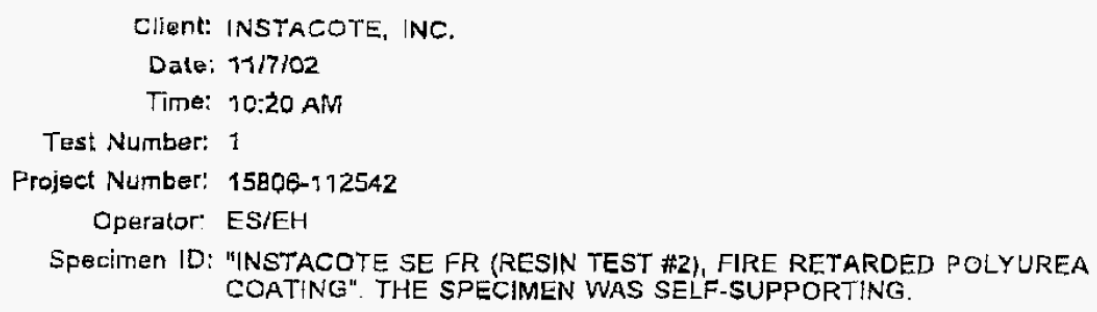

\section{TEST RESULTS}

FLAMESPREAD INDEX; $\quad 20$ SMOKE DEVELOPED INDEX: 115

\section{SPECIMEN DATA}

\author{
Time to Ignition (sac): zs \\ Tlme to Max FS (sec): 195 \\ Maximum FS (feet): 5.0

\section{CALIBRATION DATA}
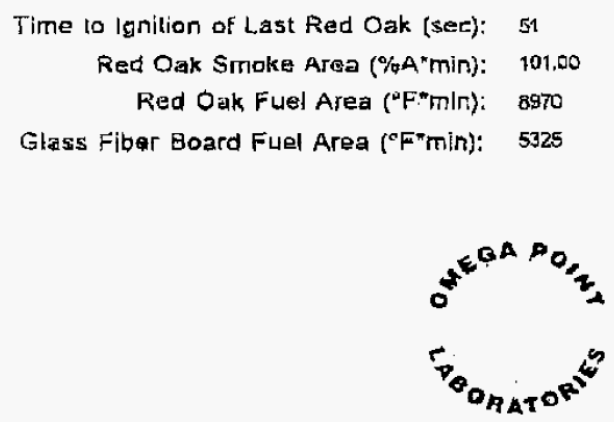

Page B-8 


\section{HNF-32146, Revision 0}

Appendix B

Figure 4. Instacote Flame Spread Testing Data

Project. No: 15806-112542

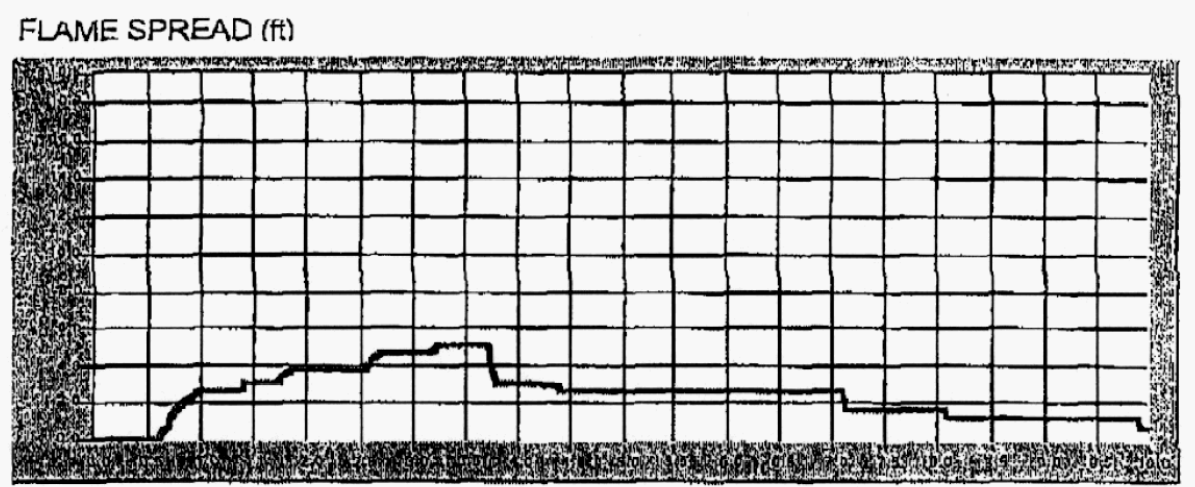

\section{Smoke (\%A)}

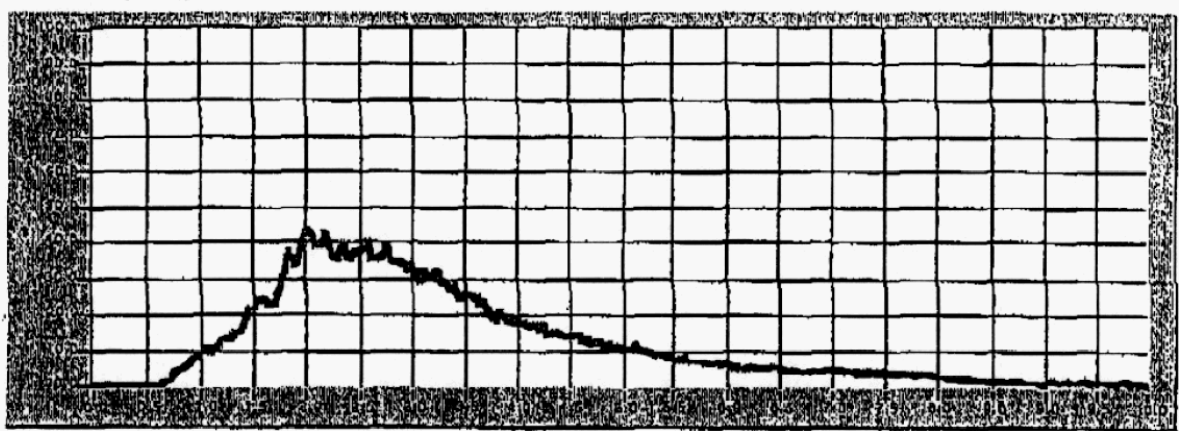

Temperature ( $\left.{ }^{\circ} \mathrm{F}\right)$

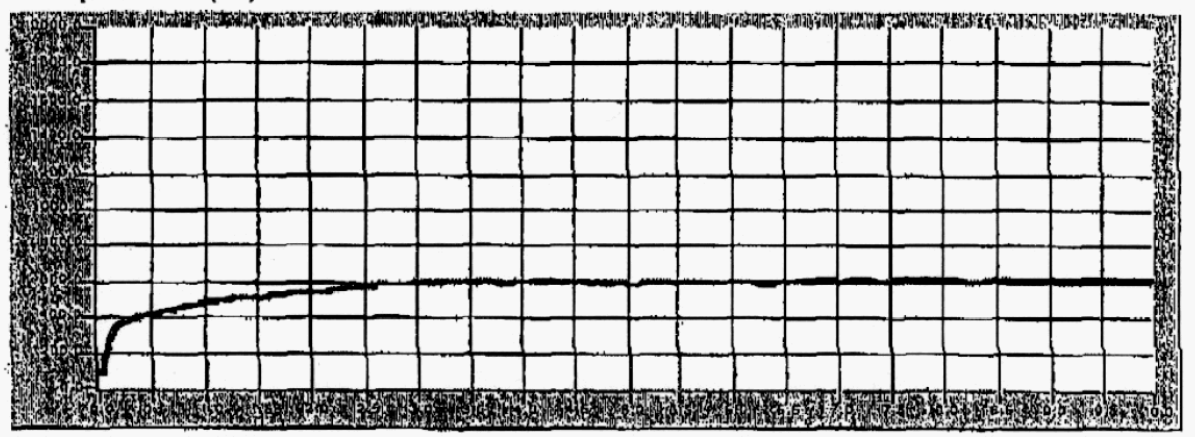

Time (min)

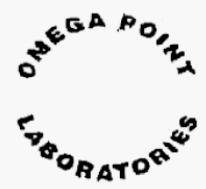

Page B-9 
HNF-32146, Revision 0

Appendix C

\section{APPENDIX C}

HYDROGEN GAS GENERATION CALCULATIONS

Page C-1 
HNF-32146, Revision 0

\section{Appendix C}

\section{$500 \mathrm{~g}$ Source Term with Polyurea}

Performed By: Terry Vail

Checked By: John Woodbury

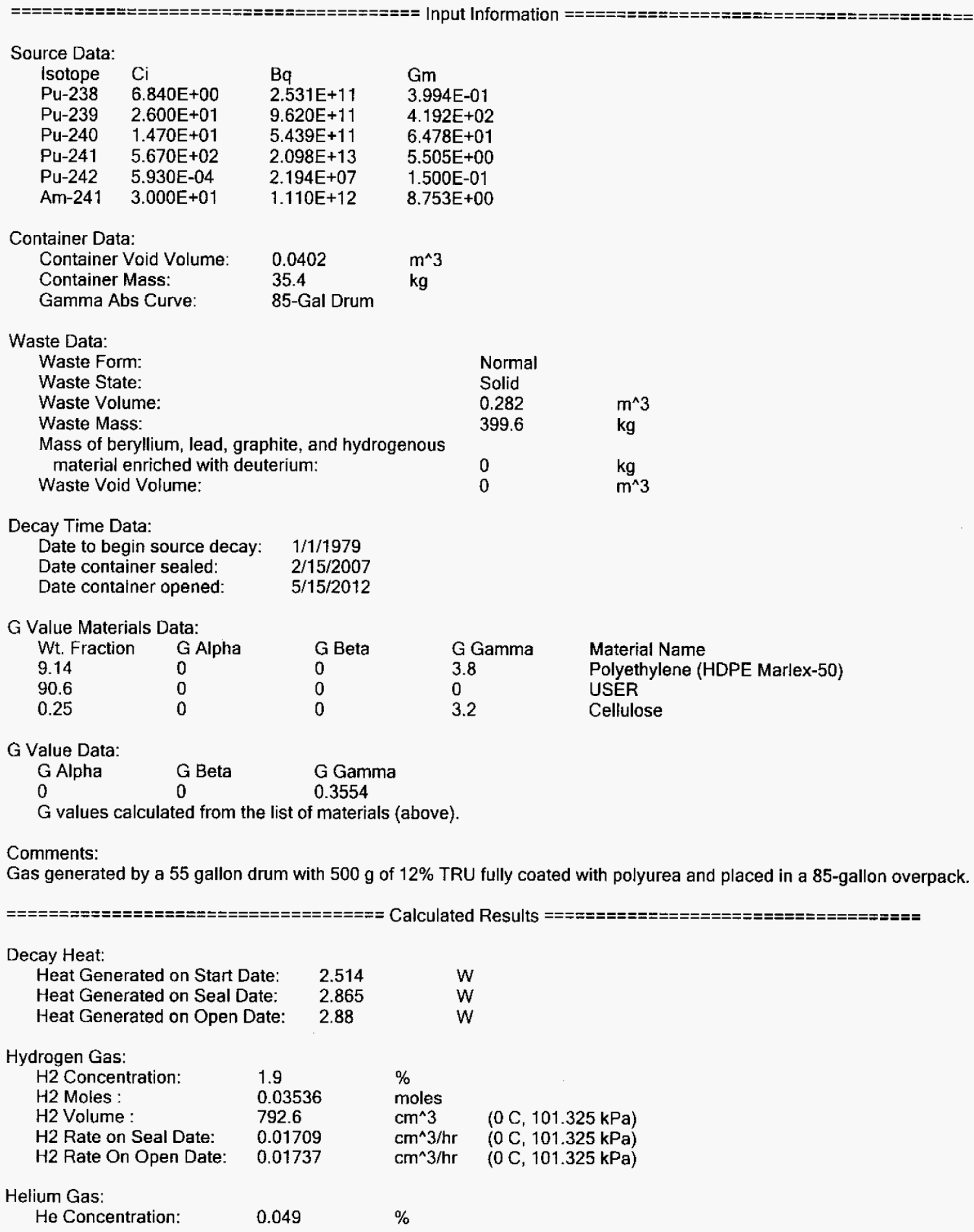


HNF-32146, Revision 0

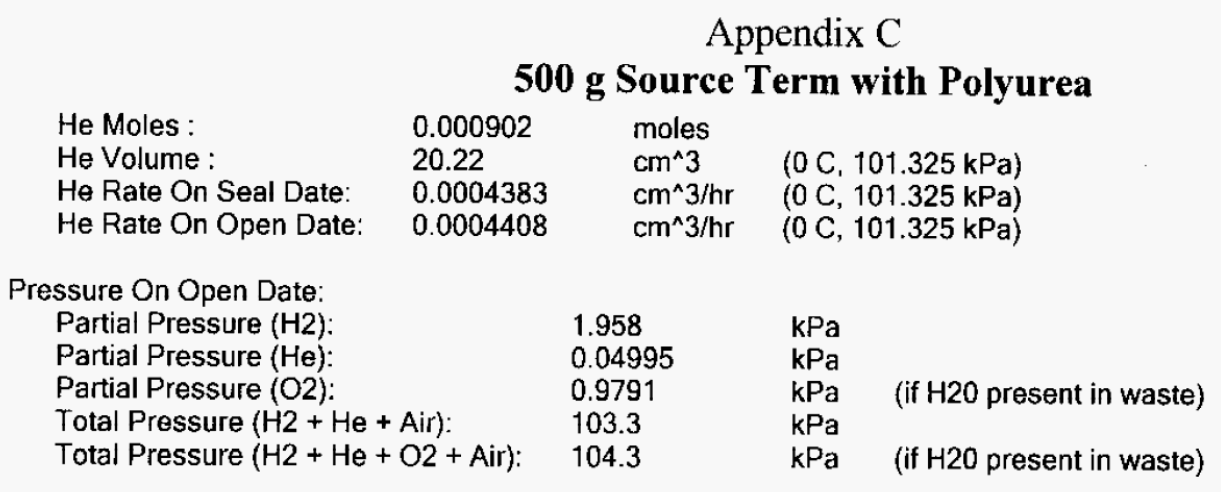

Transportation:

Note: Calculations are made at the end of the user-specified decay time.

Radioactive Determination:

$\begin{array}{llll}\text { Radioactive: } & \text { Yes } & & \text { (ACEMs and ALECs > 1.0) } \\ \text { ACEM Limit Fraction: } & 8330000 & \text { ACEMs } & \text { (Number of ACEMs) } \\ \text { ALEC Limit Fraction: } & 870200000 & \text { ALECs } & \text { (Number of ALECs) } \\ \text { This package is not exempt from the HMR. } & & \end{array}$

Effective A2s for Mixture: $\quad 0.06977$

Type Determination:

\begin{tabular}{|c|c|c|c|}
\hline $\begin{array}{l}\text { Type: } \\
\text { A2 Limit Fraction: }\end{array}$ & $\begin{array}{l}\text { B } \\
3366\end{array}$ & A2s & $\begin{array}{l}(A 2 s>1.0) \\
\text { (Number of A2s) }\end{array}$ \\
\hline nited Quantity Deter & & & \\
\hline Limited Quantity: & No & & (Activity $>0.001 \mathrm{~A} 2$ ) \\
\hline Activity: & $\begin{array}{l}3366 \\
260.8 \\
9.651\end{array}$ & $\begin{array}{l}\mathrm{A} 2 \\
\mathrm{Ci} \\
\mathrm{TBq}\end{array}$ & \\
\hline U-235 Activity: & 0.3331 & $\mathrm{gm}$ & \\
\hline
\end{tabular}

The user must check ensure that all other requirements for LQ in 49 CFR 173.421 are met.

LSA Determination:
LSA-I:
LSA-II:
No
LSA-III:
No
(A2s $>30 \times$ rad limits, and not fissile excepted)
Specific Activity:
No
$0.008423 \quad \mathrm{~A} 2 / \mathrm{gm}$
(A2s/gm $>0.0001$ )
(A2s/gm > 0.002)
$0.0006527 \quad \mathrm{Ci} / \mathrm{gm}$

The user must check ensure that all other requirements for LSA in 49 CFR 173.403 and 49 CFR 173.427 are met.

HRCQ Determination:

$\begin{array}{llll}\text { HRCQ: } & \text { Yes } & & (\mathrm{A} 2 \mathrm{~s}>3000) \\ \text { A2 Limit Fraction: } & 3366 & \mathrm{~A} 2 \mathrm{~s} & \\ \text { Activity: } & 260.8 & \mathrm{Ci} & \\ & 9.651 & \mathrm{TBq}\end{array}$

Fissile Excepted Determination:

$\begin{array}{lll}\text { Fissile Excepted: } & \text { No } & \\ \begin{array}{l}\text { Fissile Quantity: } \\ \begin{array}{l}\text { Beryllium, lead, graphite, and } \\ \text { hydrogenous material }\end{array}\end{array} & 420.6 & \mathrm{gm} \\ \begin{array}{l}\text { enriched with deuterium: } \\ \text { Solid Non-Fissile Quantity: }\end{array} & 0 & \\ \text { Total Uranium Quantity: } & 0.6003 & \mathrm{gm} \\ \text { U-233 Quantity: } & 2.053 \mathrm{E}-06 & \mathrm{gm} \\ \text { U-235 Quantity: } & 0.3331 & \mathrm{gm} \\ \text { Uranium Enrichment: } & 55.49 & \mathrm{gm} \\ \text { Total Plutonium Quantity: } & 485.4 & \mathrm{gm} \\ \text { Pu-239 Quantity: } & 418.9 & \mathrm{gm} \\ \text { Pu-241 Quantity: } & 1.422 & \mathrm{gm}\end{array}$

Container Category Determination: 
Container Category:

TRU Waste Determination: TRU Waste:

TRU Activity:

WIPP Quantities:

FGE Value:

PE-Ci Value:

Reportable Quantity Determination: Reportable Quantity: $\mathrm{RQ}$ Limit Fraction:

Dose-Equivalent Curies: Total ICRP-71/72 DE-Ci: Total FGR-11 DE-Ci:

Source at the Start of Seal Time: Isotope $\mathrm{Hg}-206$

TI-206

TI-207

TI-208

T1-209

TI-210

Pb-209

$\mathrm{Pb}-210$

$\mathrm{Pb}-211$

$\mathrm{Pb}-212$

$\mathrm{Pb}-214$

Bi-210

Bi-211

$\mathrm{Bi}-212$

Bi-213

Bi-214

Bi-215

Po-210

Po-211

Po-212

Po-213

$\mathrm{Po}-214$

Po-215

Po-216

Po-218

At-215

At-217

At-218

At-219

$\mathrm{Rn}-217$

$\mathrm{Rn}-218$

Rn-219

$\mathrm{Rn}-220$

$\mathrm{Rn}-222$

Fr-221

$\mathrm{Fr}-223$

Ra-223

Ra-224

Ra-225

Ra-226

$\mathrm{Ra}-228$

Ac-225

Ac-227

Ac-228

Th-227

HNF-32146, Revision 0

Appendix C

$500 \mathrm{~g}$ Source Term with Polyurea I

Yes

221200

424.1

90.78

Yes

9013

83.84

92.01

$\mathrm{Bq}$

3.531E-08

2.482E-06

$1.889 \mathrm{E}+00$

$5.137 \mathrm{E}-05$

1.334E-02

2.086E-03

$6.175 \mathrm{E}-01$

$1.858 \mathrm{E}+00$

$1.895 \mathrm{E}+00$

1.429E-04

$9.931 \mathrm{E}+00$

$1.853 \mathrm{E}+00$

$1.895 \mathrm{E}+00$

$1.429 \mathrm{E}-04$

$6.175 \mathrm{E}-01$

$9.933 \mathrm{E}+00$

$1.540 \mathrm{E}-06$

1. $724 \mathrm{E}+00$

$5.172 \mathrm{E}-03$

$9.155 \mathrm{E}-05$

6.042E-01

$9.931 \mathrm{E}+00$

$1.895 \mathrm{E}+00$

1.430E-04

$9.933 \mathrm{E}+00$

7.579E-06

6.175E-01

$1.987 \mathrm{E}-03$

1.587E-06

7.410E-05

1.987E-06

$1.895 \mathrm{E}+00$

$1.430 \mathrm{E}-04$

$9.933 \mathrm{E}+00$

6.175E-01

2.646E-02

$1.895 \mathrm{E}+00$

1.430E-04

$6.202 \mathrm{E}-01$

$9.949 \mathrm{E}+00$

1.815E-04

6.175E-01

$1.917 \mathrm{E}+00$

$1.815 \mathrm{E}-04$

1.877E+00
$\mathrm{nCi} / \mathrm{g}$

(TRU activity > $100 \mathrm{nCi} / \mathrm{gm}$ )

(RQs >= 1.0)

RQs (Number of RQs)
$\mathrm{Gm}$

8.520E-27

$3.086 \mathrm{E}-25$

2.681E-19

4.692E-24

8.814E-22

$8.185 \mathrm{E}-23$

3.620E-18

$6.579 \mathrm{E}-13$

2.074E-18

2.781E-21

8.187E-18

4.038E-16

1.247E-19

2.637E-22

8.618E-19

$6.080 \mathrm{E}-18$

$3.521 \mathrm{E}-25$

1.037E-14

1.349E-24

1.395E-32

$1.295 \mathrm{E}-27$

$8.400 \mathrm{E}-25$

1.737E-24

1.073E-26

9.494E-19

3.903E-31

1.037E-23

$1.660 \mathrm{E}-24$

4.497E-26

$2.080 \mathrm{E}-29$

$3.631 \mathrm{E}-29$

3. $936 \mathrm{E}-21$

4.190E-24

$1.746 \mathrm{E}-15$

$9.613 \mathrm{E}-20$

1.849E-20

$9.997 \mathrm{E}-16$

$2.400 \mathrm{E}-20$

4.276E-16

$2.720 \mathrm{E}-10$

$1.799 \mathrm{E}-17$

2.876E-16

7.164E-13

2.195E-21

1.651E-15 
HNF-32146, Revision 0

Appendix C

$500 \mathrm{~g}$ Source Term with Polyurea

$\begin{array}{llll}\text { Th-228 } & 3.869 \mathrm{E}-15 & 1.432 \mathrm{E}-04 & 4.721 \mathrm{E}-18 \\ \text { Th-229 } & 1.687 \mathrm{E}-11 & 6.243 \mathrm{E}-01 & 7.934 \mathrm{E}-11 \\ \text { Th-230 } & 6.522 \mathrm{E}-08 & 2.413 \mathrm{E}+03 & 3.164 \mathrm{E}-06 \\ \text { Th-231 } & 7.197 \mathrm{E}-07 & 2.663 \mathrm{E}+04 & 1.354 \mathrm{E}-12 \\ \text { Th-232 } & 8.481 \mathrm{E}-15 & 3.138 \mathrm{E}-04 & 7.734 \mathrm{E}-08 \\ \text { Th-234 } & 2.578 \mathrm{E}-12 & 9.540 \mathrm{E}-02 & 1.114 \mathrm{E}-16 \\ \text { Pa-231 } & 2.141 \mathrm{E}-10 & 7.921 \mathrm{E}+00 & 4.533 \mathrm{E}-09 \\ \text { Pa-233 } & 3.423 \mathrm{E}-04 & 1.266 \mathrm{E}+07 & 1.649 \mathrm{E}-08 \\ \text { Pa-234 } & 3.352 \mathrm{E}-15 & 1.240 \mathrm{E}-04 & 1.677 \mathrm{E}-21 \\ \text { Pa-234m } & 2.578 \mathrm{E}-12 & 9.540 \mathrm{E}-02 & 3.755 \mathrm{E}-21 \\ \text { U-233 } & 1.977 \mathrm{E}-08 & 7.317 \mathrm{E}+02 & 2.053 \mathrm{E}-06 \\ \text { U-234 } & 4.866 \mathrm{E}-04 & 1.800 \mathrm{E}+07 & 7.827 \mathrm{E}-02 \\ \text { U-235 } & 7.198 \mathrm{E}-07 & 2.663 \mathrm{E}+04 & 3.331 \mathrm{E}-01 \\ \text { U-235m } & 2.598 \mathrm{E}+01 & 9.611 \mathrm{E}+11 & 8.443 \mathrm{E}-07 \\ \text { U-236 } & 1.222 \mathrm{E}-05 & 4.521 \mathrm{E}+05 & 1.889 \mathrm{E}-01 \\ \text { U-237 } & 3.592 \mathrm{E}-03 & 1.329 \mathrm{E}+08 & 4.402 \mathrm{E}-08 \\ \text { U-238 } & 2.587 \mathrm{E}-12 & 9.572 \mathrm{E}-02 & 7.697 \mathrm{E}-06 \\ \text { Np-237 } & 3.437 \mathrm{E}-04 & 1.272 \mathrm{E}+07 & 4.877 \mathrm{E}-01 \\ \text { Pu-238 } & 5.477 \mathrm{E}+00 & 2.026 \mathrm{E}+11 & 3.198 \mathrm{E}-01 \\ \text { Pu-239 } & 2.598 \mathrm{E}+01 & 9.612 \mathrm{E}+11 & 4.189 \mathrm{E}+02 \\ \text { Pu-240 } & 1.466 \mathrm{E}+01 & 5.423 \mathrm{E}+11 & 6.459 \mathrm{E}+01 \\ \text { Pu-241 } & 1.464 \mathrm{E}+02 & 5.418 \mathrm{E}+12 & 1.422 \mathrm{E}+00 \\ \text { Pu-242 } & 5.930 \mathrm{E}-04 & 2.194 \mathrm{E}+07 & 1.500 \mathrm{E}-01 \\ \text { Am-241 } & 4.230 \mathrm{E}+01 & 1.565 \mathrm{E}+12 & 1.234 \mathrm{E}+01 \\ & & & \\ \text { Total Activity: } & 2.608 \mathrm{E}+02 & 9.651 \mathrm{E}+12 & \\ \text { w/o Daughters: } & 2.349 \mathrm{E}+02 & 8.690 \mathrm{E}+12 & \end{array}$

Shipping Papers and Labels:

Isotope Number of A2

- Am-241

1567

* Pu-239

962.2

- Pu-240

542.8

Pu-238

202.8

91.53

Fraction of A2s

Cumulative A2s

1567

0.4654

0.2859

2529

3072

0.06026

3274

3366

Cumulative Fraction of A2s

0.4654

0.7513

0.9125

0.9728

0.02719

* Contains $95 \%$ of the total A2s and must be included per 49 CFR 173.433 .

Radionuclides comprising less than $0.1 \%$ of the total A2s are not shown in the list. 


\section{HNF-32146, Revision 0 \\ Appendix C \\ 500 g Source Term Without Polyurea}

Performed By: Terry Vail

Checked By: John Woodbury

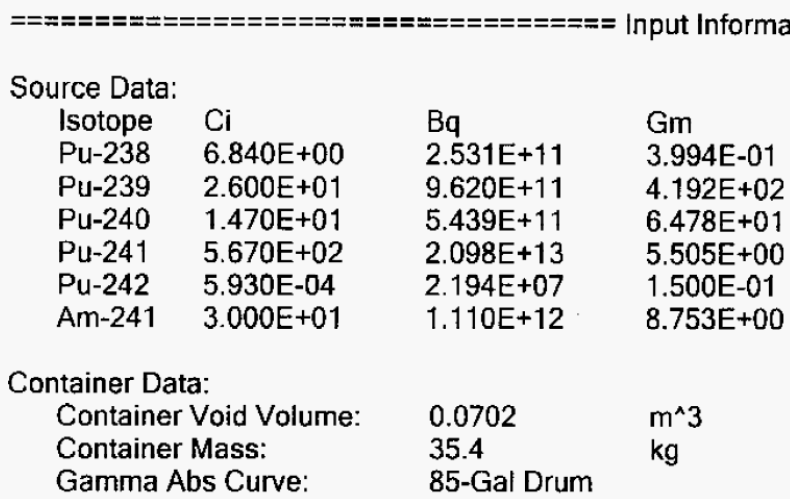

Waste Data:

Waste Form: Norma

Waste State: Solid

Waste Volume: $\quad 0.252$

Waste Mass:

Mass of beryllium, lead, graphite, and hydrogenous material enriched with deuterium:

kg

Waste Void Volume:

$0 \quad \mathrm{~kg}$

Decay Time Data:
Date to begin source decay: $\quad 1 / 1 / 1979$
Date container sealed: $\quad 2 / 15 / 2007$
Date container opened: $\quad 5 / 15 / 2012$

G Value Materials Data:

$\begin{array}{lllll}\text { Wt. Fraction } & \text { G Alpha } & \text { G Beta } & \text { G Gamma } & \text { Material Name } \\ 99.65 & 0 & 0 & 0 & \text { USER } \\ 0.25 & 0 & 0 & 3.2 & \text { Cellulose }\end{array}$

G Value Data:

$\begin{array}{lll}\text { G Alpha } & \text { G Beta } & \text { G Gamma } \\ 0 & 0 & 0.008008 \\ \text { G values calculated from the list of materials (above). }\end{array}$

Comments:

Gas generated by a 55 gallon drum with $500 \mathrm{~g}$ of $12 \%$ TRU without polyurea and placed in a 85-gallon overpack.

\begin{tabular}{|c|c|c|c|c|}
\hline \multicolumn{5}{|l|}{ Decay Heat: } \\
\hline \multirow{3}{*}{\multicolumn{2}{|c|}{$\begin{array}{l}\text { Heat Generated on Start Date: } \\
\text { Heat Generated on Seal Date: } \\
\text { Heat Generated on Open Date: }\end{array}$}} & 2.514 & \multirow{3}{*}{\multicolumn{2}{|c|}{$\begin{array}{l}W \\
W \\
W\end{array}$}} \\
\hline & & 2.865 & & \\
\hline & & 2.88 & & \\
\hline \multicolumn{5}{|l|}{ Hydrogen Gas: } \\
\hline H2 Concentration: & \multirow{2}{*}{\multicolumn{2}{|c|}{$\begin{array}{l}0.026 \\
0.000802\end{array}$}} & \multirow{2}{*}{\multicolumn{2}{|c|}{$\begin{array}{l}\% \\
\text { moles }\end{array}$}} \\
\hline H2 Moles: & & & & \\
\hline H2 Volume : & \multicolumn{2}{|c|}{17.98} & $\mathrm{~cm}^{\wedge} 3$ & $(0 \mathrm{C}, 101.325 \mathrm{kPa})$ \\
\hline H2 Rate on Seal Date: & \multirow{2}{*}{\multicolumn{2}{|c|}{$\begin{array}{l}0.0003876 \\
0.0003938\end{array}$}} & $\mathrm{~cm}^{\wedge} 3 / \mathrm{hr}$ & $(0 \mathrm{C}, 101.325 \mathrm{kPa})$ \\
\hline H2 Rate On Open Date: & & & $\mathrm{cm}^{\wedge} 3 / \mathrm{hr}$ & $(0 \mathrm{C}, 101.325 \mathrm{kPa})$ \\
\hline \multicolumn{5}{|l|}{ Helium Gas: } \\
\hline $\begin{array}{l}\text { He Concentration: } \\
\text { He Moles: }\end{array}$ & \multicolumn{2}{|c|}{$\begin{array}{l}0.029 \\
0.000902\end{array}$} & \multicolumn{2}{|l|}{$\begin{array}{l}\% \\
\text { moles }\end{array}$} \\
\hline
\end{tabular}




\section{HNF-32146, Revision 0}

\section{Appendix C \\ $500 \mathrm{~g}$ Source Term Without Polyurea}

\begin{tabular}{|c|c|c|c|c|}
\hline $\begin{array}{l}\text { He Volume: } \\
\text { He Rate On Seal Date: } \\
\text { He Rate On Open Date: }\end{array}$ & $\begin{array}{l}20.22 \\
0.0004383 \\
0.0004408\end{array}$ & $\begin{array}{l}\mathrm{cm}^{\wedge} 3 \\
\mathrm{~cm}^{\wedge} 3 / \mathrm{hr} \\
\mathrm{cm}^{\wedge} 3 / \mathrm{hr}\end{array}$ & \multicolumn{2}{|c|}{$\begin{array}{l}(0 \mathrm{C}, 101.325 \mathrm{kPa}) \\
(0 \mathrm{C}, 101.325 \mathrm{kPa}) \\
(0 \mathrm{C}, 101.325 \mathrm{kPa})\end{array}$} \\
\hline \multicolumn{5}{|l|}{ ssure On Open Date: } \\
\hline Partial Pressure $(\mathrm{H} 2)$ : & & 0.02593 & $\mathrm{kPa}$ & \\
\hline Partial Pressure (He): & & 0.02916 & $\mathrm{kPa}$ & \\
\hline Partial Pressure (O2): & & 0.01297 & $\mathrm{kPa}$ & (if $\mathrm{H} 20$ present in waste) \\
\hline Total Pressure $(\mathrm{H} 2+\mathrm{He}$ & & 101.4 & $\mathrm{kPa}$ & \\
\hline Total Pressure $(\mathrm{H} 2+\mathrm{He}$ & , & 101.4 & $\mathrm{kPa}$ & (if $\mathrm{H} 20$ present in waste) \\
\hline
\end{tabular}

Transportation:

Note: Calculations are made at the end of the user-specified decay time.

Radioactive Determination:

$\begin{array}{llll}\text { Radioactive: } & \text { Yes } & & \text { (ACEMs and ALECs > 1.0) } \\ \text { ACEM Limit Fraction: } & 9168000 & \text { ACEMs } & \text { (Number of ACEMs) } \\ \text { ALEC Limit Fraction: } & 870200000 & \text { ALECs } & \text { (Number of ALECs) } \\ \text { This package is not exempt from the HMR } & & \end{array}$
This package is not exempt from the HMR.

Effective A2s for Mixture:

0.06977

$\mathrm{Ci}$

Type Determination:
Type:
B
A2 Limit Fraction:
$(\mathrm{A} 2 \mathrm{~s}>1.0)$
(Number of A2s)

Limited Quantity Determination:

\begin{tabular}{llll} 
Limited Quantity: & No & & (Activity > 0.001 A2) \\
Activity: & 3366 & $\mathrm{~A} 2$ & \\
& 260.8 & $\mathrm{Ci}$ & \\
U-235 Activity: & 9.651 & $\mathrm{TBq}$ & \\
\hline
\end{tabular}

The user must check ensure that all other requirements for LQ in 49 CFR 173.421 are met.

LSA Determination:
LSA-I:
No
LSA-II:
LSA-III:
Specific Activity:
No
No
$0.009271 \quad \mathrm{~A} 2 / \mathrm{gm}$
(A2s $>30 \times$ rad limits, and not fissile excepted)
(A2s/gm $>0.0001$ )
(A2s/gm > 0.002)
$0.0007184 \quad \mathrm{Ci} / \mathrm{gm}$ met.

The user must check ensure that all other requirements for LSA in 49 CFR 173.403 and 49 CFR 173.427 are

HRCQ Determination:

HRCQ: Yes

A2 Limit Fraction: $\quad 3366$

Activity: $\quad 260.8$

9.651

A2s

$\mathrm{Ci}$

$\mathrm{TBq}$

Fissile Excepted Determination:

Fissile Excepted:

Fissile Quantity:

Beryllium, lead, graphite, and

hydrogenous material

enriched with deuterium:

Solid Non-Fissile Quantity:

Total Uranium Quantity:

U-233 Quantity:

U-235 Quantity:

Uranium Enrichment:

Total Plutonium Quantity:

Pu-239 Quantity:

Pu-241 Quantity:

No

420.6

0

398000

0.6003

2.053E-06

0.3331

55.49

485.4

418.9

1.422
(A2s > 3000)

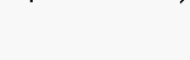

Package is fissile 
HNF-32146, Revision 0

\section{Appendix C \\ $500 \mathrm{~g}$ Source Term Without Polyurea}

Container Category Determination:

Container Category:

TRU Waste Determination:

TRU Waste:

TRU Activity:

WIPP Quantities:

FGE Value:

PE-Ci Value:

Reportable Quantity Determination:

Reportable Quantity:

$R Q$ Limit Fraction:

Dose-Equivalent Curies:

Total ICRP-71/72 DE-Ci

Total FGR-11 DE-Ci:

I

Yes

243500

Source at the Start of Seal Time:

\begin{tabular}{|c|c|c|c|}
\hline Isotope & $\mathrm{Ci}$ & $\mathrm{Bq}$ & $\mathrm{Gm}$ \\
\hline $\mathrm{Hg}-206$ & $9.543 \mathrm{E}-19$ & $3.531 \mathrm{E}-08$ & $8.520 \mathrm{E}-27$ \\
\hline TI-206 & $6.708 \mathrm{E}-17$ & $2.482 \mathrm{E}-06$ & $3.086 \mathrm{E}-25$ \\
\hline TI-207 & 5.107E-11 & $1.889 E+00$ & $2.681 \mathrm{E}-19$ \\
\hline TI-208 & $1.388 \mathrm{E}-15$ & $5.137 \mathrm{E}-05$ & $4.692 \mathrm{E}-24$ \\
\hline TI-209 & $3.605 \mathrm{E}-13$ & $1.334 \mathrm{E}-02$ & $8.814 \mathrm{E}-22$ \\
\hline TI-210 & $5.638 \mathrm{E}-14$ & $2.086 \mathrm{E}-03$ & $8.185 \mathrm{E}-23$ \\
\hline Pb-209 & $1.669 \mathrm{E}-11$ & $6.175 \mathrm{E}-01$ & $3.620 \mathrm{E}-18$ \\
\hline $\mathrm{Pb}-210$ & $5.023 \mathrm{E}-11$ & $1.858 E+00$ & $6.579 \mathrm{E}-13$ \\
\hline $\mathrm{Pb}-211$ & $5.121 \mathrm{E}-11$ & $1.895 E+00$ & $2.074 \mathrm{E}-18$ \\
\hline $\mathrm{Pb}-212$ & $3.863 E-15$ & $1.429 \mathrm{E}-04$ & $2.781 \mathrm{E}-21$ \\
\hline $\mathrm{Pb}-214$ & $2.684 \mathrm{E}-10$ & $9.931 \mathrm{E}+00$ & $8.187 E-18$ \\
\hline $\mathrm{Bi}-210$ & $5.009 \mathrm{E}-11$ & $1.853 \mathrm{E}+00$ & $4.038 \mathrm{E}-16$ \\
\hline $\mathrm{Bi}-211$ & $5.121 \mathrm{E}-11$ & $1.895 \mathrm{E}+00$ & $1.247 \mathrm{E}-19$ \\
\hline $\mathrm{Bi}-212$ & $3.863 \mathrm{E}-15$ & $1.429 \mathrm{E}-04$ & $2.637 \mathrm{E}-22$ \\
\hline $\mathrm{Bi}-213$ & $1.669 \mathrm{E}-11$ & $6.175 \mathrm{E}-01$ & $8.618 \mathrm{E}-19$ \\
\hline Bi-214 & $2.685 \mathrm{E}-10$ & $9.933 E+00$ & $6.080 \mathrm{E}-18$ \\
\hline Bi-215 & $4.161 \mathrm{E}-17$ & $1.540 \mathrm{E}-06$ & $3.521 \mathrm{E}-25$ \\
\hline Po-210 & $4.658 \mathrm{E}-11$ & $1.724 \mathrm{E}+00$ & $1.037 \mathrm{E}-14$ \\
\hline Рo-211 & $1.398 \mathrm{E}-13$ & $5.172 \mathrm{E}-03$ & $1.349 \mathrm{E}-24$ \\
\hline Po-212 & $2.474 \mathrm{E}-15$ & $9.155 \mathrm{E}-05$ & $1.395 \mathrm{E}-32$ \\
\hline Po-213 & $1.633 \mathrm{E}-11$ & $6.042 E-01$ & $1.295 \mathrm{E}-27$ \\
\hline Рo-214 & $2.684 \mathrm{E}-10$ & $9.931 E+00$ & $8.400 \mathrm{E}-25$ \\
\hline Po-215 & $5.121 \mathrm{E}-11$ & $1.895 \mathrm{E}+00$ & 1.737E-24 \\
\hline Po-216 & 3.864E-15 & $1.430 \mathrm{E}-04$ & $1.073 \mathrm{E}-26$ \\
\hline Po-218 & $2.685 \mathrm{E}-10$ & $9.933 \mathrm{E}+00$ & $9.494 \mathrm{E}-19$ \\
\hline At-215 & $2.048 \mathrm{E}-16$ & 7.579E-06 & $3.903 \mathrm{E}-31$ \\
\hline At-217 & $1.669 \mathrm{E}-11$ & $6.175 \mathrm{E}-01$ & 1.037E-23 \\
\hline At-218 & $5.369 \mathrm{E}-14$ & 1.987E-03 & $1.660 \mathrm{E}-24$ \\
\hline At- 219 & $4.290 \mathrm{E}-17$ & 1.587E-06 & 4.497E-26 \\
\hline $\mathrm{Rn}-217$ & $2.003 E-15$ & 7.410E-05 & $2.080 \mathrm{E}-29$ \\
\hline Rn-218 & 5.369E-17 & $1.987 \mathrm{E}-06$ & $3.631 \mathrm{E}-29$ \\
\hline$R n-219$ & $5.121 \mathrm{E}-11$ & $1.895 \mathrm{E}+00$ & $3.936 \mathrm{E}-21$ \\
\hline $\mathrm{Rn}-220$ & $3.864 \mathrm{E}-15$ & $1.430 \mathrm{E}-04$ & 4.190E-24 \\
\hline $\mathrm{Rn}-222$ & $2.685 \mathrm{E}-10$ & $9.933 E+00$ & $1.746 \mathrm{E}-15$ \\
\hline Fr-221 & $1.669 \mathrm{E}-11$ & $6.175 \mathrm{E}-01$ & $9.613 \mathrm{E}-20$ \\
\hline Fr-223 & $7.150 \mathrm{E}-13$ & $2.646 \mathrm{E}-02$ & $1.849 \mathrm{E}-20$ \\
\hline $\mathrm{Ra}-223$ & $5.121 \mathrm{E}-11$ & $1.895 \mathrm{E}+00$ & 9.997E-16 \\
\hline Ra-224 & $3.864 \mathrm{E}-15$ & $1.430 \mathrm{E}-04$ & $2.400 \mathrm{E}-20$ \\
\hline Ra-225 & $1.676 \mathrm{E}-11$ & $6.202 \mathrm{E}-01$ & $4.276 \mathrm{E}-16$ \\
\hline $\mathrm{Ra}-226$ & $2.689 \mathrm{E}-10$ & $9.949 \mathrm{E}+00$ & $2.720 \mathrm{E}-10$ \\
\hline $\mathrm{Ra}-228$ & 4.905E-15 & $1.815 \mathrm{E}-04$ & 1.799E-17 \\
\hline AC-225 & $1.669 \mathrm{E}-11$ & $6.175 \mathrm{E}-01$ & $2.876 \mathrm{E}-16$ \\
\hline Ac-227 & $5.181 \mathrm{E}-11$ & 1.917E+00 & $7.164 \mathrm{E}-13$ \\
\hline
\end{tabular}

424.1

90.78

83.84

92.01

Yes

9013

$\mathrm{nCi} / \mathrm{g}$
(TRU activity > $100 \mathrm{nCi} / \mathrm{gm}$ )

(RQs $>=1.0)$

RQs (Number of RQs) 
HNF-32146, Revision 0

\section{Appendix C \\ $500 \mathrm{~g}$ Source Term Without Polyurea}

\begin{tabular}{|c|c|c|c|c|}
\hline Ac-228 & 4.904E-15 & $1.815 \mathrm{E}-04$ & 2.195E-21 & \\
\hline Th-227 & $5.072 \mathrm{E}-11$ & 1.877E+00 & 1.651E-15 & \\
\hline Th-228 & 3.869E-15 & $1.432 \mathrm{E}-04$ & $4.721 \mathrm{E}-18$ & \\
\hline Th-229 & $1.687 \mathrm{E}-11$ & $6.243 \mathrm{E}-01$ & $7.934 \mathrm{E}-11$ & \\
\hline Th-230 & 6.522E-08 & $2.413 E+03$ & $3.164 \mathrm{E}-06$ & \\
\hline Th-231 & 7.197E-07 & $2.663 \mathrm{E}+04$ & 1.354E-12 & \\
\hline Th-232 & $8.481 \mathrm{E}-15$ & $3.138 \mathrm{E}-04$ & 7.734E-08 & \\
\hline Th-234 & $2.578 \mathrm{E}-12$ & $9.540 \mathrm{E}-02$ & $1.114 \mathrm{E}-16$ & \\
\hline $\mathrm{Pa}-231$ & $2.141 \mathrm{E}-10$ & $7.921 \mathrm{E}+00$ & 4.533E-09 & \\
\hline $\mathrm{Pa}-233$ & 3.423E-04 & $1.266 E+07$ & 1.649E-08 & \\
\hline $\mathrm{Pa}-234$ & 3.352E-15 & 1.240E-04 & 1.677E-21 & \\
\hline $\mathrm{Pa}-234 \mathrm{~m}$ & $2.578 \mathrm{E}-12$ & $9.540 \mathrm{E}-02$ & $3.755 \mathrm{E}-21$ & \\
\hline$U-233$ & 1.977E-08 & 7.317E+02 & 2.053E-06 & \\
\hline U-234 & 4.866E-04 & $1.800 \mathrm{E}+07$ & $\begin{array}{l}\text { 7.827E-02 } \\
3.331 \mathrm{~F}-01\end{array}$ & \\
\hline U-235 & $\begin{array}{l}7.198 \mathrm{E}-07 \\
2.598 \mathrm{E}+01\end{array}$ & $2.663 \mathrm{E}+04$ & $\begin{array}{l}3.331 \mathrm{E}-01 \\
8.443 \mathrm{E}-07\end{array}$ & \\
\hline $\begin{array}{l}\text { U-235m } \\
\text { U-236 }\end{array}$ & $\begin{array}{l}2.598 \mathrm{E}+01 \\
1.222 \mathrm{E}-05\end{array}$ & $\begin{array}{l}9.611 \mathrm{E}+11 \\
4.521 \mathrm{E}+05\end{array}$ & $\begin{array}{l}8.443 \mathrm{E}-07 \\
1.889 \mathrm{E}-01\end{array}$ & \\
\hline U-237 & $3.592 \mathrm{E}-03$ & $1.329 E+08$ & 4.402E-08 & \\
\hline U-238 & $2.587 \mathrm{E}-12$ & $9.572 \mathrm{E}-02$ & 7.697E-06 & \\
\hline $\mathrm{Np}-237$ & 3.437E-04 & $1.272 E+07$ & 4.877E-01 & \\
\hline Pu-238 & $5.477 \mathrm{E}+00$ & $2.026 \mathrm{E}+11$ & 3.198E-01 & \\
\hline Pu-239 & $2.598 \mathrm{E}+01$ & $9.612 E+11$ & $4.189 E+02$ & \\
\hline Pu-240 & $1.466 \mathrm{E}+01$ & $5.423 E+11$ & $6.459 \mathrm{E}+01$ & \\
\hline Pu-241 & $1.464 \mathrm{E}+02$ & $5.418 \mathrm{E}+12$ & $1.422 E+00$ & \\
\hline $\begin{array}{l}\mathrm{Pu}-242 \\
\mathrm{Am}-241\end{array}$ & 5.930E-04 & $2.194 \mathrm{E}+07$ & $1.500 \mathrm{E}-01$ & \\
\hline & . & 1.0000 . 12 & 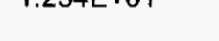 & \\
\hline $\begin{array}{l}\text { Total Activity: } \\
\text { w/o Daughters: }\end{array}$ & $\begin{array}{l}2.608 \mathrm{E}+02 \\
2.349 \mathrm{E}+02\end{array}$ & $\begin{array}{l}9.651 \mathrm{E}+12 \\
8.690 \mathrm{E}+12\end{array}$ & & \\
\hline \multicolumn{5}{|c|}{ hipping Papers and Labeis: } \\
\hline Isotope & \multirow{2}{*}{$\begin{array}{l}\text { Number of A2s } \\
1567\end{array}$} & Fraction of $\mathrm{A} 2 \mathrm{~s}$ & Cumulative A2s & Cumulative Fraction of $\mathrm{A} 2 \mathrm{~s}$ \\
\hline Am-241 & & 0.4654 & 1567 & 0.4654 \\
\hline Pu-239 & 962.2 & 0.2859 & 2529 & 0.7513 \\
\hline Pu-240 & 542.8 & 0.1613 & 3072 & 0.9125 \\
\hline Pu-238 & 202.8 & 0.06026 & 3274 & 0.9728 \\
\hline Pu-241 & 91.53 & 0.02719 & 3366 & 1 \\
\hline
\end{tabular}


HNF-32146, Revision 0

Appendix C

\section{$200 \mathrm{~g}$ Source Term With Polyurea}

Performed By: Terry Vail

Checked By: John Woodbury

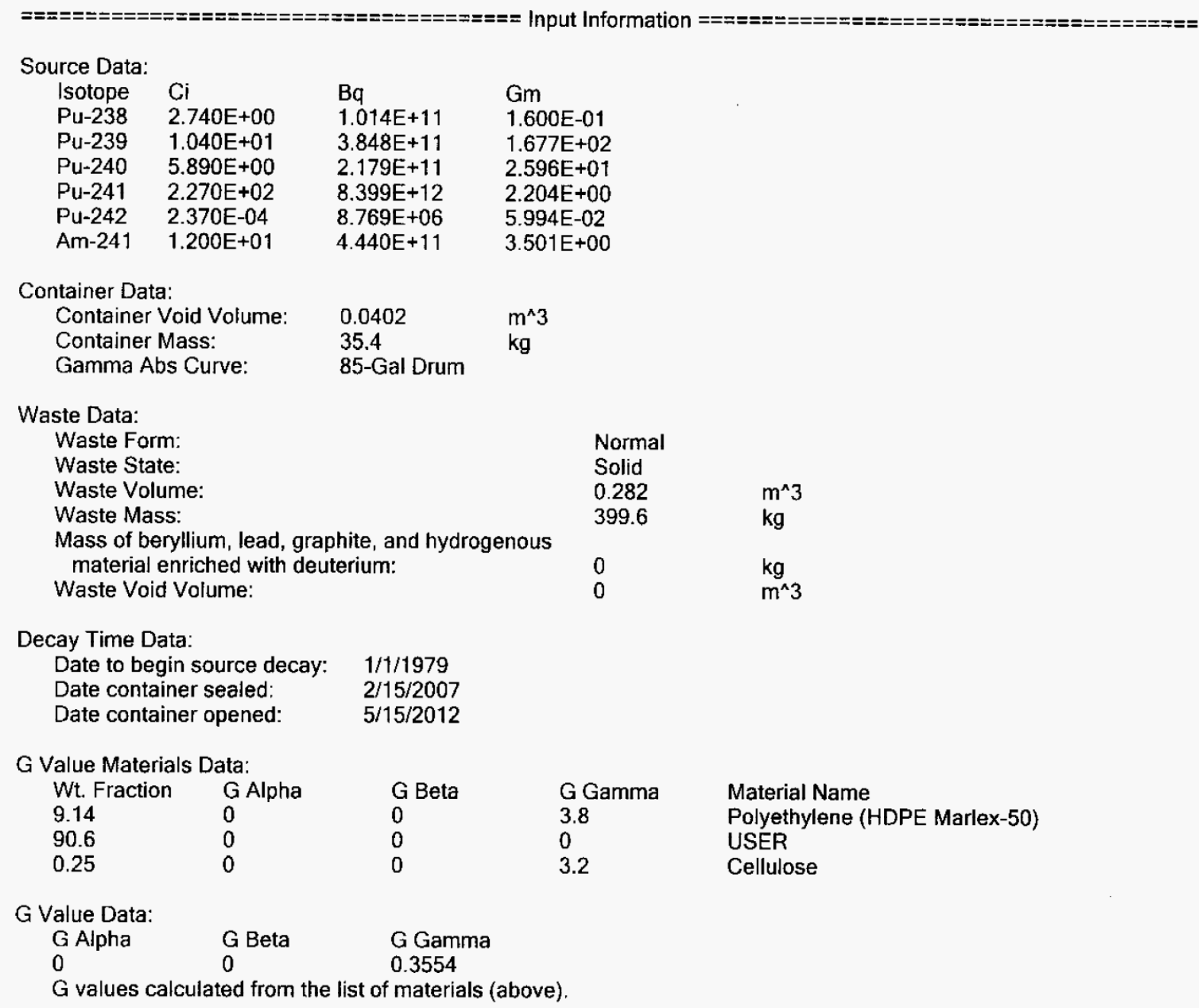

Comments:

Gas generated by a 55 gallon drum with $200 \mathrm{~g}$ of $12 \%$ TRU fully coated with polyurea and placed in a $85-$ gallon overpack.

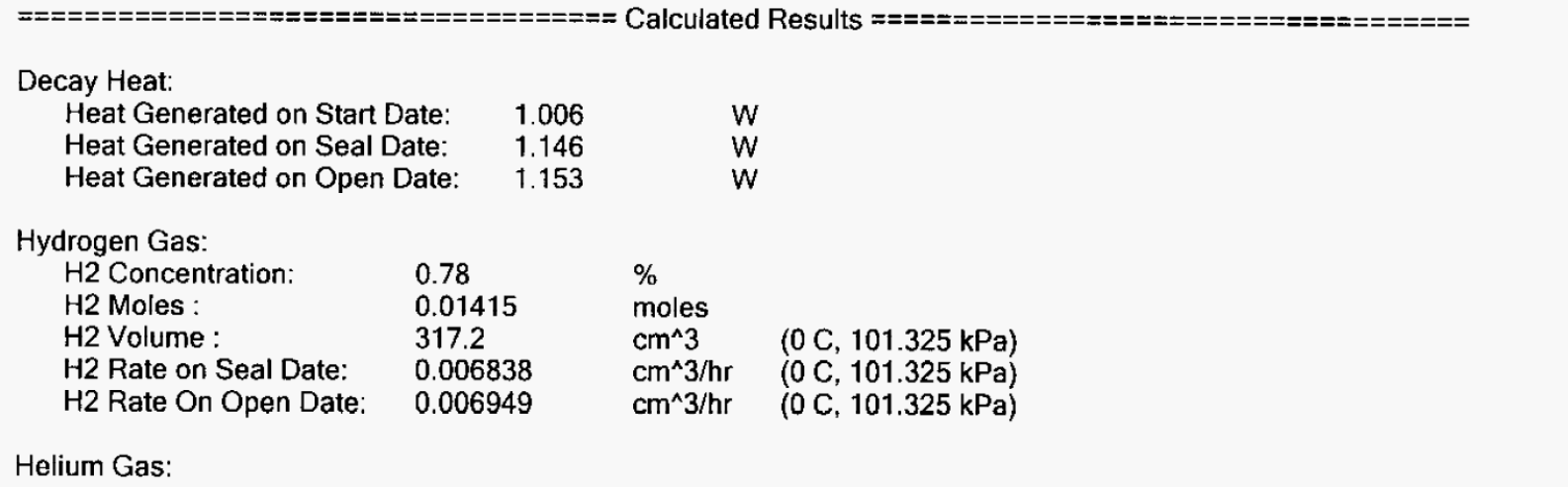


HNF-32146, Revision 0

\section{Appendix C \\ 200 g Source Term With Polyurea}

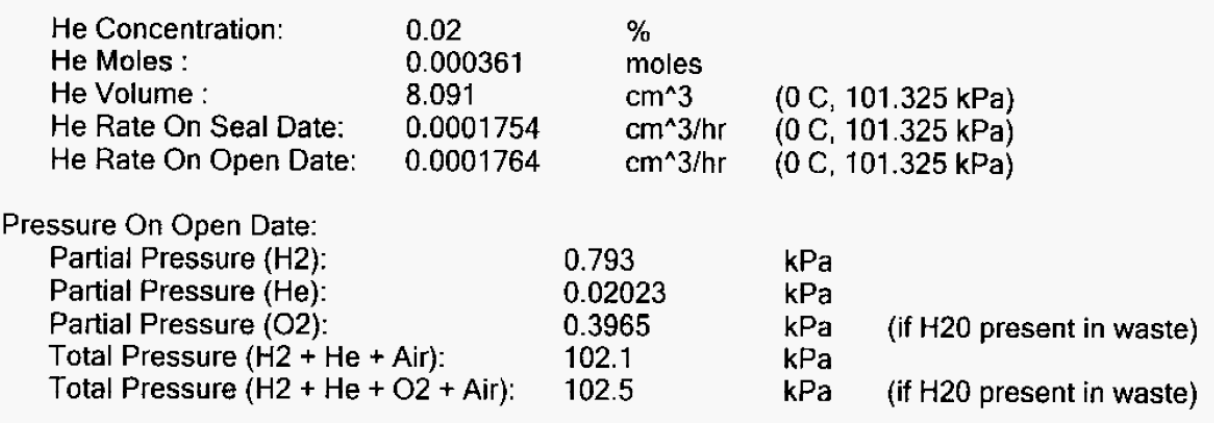

Transportation:

Note: Calculations are made at the end of the user-specified decay time.

Radioactive Determination:

$\begin{array}{llll}\text { Radioactive: } & \text { Yes } & & \text { (ACEMs and ALECs > 1.0) } \\ \text { ACEM Limit Fraction: } & 3334000 & \text { ACEMs } & \text { (Number of ACEMs) } \\ \text { ALEC Limit Fraction: } & 348500000 & \text { ALECs } & \text { (Number of ALECs) } \\ \text { This package is not exempt from the HMR. } & & \end{array}$

Effective A2s for Mixture:

0.06979

$\mathrm{Ci}$

Type Determination:

$\begin{array}{llll}\text { Type: } & \text { B } & & (\text { A2s }>1.0) \\ \text { A2 Limit Fraction: } & 1347 & \text { A2s } & \text { (Number of A2s) }\end{array}$

Limited Quantity Determination:

$\begin{array}{llll}\text { Limited Quantity: } & \text { No } & & \text { (Activity > 0.001 A2) } \\ \text { Activity: } & 1347 & \mathrm{~A} 2 & \\ & 104.4 & \mathrm{Ci} & \\ & 3.863 & \mathrm{TBq} & \\ \text { U-235 Activity: } & 0.1332 & \mathrm{gm} & \end{array}$

The user must check ensure that all other requirements for LQ in 49 CFR 173.421 are met.

LSA Determination:
LSA-I: No
LSA-II: No
LSA-III: No
Specific Activity: $\quad 0.003371 \quad$ A2/gm
(Fissile excepted, but $\mathrm{A} 2 \mathrm{~s}>30 \times$ rad limits)
(A2s/gm >0.0001)
$0.0002613 \quad \mathrm{Ci} / \mathrm{gm}$

The user must check ensure that all other requirements for LSA in 49 CFR 173.403 and 49 CFR 173.427 are met.

HRCQ Determination:

HRCQ:

A2 Limit Fraction:

Activity:

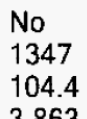

Fissile Excepted Determination: Fissile Excepted: material > 3.365E+05 grams)

Fissile Quantity:

Beryllium, lead, graphite, and

hydrogenous material enriched with deuterium:

Solid Non-Fissile Quantity:

Total Uranium Quantity:

U-233 Quantity:

U-235 Quantity:

Uranium Enrichment:

Total Plutonium Quantity:
1347

3.863

Yes

168.3

$$
\begin{aligned}
& \mathrm{A} 2 \mathrm{~s} \\
& \mathrm{Ci} \\
& \mathrm{TBq}
\end{aligned}
$$


HNF-32146, Revision 0

Appendix $\mathrm{C}$

200 g Source Term With Polyurea

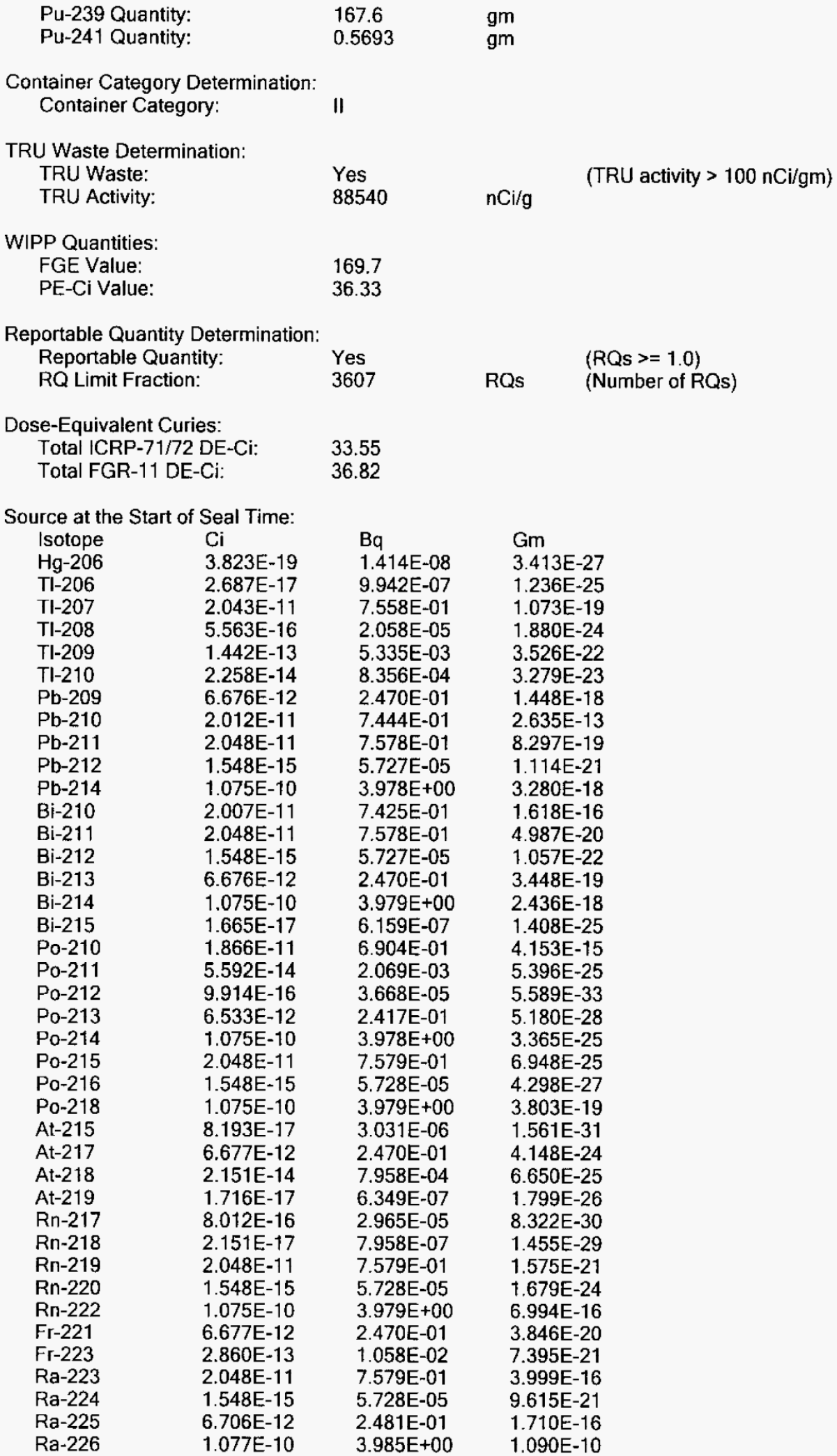


HNF-32146, Revision 0

Appendix C

$200 \mathrm{~g}$ Source Term With Polyurea

$\begin{array}{llll}\text { Ra-228 } & 1.965 \mathrm{E}-15 & 7.271 \mathrm{E}-05 & 7.208 \mathrm{E}-18 \\ \text { Ac-225 } & 6.677 \mathrm{E}-12 & 2.470 \mathrm{E}-01 & 1.151 \mathrm{E}-16 \\ \text { Ac-227 } & 2.073 \mathrm{E}-11 & 7.668 \mathrm{E}-01 & 2.866 \mathrm{E}-13 \\ \text { Ac-228 } & 1.965 \mathrm{E}-15 & 7.270 \mathrm{E}-05 & 8.793 \mathrm{E}-22 \\ \text { Th-227 } & 2.029 \mathrm{E}-11 & 7.507 \mathrm{E}-01 & 6.603 \mathrm{E}-16 \\ \text { Th-228 } & 1.550 \mathrm{E}-15 & 5.736 \mathrm{E}-05 & 1.892 \mathrm{E}-18 \\ \text { Th-229 } & 6.750 \mathrm{E}-12 & 2.497 \mathrm{E}-01 & 3.174 \mathrm{E}-11 \\ \text { Th-230 } & 2.613 \mathrm{E}-08 & 9.667 \mathrm{E}+02 & 1.268 \mathrm{E}-06 \\ \text { Th-231 } & 2.879 \mathrm{E}-07 & 1.065 \mathrm{E}+04 & 5.417 \mathrm{E}-13 \\ \text { Th-232 } & 3.398 \mathrm{E}-15 & 1.257 \mathrm{E}-04 & 3.099 \mathrm{E}-08 \\ \text { Th-234 } & 1.030 \mathrm{E}-12 & 3.813 \mathrm{E}-02 & 4.451 \mathrm{E}-17 \\ \text { Pa-231 } & 8.564 \mathrm{E}-11 & 3.169 \mathrm{E}+00 & 1.813 \mathrm{E}-09 \\ \text { Pa-233 } & 1.369 \mathrm{E}-04 & 5.066 \mathrm{E}+06 & 6.598 \mathrm{E}-09 \\ \text { Pa-234 } & 1.340 \mathrm{E}-15 & 4.956 \mathrm{E}-05 & 6.703 \mathrm{E}-22 \\ \text { Pa-234m } & 1.030 \mathrm{E}-12 & 3.813 \mathrm{E}-02 & 1.501 \mathrm{E}-21 \\ \text { U-233 } & 7.911 \mathrm{E}-09 & 2.927 \mathrm{E}+02 & 8.212 \mathrm{E}-07 \\ \text { U-234 } & 1.949 \mathrm{E}-04 & 7.212 \mathrm{E}+06 & 3.135 \mathrm{E}-02 \\ \text { U-235 } & 2.879 \mathrm{E}-07 & 1.065 \mathrm{E}+04 & 1.332 \mathrm{E}-01 \\ \text { U-235m } & 1.039 \mathrm{E}+01 & 3.844 \mathrm{E}+11 & 3.377 \mathrm{E}-07 \\ \text { U-236 } & 4.896 \mathrm{E}-06 & 1.812 \mathrm{E}+05 & 7.570 \mathrm{E}-02 \\ \text { U-237 } & 1.438 \mathrm{E}-03 & 5.322 \mathrm{E}+07 & 1.762 \mathrm{E}-08 \\ \text { U-238 } & 1.034 \mathrm{E}-12 & 3.826 \mathrm{E}-02 & 3.076 \mathrm{E}-06 \\ \text { Np-237 } & 1.375 \mathrm{E}-04 & 5.088 \mathrm{E}+06 & 1.951 \mathrm{E}-01 \\ \text { Pu-238 } & 2.194 \mathrm{E}+00 & 8.117 \mathrm{E}+10 & 1.281 \mathrm{E}-01 \\ \text { Pu-239 } & 1.039 \mathrm{E}+01 & 3.845 \mathrm{E}+11 & 1.676 \mathrm{E}+02 \\ \text { Pu-240 } & 5.873 \mathrm{E}+00 & 2.173 \mathrm{E}+11 & 2.588 \mathrm{E}+01 \\ \text { Pu-241 } & 5.863 \mathrm{E}+01 & 2.169 \mathrm{E}+12 & 5.693 \mathrm{E}-01 \\ \text { Pu-242 } & 2.370 \mathrm{E}-04 & 8.769 \mathrm{E}+06 & 5.993 \mathrm{E}-02 \\ \text { Am-241 } & 1.692 \mathrm{E}+01 & 6.262 \mathrm{E}+11 & 4.938 \mathrm{E}+00 \\ & & & \\ \text { Total Activity: } & 1.044 \mathrm{E}+02 & 3.863 \mathrm{E}+12 & \\ \text { w/o Daughters: } & 9.401 \mathrm{E}+01 & 3.478 \mathrm{E}+12 & \\ & & & \end{array}$

Shipping Papers and Labels:

\begin{tabular}{|c|c|c|c|c|}
\hline Isotope & Number of A2s & Fraction of A2s & Cumulative A2s & Cumulative Fraction of $\mathrm{A} 2 \mathrm{~s}$ \\
\hline$A m-241$ & 626.8 & 0.4653 & 626.8 & 0.4653 \\
\hline Pu-239 & 384.9 & 0.2857 & 1012 & 0.751 \\
\hline $\mathrm{Pu}-240$ & 217.5 & 0.1615 & 1229 & 0.9125 \\
\hline $\mathrm{Pu}-238$ & 81.26 & 0.06032 & 1310 & 0.9728 \\
\hline$P u-241$ & 36.64 & 0.0272 & 1347 & 1 \\
\hline
\end{tabular}


HNF-32146, Revision 0

Appendix C

200 g Source Term Without Polyurea

Performed By: Terry Vail

Checked By: John Woodbury

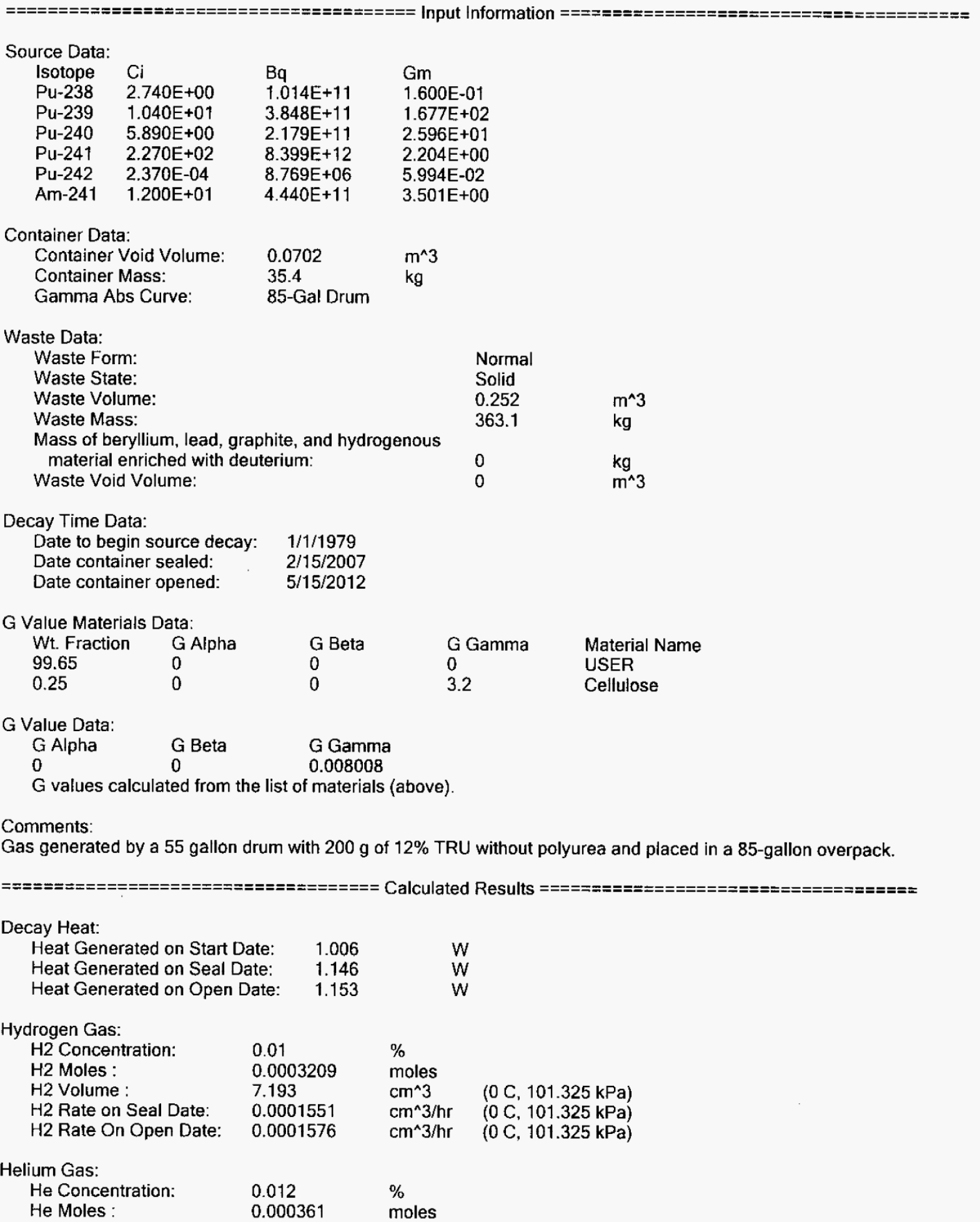

Page C-14 
HNF-32146, Revision 0

\section{Appendix C \\ 200 g Source Term Without Polyurea}

\begin{tabular}{|c|c|c|c|c|}
\hline $\begin{array}{l}\text { He Volume: } \\
\text { He Rate On Seal Date: } \\
\text { He Rate On Open Date: }\end{array}$ & $\begin{array}{l}8.091 \\
0.0001754 \\
0.0001764\end{array}$ & $\begin{array}{l}\mathrm{cm}^{\wedge} 3 \\
\mathrm{~cm}^{\wedge} 3 / \mathrm{hr} \\
\mathrm{cm} / 3 / \mathrm{hr}\end{array}$ & \multicolumn{2}{|c|}{$\begin{array}{l}(0 \mathrm{C}, 101.325 \mathrm{kPa}) \\
(0 \mathrm{C}, 101.325 \mathrm{kPa}) \\
(0 \mathrm{C}, 101.325 \mathrm{kPa})\end{array}$} \\
\hline \multicolumn{5}{|l|}{ Pressure On Open Date: } \\
\hline Partial Pressure $(\mathrm{H} 2)$ : & & 0.01038 & $\mathrm{kPa}$ & \\
\hline Partial Pressure $(\mathrm{He})$ : & & 0.01168 & $\mathrm{kPa}$ & \\
\hline Partial Pressure $(\mathrm{O} 2)$ : & & 0.00519 & $\mathrm{kPa}$ & (if $\mathrm{H} 20$ present in waste) \\
\hline Total Pressure $(\mathrm{H} 2+\mathrm{He}$ & Air): & 101.3 & $\mathrm{kPa}$ & \\
\hline Total Pressure $(\mathrm{H} 2+\mathrm{He}$ & $\mathrm{O} 2+\mathrm{Air}):$ & 101.4 & $\mathrm{kPa}$ & (if $\mathrm{H} 20$ present in waste) \\
\hline
\end{tabular}

Transportation:

Note: Calculations are made at the end of the user-specified decay time.

Radioactive Determination:

Yes

3669000

348500000

ALEC Limit Fraction:

This package is not exempt from the HMR.

Effective A2s for Mixture:

0.06979

B

1347

A2s

$(A 2 s>1.0)$

Type:

No

1347

104.4

3.863

ivity: $0.1332 \quad \mathrm{gm}$

U-235 Activity:

(ACEMs and ALECs > 1.0)

ALECS (Number of ALECs)

$\mathrm{Ci}$

mited Quantity Determination:

$\begin{array}{llll}\text { Limited Quantity: } & \text { No } & & \text { (Activity > 0.001 A2) } \\ \text { Activity: } & 1347 & \mathrm{~A} 2 & \\ & 104.4 & \mathrm{Ci} & \\ & 3.863 & \mathrm{TBq}\end{array}$

LSA Determination:
LSA-I:
No
LSA-II:
LSA-III:
Specific Activity:
No
No
$0.00371 \quad$ A2/gm
$0.0002876 \quad \mathrm{Ci} / \mathrm{gm}$
(Fissile excepted, but A2s > $30 \times$ rad limits)
(A2s/gm > 0.0001)
(A2s/gm > 0.002)

The user must check ensure that all other requirements for LSA in 49 CFR 173.403 and 49 CFR 173.427 are met.

HRCQ Determination:
HRCQ:

A2 Limit Fraction:

Activity:

No

1347

104.4

3.863

Yes

168.3

Beryllium, lead, graphite, and hydrogenous material enriched with deuterium:

Solid Non-Fissile Quantity:

Total Uranium Quantity:

U-233 Quantity:

U-235 Quantity:

Uranium Enrichment:

Total Plutonium Quantity:

Pu-239 Quantity:

Pu-241 Quantity:

\section{0}

398300

0.2403

8.212E-07

0.1332

55.45

194.2

167.6

0.5693

$\begin{array}{lll}\begin{array}{l}\text { Fissile Excepted Determination: } \\ \text { Fissile Excepted: }\end{array} & \text { Yes } & \\ \text { material > 3.365E+05 grams) } & & \\ \text { Fissile Quantity: } & 168.3 & \mathrm{gm} \\ \begin{array}{c}\text { Beryllium, lead, graphite, and } \\ \text { hydrogenous material }\end{array} & & \\ \quad \text { enriched with deuterium: } & 0 & \mathrm{gm} \\ \text { Solid Non-Fissile Quantity: } & 398300 & \mathrm{gm} \\ \text { Total Uranium Quantity: } & 0.2403 & \mathrm{gm} \\ \text { U-233 Quantity: } & 8.212 \mathrm{E}-07 & \mathrm{gm} \\ \text { U-235 Quantity: } & 0.1332 & \mathrm{gm} \\ \text { Uranium Enrichment: } & 55.45 & \mathrm{\%} \\ \text { Total Plutonium Quantity: } & 194.2 & \mathrm{gm} \\ \text { Pu-239 Quantity: } & 167.6 & \mathrm{gm} \\ \text { Pu-241 Quantity: } & 0.5693 & \mathrm{gm}\end{array}$


HNF-32146, Revision 0

\section{Appendix C \\ 200 g Source Term Without Polyurea}

\begin{tabular}{|c|c|c|c|}
\hline \multicolumn{2}{|c|}{ Container Category Determination: } & \multicolumn{2}{|l|}{ II } \\
\hline \multicolumn{4}{|c|}{ TRU Waste Determination: } \\
\hline $\begin{array}{l}\text { TRU Was } \\
\text { TRU Acti }\end{array}$ & & $\begin{array}{l}\text { Yes } \\
97450\end{array}$ & (TRU activity > $100 \mathrm{nCi} / \mathrm{gm}$ ) \\
\hline \multicolumn{4}{|c|}{ WIPP Quantities: } \\
\hline $\begin{array}{l}\text { FGE Vale } \\
\text { PE-Ci Va }\end{array}$ & & $\begin{array}{l}169.7 \\
36.33\end{array}$ & \\
\hline \multicolumn{4}{|c|}{ Reportable Quantity Determination: } \\
\hline Reportab & lity: & Yes & (RQs > = 1.0) \\
\hline RQ Limit & & 3607 & (Number of RQs) \\
\hline \multicolumn{4}{|c|}{ Dose-Equivalent Curies: } \\
\hline Total ICR & DE-Ci: & 33.55 & \\
\hline Total FGI & -Ci: & 36.82 & \\
\hline \multicolumn{4}{|c|}{ Source at the Start of Seal Time: } \\
\hline Isotope & $\mathrm{Ci}$ & $\mathrm{Bq}$ & $\mathrm{Gm}$ \\
\hline $\mathrm{Hg}-206$ & $3.823 \mathrm{E}-19$ & $1.414 \mathrm{E}-08$ & 3.413E-27 \\
\hline Ti-206 & $2.687 \mathrm{E}-17$ & $9.942 \mathrm{E}-07$ & 1.236E-25 \\
\hline $\mathrm{TI}-207$ & $2.043 E-11$ & $7.558 \mathrm{E}-01$ & $1.073 \mathrm{E}-19$ \\
\hline TI-208 & $5.563 \mathrm{E}-16$ & $2.058 \mathrm{E}-05$ & $1.880 \mathrm{E}-24$ \\
\hline TI-209 & $1.442 \mathrm{E}-13$ & $5.335 \mathrm{E}-03$ & $3.526 \mathrm{E}-22$ \\
\hline TI-210 & $2.258 \mathrm{E}-14$ & 8.356E-04 & $3.279 \mathrm{E}-23$ \\
\hline $\mathrm{Pb}-209$ & $6.676 \mathrm{E}-12$ & $2.470 \mathrm{E}-01$ & $1.448 \mathrm{E}-18$ \\
\hline Pb-210 & $2.012 \mathrm{E}-11$ & 7.444E-01 & $2.635 \mathrm{E}-13$ \\
\hline $\mathrm{Pb}-211$ & $2.048 \mathrm{E}-11$ & 7.578E-01 & $8.297 \mathrm{E}-19$ \\
\hline $\mathrm{Pb}-212$ & $1.548 \mathrm{E}-15$ & 5.727E-05 & 1.114E-21 \\
\hline $\mathrm{Pb}-214$ & $1.075 \mathrm{E}-10$ & $3.978 \mathrm{E}+00$ & $3.280 \mathrm{E}-18$ \\
\hline $\mathrm{Bi}-210$ & $2.007 \mathrm{E}-11$ & $7.425 \mathrm{E}-01$ & $1.618 \mathrm{E}-16$ \\
\hline $\mathrm{Bi}-211$ & $2.048 \mathrm{E}-11$ & 7.578E-01 & 4.987E-20 \\
\hline $\mathrm{Bi}-212$ & $1.548 \mathrm{E}-15$ & 5.727E-05 & 1.057E-22 \\
\hline $\mathrm{Bi}-213$ & $6.676 \mathrm{E}-12$ & $2.470 E-01$ & $3.448 \mathrm{E}-19$ \\
\hline Bi-214 & $1.075 \mathrm{E}-10$ & $3.979 E+00$ & $2.436 \mathrm{E}-18$ \\
\hline $\mathrm{Bi}-215$ & $1.665 \mathrm{E}-17$ & $6.159 E-07$ & $1.408 \mathrm{E}-25$ \\
\hline Po-210 & $1.866 \mathrm{E}-11$ & $6.904 \mathrm{E}-01$ & 4.153E-15 \\
\hline Po-211 & $5.592 \mathrm{E}-14$ & $2.069 \mathrm{E}-03$ & $5.396 \mathrm{E}-25$ \\
\hline Po-212 & $9.914 \mathrm{E}-16$ & 3.668E-05 & $5.589 \mathrm{E}-33$ \\
\hline Po-213 & $6.533 \mathrm{E}-12$ & 2.417E-01 & $5.180 \mathrm{E}-28$ \\
\hline Рo-214 & $1.075 \mathrm{E}-10$ & $3.978 \mathrm{E}+00$ & 3.365E-25 \\
\hline Po-215 & $2.048 \mathrm{E}-11$ & 7.579E-01 & $6.948 \mathrm{E}-25$ \\
\hline Po-216 & $1.548 \mathrm{E}-15$ & $5.728 \mathrm{E}-05$ & $4.298 \mathrm{E}-27$ \\
\hline Po-218 & $1.075 \mathrm{E}-10$ & $3.979 E+00$ & $3.803 E-19$ \\
\hline At-215 & 8.193E-17 & 3.031E-06 & $1.561 \mathrm{E}-31$ \\
\hline At-217 & 6.677E-12 & $2.470 \mathrm{E}-01$ & 4. $148 \mathrm{E}-24$ \\
\hline At-218 & $2.151 \mathrm{E}-14$ & $7.958 \mathrm{E}-04$ & $6.650 \mathrm{E}-25$ \\
\hline At-219 & $1.716 \mathrm{E}-17$ & 6.349E-07 & 1.799E-26 \\
\hline Rn-217 & $8.012 \mathrm{E}-16$ & $2.965 \mathrm{E}-05$ & $8.322 E-30$ \\
\hline$R n-218$ & $2.151 \mathrm{E}-17$ & 7.958E-07 & 1.455E-29 \\
\hline $\mathrm{Rn}-219$ & $2.048 \mathrm{E}-11$ & 7.579E-01 & $1.575 E-21$ \\
\hline$R n-220$ & $1.548 \mathrm{E}-15$ & $5.728 \mathrm{E}-05$ & 1.679E-24 \\
\hline $\mathrm{Rn}-222$ & $1.075 \mathrm{E}-10$ & $3.979 E+00$ & $6.994 \mathrm{E}-16$ \\
\hline Fr-221 & $6.677 \mathrm{E}-12$ & $2.470 \mathrm{E}-01$ & $3.846 \mathrm{E}-20$ \\
\hline $\mathrm{Fr}-223$ & $2.860 \mathrm{E}-13$ & $1.058 \mathrm{E}-02$ & $7.395 \mathrm{E}-21$ \\
\hline Ra-223 & $2.048 \mathrm{E}-11$ & 7.579E-01 & $3.999 \mathrm{E}-16$ \\
\hline Ra-224 & $1.548 \mathrm{E}-15$ & $5.728 \mathrm{E}-05$ & $9.615 \mathrm{E}-21$ \\
\hline$R a-225$ & $6.706 \mathrm{E}-12$ & $2.481 \mathrm{E}-01$ & 1.710E-16 \\
\hline $\mathrm{Ra}-226$ & $1.077 \mathrm{E}-10$ & $3.985 E+00$ & $1.090 \mathrm{E}-10$ \\
\hline $\mathrm{Ra}-228$ & $1.965 \mathrm{E}-15$ & $7.271 \mathrm{E}-05$ & $7.208 E-18$ \\
\hline$A C-225$ & $6.677 \mathrm{E}-12$ & $2.470 \mathrm{E}-01$ & 1.151E-16 \\
\hline
\end{tabular}


HNF-32146, Revision 0

\section{Appendix C \\ $200 \mathrm{~g}$ Source Term Without Polyurea}

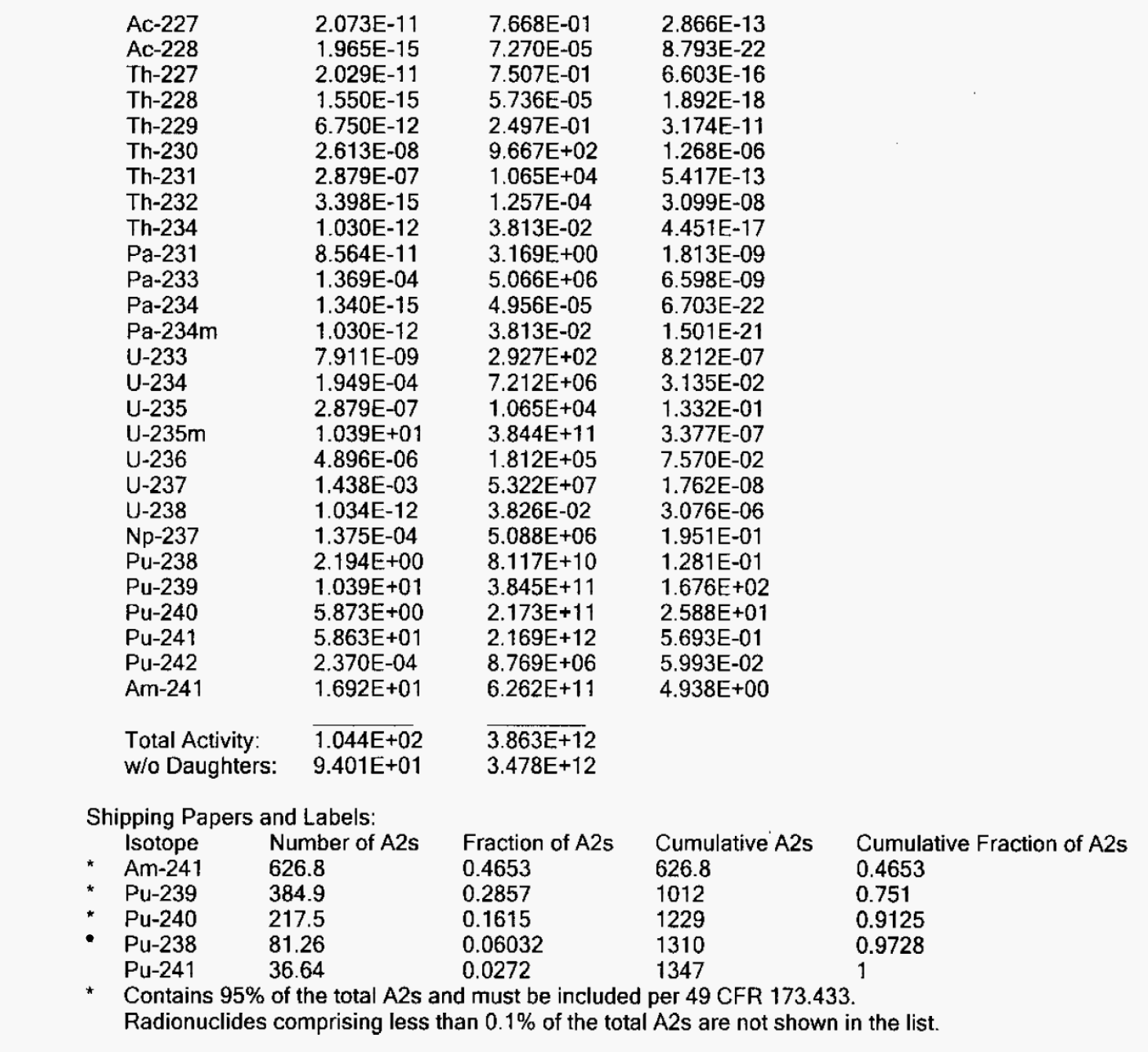

Page $\mathrm{C}-17$

